\title{
CONDICIONAMENTO FISIOLÓGICO DE SEMENTES DE SOJA: EFEITOS SOBRE A GERMINAÇÃO, VIGOR E POTENCIAL DE ARMAZENAMENTO
}

\author{
GISELE HERBST VAZQUEZ \\ Engenhei ro Agrônomo \\ Orientador: Prof. Dr. JÚlio MARCOS FILHO
}

Dissertação apresentada à Escola Superior de Agricultura "Luiz de Queiroz", da Universidade de São Paulo, para obtenção do título de Mestre em Agronomia, Área de Concentração: Fitotecnia.

PIRACICAB A

Estado de São Paulo - Brasil

Março - 1995 
catalOgAGGO Ha PUBLICAGGAO

divisáo de biblioteca e docUMEHTAĢ̃o - CAMPUS "LUIZ de QUEIROZ"/USP

Vazquez, Gisele Herbst

V335c Condicionamento fisiológico de sementes de soja: efeitos sobre a germinação, vigor e potencial de armazenamento. Piracicaba, 1995.

138p. ilus.

Diss.(Mestre) - ESALQ

Bibliografia.

1. Soja - Semente - Armazenamento 2. Soja - Semente - Tratamento 3. Soja Semente - Vigor I, Escola Superior de Agricultura Luiz de Queiroz, Piracicaba

$\operatorname{coD} \quad 633.34$ 


\section{CONDICIONAMENTO FISIOLÓGICO DE SEMENTES DE SOJA: EFEITOS SOBRE A GERMINAÇÃO, VIGOR E POTENCIAL DE ARMAZENAMENTO}

GISELE HERBST VAZQUEZ

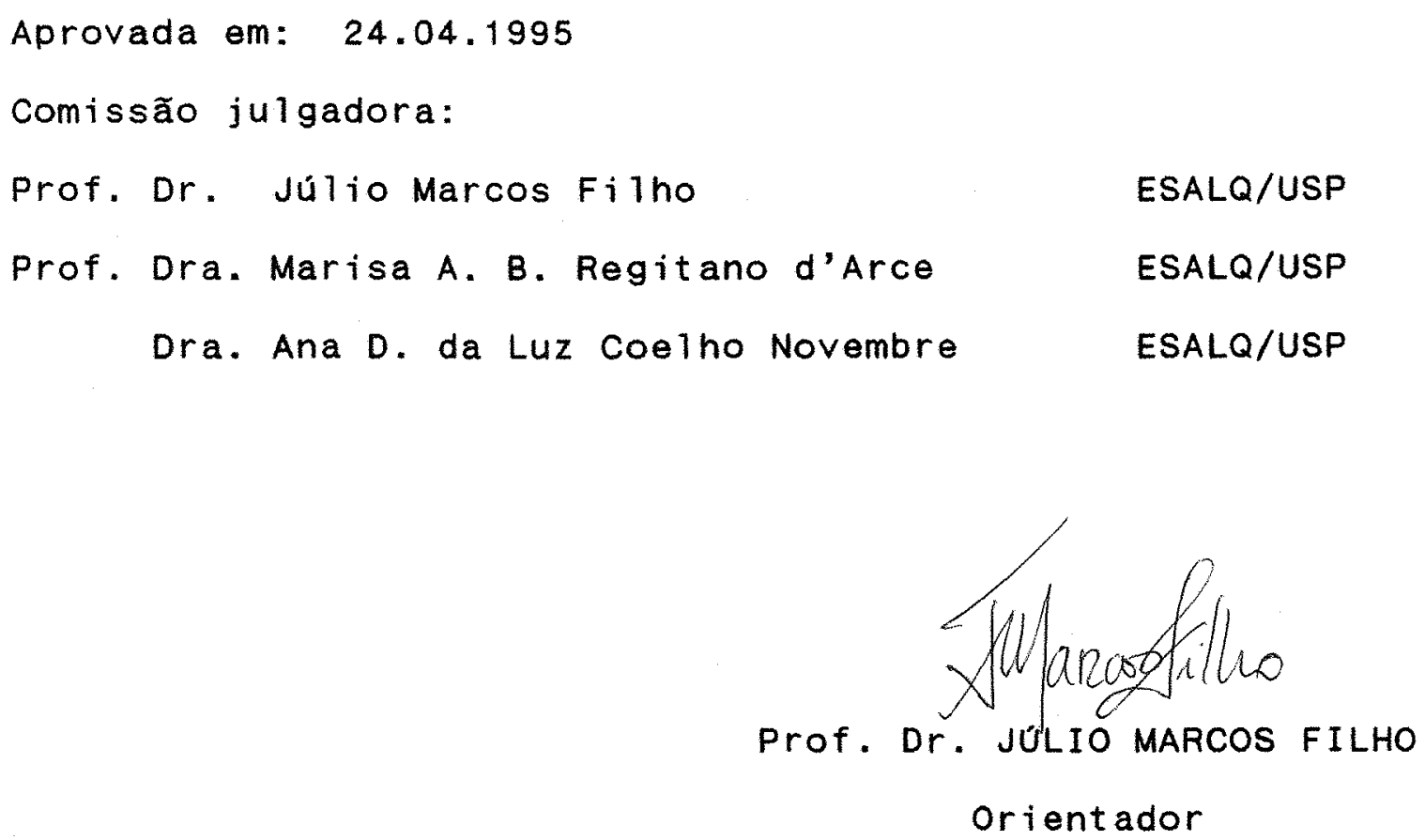


"E necessário correr o máximo possivel para ficar no mesmo lugar. se você quer chegar a algum outro lugar, deve correr pelo menos duas vezes mais rápido do que isso!"

Lewis Carrol

Ao Rogério, Guilherme e à minha família pelo incentivo nesta corrida. 


\section{AGRADECIMENTOS}

Ao Professor Júlio Marcos Filho, pela amizade, apoio, orientação e estímulo para meu ingresso como "sementeira".

A Professora Marisa A. B. Regitano d'Arce, pela amizade, orientação e sugestões na condução deste trabalho.

Ao Professor Walter Rodrigues da Silva, pela constante assistência e amizade.

Aos Professores Francisco Ferraz de Toledo e Silvio Moure Cícero, pelo apoio e incentivo.

As Engenheiras Agrônomas Helena M. P. Chamma e Ana D. C. Novembre, pela compreensão, carinho e auxilio constante.

A Professora Maria Cristina stolf Nogueira pela orjentação na análise estatistica.

A Engenheira Agrônoma Maria Heloísa Duarte de Moraes pelo auxilio na realização dos testes de sanidade.

As colegas Denise C. S. dos Santos Dias, Maria Laene M. de Carvalho, Ceci C. Custódio, Maria Angela A. Tillmann e Maria Cristina M. Spinola pela amizade e incentivo.

A Maria Fernanda de Almeida Prado do Departamento de Ciência Tecnologia Agroindustrial pela realização das análises de composição química e amizade.

Aos estagiários Marcelo C. Petto e Laís T. Furusho pela colaboração na execução dos testes de laboratório.

Aos Funcionários do Departamento de Agricultura da ESALQ/USP pela colaboração prestada.

Ao Conselho Nacional de Desenvolvimento Cientifico $e$ Tecnológico pela concessão da Bolsa de Estudos. 
SUMARIO

Página

LISTA DE FIGURAS $\ldots \ldots \ldots \ldots \ldots \ldots \ldots \ldots \ldots \ldots \ldots \ldots \ldots$

LISTA DE TABELAS $\ldots \ldots \ldots \ldots \ldots \ldots \ldots \ldots \ldots \ldots \ldots \ldots \ldots \ldots \ldots \ldots$

RESUMO $\ldots \ldots \ldots \ldots \ldots \ldots \ldots \ldots \ldots \ldots \ldots \ldots \ldots \ldots \ldots \ldots \ldots \ldots$

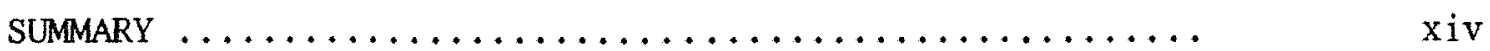

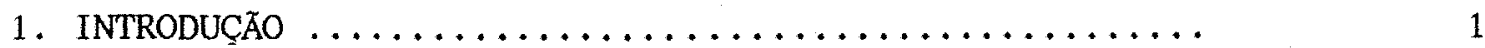

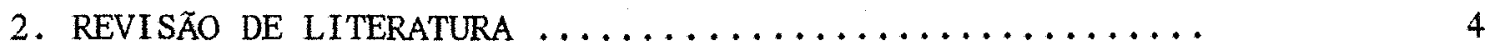

2.1. Deterioração de Sementes $\ldots \ldots \ldots \ldots \ldots \ldots \ldots \ldots \ldots$ 4 4

2.2. Fases da Germinação $\ldots \ldots \ldots \ldots \ldots \ldots \ldots \ldots \ldots \ldots$

2.3. Reversibilidade da Deterioração $\ldots \ldots \ldots \ldots \ldots \ldots$

2.4. Condicionamento Fisiológico ............. 29

3. MATERIAL E MEtTDDos $\ldots \ldots \ldots \ldots \ldots \ldots \ldots \ldots \ldots \ldots \ldots \ldots$

3.1. Caracterização dos Lotes $\ldots \ldots \ldots \ldots \ldots \ldots \ldots \ldots \ldots$

3.2. Obtenção dos Tratamentos $\ldots \ldots \ldots \ldots \ldots \ldots \ldots \ldots$

3.3. Avaliação dos Efeitos dos Tratamentos ......... 60

3.4. Procedimento Estatístico $\ldots \ldots \ldots \ldots \ldots \ldots \ldots \ldots$

4. RESULTADOS E DISCUSSÃO $\ldots \ldots \ldots \ldots \ldots \ldots \ldots \ldots \ldots \ldots$

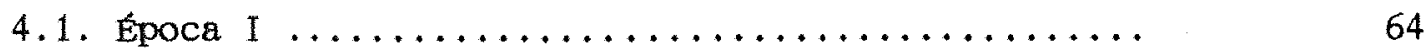

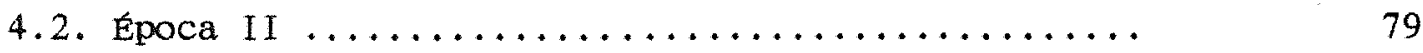

4.3. Epoca III $\ldots \ldots \ldots \ldots \ldots \ldots \ldots \ldots \ldots \ldots \ldots \ldots$

4.4. Composição Química .................. 92

4.5. Considerações Gerais $\ldots \ldots \ldots \ldots \ldots \ldots \ldots \ldots \ldots \ldots$

5. CONCLUSÕES $\ldots \ldots \ldots \ldots \ldots \ldots \ldots \ldots \ldots \ldots \ldots \ldots \ldots \ldots \ldots \ldots \ldots$

REFERENCIAS BIBLIOGRAFICAS $\ldots \ldots \ldots \ldots \ldots \ldots \ldots \ldots \ldots \ldots \ldots$ 
LISTA DE FIGURAS

Figura

Página

1. Características estruturais das membranas celulares (In: BEWLEY, 1973) .............

2. Modelo de mosaico fluido proposto por SINGER \& NICOLSON $(1972) \ldots \ldots \ldots \ldots \ldots \ldots \ldots \ldots \ldots$

3. Padrão trifásico de absorção de água por sementes em germinação (In: BEWLEY \& BLACK, 1983) .......

4. Representação esquemática das fases de deterioração, ativação e reparo, e germinação de sementes em diferentes níveis de água (In: HEGARTY, $1977 b) \ldots \ldots \ldots \ldots \ldots \ldots \ldots \ldots \ldots$

5. Modificações bioquímicas em sementes de algodão durante a fase de embebição do processo de germinação (In: PERL, 1979) .............. 
1. Caracterização dos lotes de sementes de soja (Glycine $\max$ (L.) Merril), cultivar IAC-8 ......

2. Tratamentos empregados $\ldots \ldots \ldots \ldots \ldots \ldots \ldots$

3. Esquema de análise de variância dos dados obtidos nos testes de avaliação da qualidade fisiológica das sementes para cada época ..............

4. Esquema de análise da variância dos dados de composição química $\ldots \ldots \ldots \ldots \ldots \ldots \ldots \ldots \ldots$

5. Grau de umidade: valores médios (\%) obtidos para os quatro lotes de sementes de soja após os tratamentos de condicionamento fisiologico. Piracicaba, $1992 \ldots \ldots \ldots \ldots \ldots \ldots \ldots \ldots \ldots$

6. Significâncias do Teste $F$ referentes às determinações para a avaliação do desempenho das sementes logo após o condicionamento fisiológico. Piracicaba, $1992 \ldots \ldots \ldots \ldots \ldots \ldots \ldots \ldots$

7. Germinação e envel hecimento acelerado: comparação de valores médios de lotes e tratamentos após condicionamento fisiologico (sementes ainda úmidas). Piracicaba, $1992 \ldots \ldots \ldots \ldots \ldots \ldots \ldots \ldots$ 
8. Condutividade elétrica e emergência das plântulas em campo: comparação de valores médios de lotes e tratamentos após condicionamento fisiológico (sementes ainda úmidas). Piracicaba, $1992 \ldots .$. .

9. Grau de umidade: valores médios (\%) obtidos para os quatro lotes de sementes de soja submetidos a secagem ao ar após o condicionamento fisiológico. Piracicaba $1992 \ldots \ldots \ldots \ldots \ldots \ldots \ldots \ldots \ldots \ldots$

10. Significâncias do Teste $F$ referentes às determinações para a avaliação do desempenho das sementes de soja submetidas a secagem ao ar logo após o condicionamento fisiológico. Piracicaba, 1992

11. Germinação e envelhecimento acelerado: comparação de valores médios de lotes e tratamentos de sementes de soja submetidas a secagem ao ar logo após o condicionamento fisiológico. Piracicaba, 1992

12. Condutividade elétrica e emergência das plântulas em campo: comparação de valores médios de lotes e tratamentos de sementes de soja submetidas a secagem ao ar logo após o condicionamento fisiologico. Piracicaba, $1992 \ldots \ldots \ldots \ldots \ldots \ldots$

13. Grau de umidade: valores médios (\%) obtidos para os quatro lotes de sementes de soja condicionadas por três meses. Piracicaba, $1992 \ldots \ldots \ldots \ldots \ldots$. 
14. Significâncias do Teste $F$ referentes às determinações para a avaliação do desempenho de sementes de soja submetidas ao condicionamento fisiológico, secas ao ar e posteriormente armazenadas por três meses. Piracicaba, 1992 ...

15. Germinação e envelhecimento acelerado: comparação de valores médios de lotes e tratamentos de sementes de soja armazenadas por três meses após o condicionamento fisiológico e a secagem. Piracicaba, $1992 \ldots \ldots \ldots \ldots \ldots \ldots \ldots \ldots \ldots \ldots$

16. Condutividade elétrica e emergência das plântulas em campo: comparação de valores médios de lotes e tratamentos de sementes de soja armazenadas por três meses após o condicionamento fisiológico e a secagem. Piracicaba, $1992 \ldots \ldots \ldots \ldots \ldots \ldots \ldots$

17. Grau de umidade: valores médios (\%) obtidos para os quatro lotes de sementes de soja condicionadas e armazenadas por seis meses. Piracicaba, 1993.

18. Significâncias do Teste $F$ referentes às determinações para a avaliação do desempenho de sementes de soja submetidas ao condicionamento fisiológico, secas ao ar e posteriormente armazenadas por seis meses. Piracicaba, 1993 ... 
19. Germinação e envelhecimento acelerado: comparação de valores médios de lotes e tratamentos de sementes de soja armazenadas por seis meses após - condicionamento fisiológico e secagem. Piracicaba, $1993 \ldots \ldots \ldots \ldots \ldots \ldots \ldots \ldots \ldots \ldots$

20. Condutividade elétrica e emergência das plântulas em campo: comparação de valores médios de lotes e tratamentos de sementes de soja armazenadas por seis meses após o condicionamento fisiológico e a secagem. Piracicaba, $1993 \ldots \ldots \ldots \ldots \ldots \ldots \ldots \ldots$

21. Significâncias do Teste $F$ referentes às determinações para a avaliação da composição química das sementes durante o experimento. Piracicaba, 1992/93 .....................

22. Teor de óleo (\% m.s.): comparação de valores médios de lotes, tratamentos e épocas de sementes de soja condicionadas fisiologicamente, posteriormente secas em ambiente natural e finalmente armazenadas por 6 meses. Piracicaba,

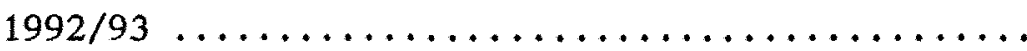

23. Indice de acidez (mg $\mathrm{KOH} / \mathrm{g}$ ): comparação de valores médios de lotes, tratamentos e épocas de sementes de soja condicionadas fisiologicamente, posteriormente secas em ambiente natural e finalmente armazenadas por 6 meses. Piracicaba,

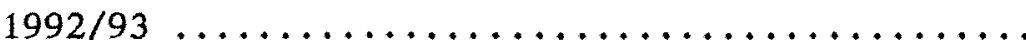


24. Indice de peróxido (meq $\mathrm{O}_{2} / 1000 \mathrm{~g}$ ): comparação de valores médios de lotes, tratamentos e épocas de sementes de soja condicionadas fisiologicamente, posteriormente secas em ambiente natural e finalmente armazenadas por 6 meses. Piracicaba,

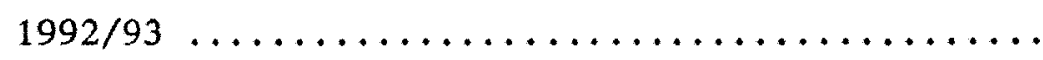

25. Proteína bruta (\% m.s.): comparação de valores médios de lotes, tratamentos e épocas de sementes de soja condicionadas fisiologicamente, posteriormente secas em ambiente natural e finalmente armazenadas por 6 meses. Piracicaba, $1992 / 93 \ldots \ldots \ldots \ldots \ldots \ldots \ldots \ldots \ldots \ldots \ldots \ldots$

26. Açúcares totais $(\mathrm{mg} / \mathrm{g})$ : comparação de valores médios de lotes, tratamentos e épocas de sementes de soja condicionadas fisiologicamente, posteriormente secas em ambiente natural e finalmente armazenadas por 6 meses. Piracicaba,

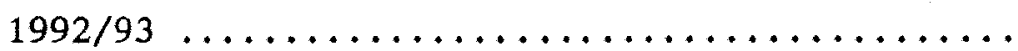

27. Açúcares redutores ( $\mathrm{mg} / \mathrm{g}$ ): comparação de valores médios de lotes, tratamentos e épocas de sementes de soja condicionadas fisiologicamente, posteriormente secas em ambiente natural e finalmente armazenadas por 6 meses. Piracicaba, $1992 / 93 \ldots \ldots \ldots \ldots \ldots \ldots \ldots \ldots \ldots \ldots \ldots \ldots . \ldots \ldots \ldots$ 


\title{
CONDICIONAMENTO FISIOLÓGICO DE SEMENTES DE SOJA: EFEITOS SOBRE A GERMINAÇÃO, VIGOR E POTENCIAL DE ARMAZENAMENTO
}

\author{
Autor: GISELE HERBST VAZQUEZ \\ Orientador: Prof. Dr. JÚLIO MARCOS FILHO
}

RESUMO

- estabelecimento das plântulas no campo é reconhecido como uma fase crucial da cultura da soja. Vários estudos têm sido realizados com o objetivo de reduzir ou evitar a exposição prolongada das sementes a condições adversas que possam causar deterioração prematura em campo. Um dos tratamentos considerados mais promissores é o condicionamento fisiologico.

Assim, o presente trabalho, conduzido nos Laboratórios de Análise de sementes e de Tecnologia Agroindustrial da Escola Superior de Agricultura "Luiz de Queiroz", da Universidade de são Paulo, Brasil, teve por objetivo estudar os efeitos do condicionamento fisiológico de sementes de soja sobre a germinação, vigor e potencial de armazenamento.

Para tanto, sementes de 4 lotes de soja do cultivar IAC-8 foram submetidas à hidratação lenta durante periodos de 12,18 e 24 horas a $20^{\circ} \mathrm{C}$, seguida por secagem 
natural até o teor de água original. Paralelamente, foi efetuado o condicionamento osmótico a $20^{\circ} \mathrm{C}$, durante 4 dias com embebição em solução de polietileno glicol (PEG 6000), com potenciais hidricos de -6 e -8 atm; as sementes submetidas a estes tratamentos também sofreram secagem.

As sementes condicionadas fisiologicamente foram avaliadas ainda úmidas, logo após a secagem e depois de armazenadas por 3 e 6 meses, em condições normais de ambiente de laboratório, além da testemunha não condicionada. As determinações constaram do teste de germinação, envelhecimento acelerado, condutividade elétrica, emergência das plântulas em campo, grau de umidade e composição química das sementes através das determinações de teor de oleo, indice de acidez, indice de peróxido, proteina bruta, açúcares totais solúveis em álcool e açúcares redutores.

A análise dos dados e interpretação dos resultados, nas condições do presente trabalho, permitiram concluir que:

1. O condicionamento fisiológico proporciona beneficios imediatos ao desempenho de sementes de soja, mas os mesmos são revertidos com a posterior secagem e o armazenamento.

2. A embebição controlada, sem o uso de substâncias químicas (hidratação lenta) e o condicionamento osmótico fornecem resultados semeinantes.

3. Dentro dos limites estudados, a melhor resposta ao condicionamento fisiologico é proporcional ao nivel de umidade empregado. 


\title{
PHYSIOLOGICAL CONDITIONING OF SOYBEAN SEEDS: EFFECTS ON GERMINATION, VIGOUR AND STORAGE POTENTIAL
}

\author{
Author: GISELE HERBST VAZQUEZ \\ Adviser: Prof. Dr. JÚLIO MARCOS FILHO
}

SUMMARY

The plant field establishment is recognized as critical soybean seed development phase. Several studies have been carried out with the purpose of reducing or avoiding a long soybean seeds exposure to adverse conditions which may cause premature damage in the field. The physiological conditioning is one of the most considerable and promising treatments.

This research conducted at the seed Analysis and the Food Technology Laboratories of the Escola Superior de Agricultura Luiz de Queiroz, University of São Paulo, Brasil, had the main purpose of studying the soybean seeds physiological conditioning effects on germination, vigour and storage potential.

The seeds from four soybean lots IAC- 8 were submitted to a slow hydration for periods of 12,18 and 24 hours at $20^{\circ} \mathrm{C}$, followed by a natural air drying up process to 
the original water content. Along with that, the osmotic conditioning was performed at $20^{\circ} \mathrm{C}$ during four days of imbibition in a polyethylene glycol solution (PEG 6000) with hydric potentials of -6 and -8 atm. The seeds from this treatment also underwent a natural air drying process.

The physiologically conditioned seeds plus the control samples were evaluated when humid, shortafter drying and after storage for 3 and 6 months at ambient temperatures. Laboratory determinations consisted of germination tests, seed moisture, accelerated ageing, electric conductivity and seedling emergence. The chemical composition of the seeds was determined by the oil content, oil acid and peroxide values, brute protein content, total alcohol soluble sugar and reducing sugar contents.

The data analysis and the result interpretation under the present work conditions led to the following conclusions:

1. The physiological conditioning provides immediate benefits to the soybean seeds development but they seem to be reversible after drying and storage.

2. The controlled imbibition without using chemical substances and the osmotic conditioning provided similar effects.

3. Within the limits of this study, moisture content determines the efficiency of physiological conditioning. 


\section{INTRODUÇÃO}

A base da alta produção por área depende diretamente do sucesso do estabelecimento das plantas no campo que, por sua vez, reflete o manejo racional e da qualidade das sementes utilizadas. O desempenho das sementes está relacionado ao histórico de sua produção e processamento e às condições de ambiente que encontra no solo; assim, não são raras as observações quanto ao comportamento deficiente de lotes após a semeadura, refletindo as dificuldades encontradas pelas sementes quando expostas a estresses.

Em consequência desses fatos e da debilidade natural das sementes de soja, de natureza morfológica e fisiológica, inúmeros pesquisadores têm concentrado esforços com o objetivo de atenuar ou de solucionar problemas, dirigindo estudos ao controle de qualidade, deterioração, colheita, armazenamento e tratamento de sementes, em benefício do seu comportamento após a semeadura.

Um dos procedimentos mais promissores é o tratamento pré-semeadura, envolvendo a iniciação do metabolismo de germinação, através do controle da absorção de 
água pela semente sem, no entanto, permitir a protrusão da raiz primária. A hidratação das sementes pode ser efetuada mediante exposição à atmosfera úmida, embebição em substrato úmido e imersão em soluções osmóticas; esse tratamento pode ser contínuo, até que as sementes atinjam o grau de umidade programado, ou envolver ciclo(s) hidratação/secagem. Este processo tem sido citado através de denominações como "endurecimento", "priming", "envigoramento", "condicionamento osmótico" e "condicionamento fisiológico".

De um modo geral, os resultados obtidos após os ciclos hidratação/secagem têm sido semelhantes aos provenientes do condicionamento osmótico com o uso de produtos químicos. No entanto, há autores que apontam vantagens de um ou de outro procedimento; essas observações ainda não podem ser consideradas definitivas e devem ser avaliadas em novas pesquisas porque os trabalhos sobre o assunto não têm envolvido comparações diretas entre esses métodos.

Outros aspectos controvertidos são referentes ao comportamento de sementes submetidas a secagem após condicionamento e reversão dos efeitos do tratamento em sementes armazenadas. O desempenho de amostras de sementes de soja, com diferentes qualidades fisiológicas, quando condicionadas e submetidas a testes de vigor, as possíveis diferenças entre os efeitos do condicionamento com soluções osmóticas e os da hidratação controlada e as transformaçôes 
bioquímicas nas sementes, são aspectos que necessitam informações adicionais porque ainda não foram totalmente elucidados.

Desta maneira, o presente trabalho foi planejado e conduzido com o objetivo de obter subsídios que permitam auxiliar o esclarecimento dessas dúvidas. 


\section{REVISÃO DE LITERATURA}

\subsection{Deterioração de Sementes}

o envelhecimento, em todos os organismos vivos, é a soma dos processos deteriorativos que, em consequência, levam à morte (MATTHEWs, 1985). O processo de deterioração consiste numa série de transformações físicas, químicas, fisiológicas e morfológicas, que ocorrem após a maturidade e conduzem à perda da qualidade da semente.

Segundo TOLEDO \& MARCOS FILHO (1977), o termo deterioração implica numa alteração degenerativa irreversível na qualidade de uma semente, depois que esta atingiu seu ponto de máxima qualidade. No entanto, esse "máximo de qualidade" nem sempre é elevado, porque muitos fatores contribuem para prejudicar o desenvolvimento das sementes, em condições de campo como, por exemplo, deficiências minerais ou elementos tóxicos do solo, pragas e doenças, condições adversas de clima e tratos culturais ineficientes.

Para DELOUCHE (1968), a deterioração é

"inexorável, irreversível e mínima na maturidade; seu 
progresso é variável entre as espécies, entre lotes de sementes da mesma espécie e entre sementes do mesmo lote". A análise da deterioração das sementes pode ser feita através de suas características:

\section{a. Processo progressivo}

BANERJEE (1978), trabalhando com sementes de cevada e cebola, constatou que a deterioraça de uma semente inicia-se nas extremidades do eixo embrionário (plúmula e radícula) e caminha em direção à porção mediana. CHAUHAN (1985), utilizando sementes de soja e cevada, confirmou esses dados, verificando que os tecidos de reserva são os mais resistentes à deterioração. A velocidade de deterioração depende do cultivar em questão, do manejo empregado e do ambiente durante a colheita e o armazenamento. Segundo CARVAlHo (1994), essa sistemática de progressão da deterioração nos tecidos de uma semente depende da causa concreta da deterioração. Quando essa causa for dano mecânico ou por inseto, o ponto inicial da deterioração será onde o dano ocorreu. Já para as outras, como retardamento de colheita, secagem mal feita e armazenamento inadequado é provável que a deterioração se dê a partir das extremidades do eixo embrionario.

\section{b. Inexoráve 1}

Os organismos vivos, conforme relatou POPINIGIS (1977), envelhecem e morrem e, embora a 
deterioração seja inevitável, a sua velocidade poderá, até certo ponto, ser controlada pelo emprego de técnicas adequadas de colheita, secagem, beneficiamento, manuseio e armazenamento.

\section{c. Irreversíve 1}

Após a morte da semente, é impossível revivêla (POPINIGIS, 1977), ou seja, a partir do momento em que o processo se inicia não podemos retornar a uma condição anterior. Trabalhos atuais contestam essa irreversibilidade da deterioração, já que o uso de fungicidas pode conferir proteção às sementes até um determinado período, a partir do qual a deterioração fisiologica aumentaria, resultando em perda de viabilidade (FRANÇA NETO et al., 1985 e PESKE \& DELOUCHE, 1985). Através do tratamento de sementes antes da semeadura é possível a obtenção de estandes adequados, mesmo com a utilização de sementes de vigor médio e/ou quando a semeadura é efetuada em solos com baixa disponibilidade hídrica e/ou ainda, em solos com baixa temperatura (HENNING et a1., 1992).

Outras técnicas conduzem a uma melhoria no desempenho das sementes ou, até mesmo, a uma reversão no processo de deterioração. São de forma geral, denominadas pré-condicionamento fisiológico (KHAN et al., 1976) e atuam através do controle da hidratação. Inúmeros trabalhos relataram ser possível o "revigoramento" ou melhoria do desempenho da semente através dessa técnica (HEYDECKER et 
a1., 1975; HEYDECKER \& COOLBEAR, 1977; SAVINO et al., 1979; KNYPL \& KHAN, 1981; WARD \& POWELL, 1983; BURGASS \& POWELL, 1984; TILDEN \& WEST, 1985; CHIMMAD et al., 1987; DEY PATHAK \& MUKHERJEE, 1988; FU et a $1 ., 1988$; PANDEY, 1988; PANDEY, 1989 ; SAHA et a 1., 1990; WANG \& ZHAO, 1990 e NATH et al., $1991)$.

A deterioração nas sementes se manifesta através de várias alterações bioquímicas ou metabólicas e fisiológicas. O processo de envelhecimento, cuja causa básica ainda não é bem conhecida, teria como alteração bioquímica inicial a desestruturação de sistemas de membranas ao nível celular (KOOSTRA \& HARRINGTON, 1973). A causa imediata dessa destruturação seria a ação de grupos químicos de alta reatividade e que recebem o nome de radicais livres. o processo pelo qual os radicais livres se formam através da atividade metabólica da célula é consequência da reação de lipídios estruturais (lipídios que compõem a membrana celular), principalmente os polinsaturados, razão pela qual esse processo é designado como peroxidação de lipídios (WILSON Jr. \& MCDONALD Jr., 1986).

As membranas celulares, de acordo com descrição de BEWLEY (1973), seriam constituídas de uma camada dupla de moléculas de lipídios às quais se associariam, interna e externamente, moléculas de proteínas, conforme mostra a Figura 1. 


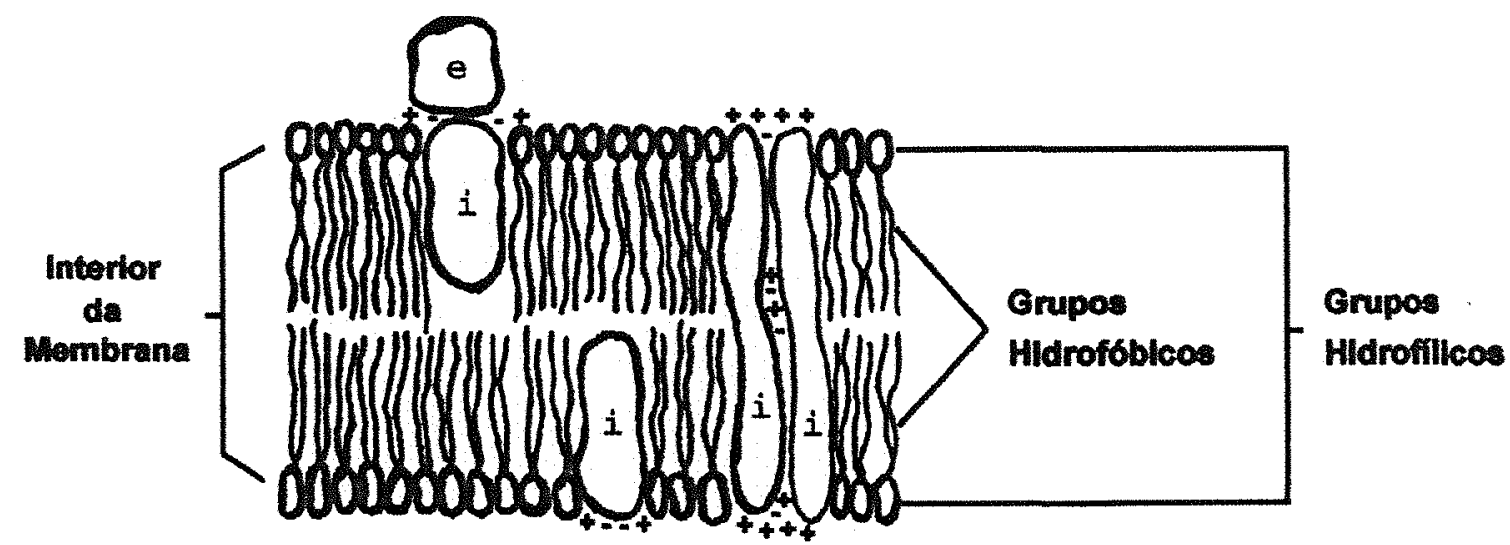

(i) - proteína intrínseca (fica dentro da camada dupla)

(e) - proteína extrínseca (só se relaciona com a superfície da membrana)

Figura 1 - Características estruturais das membranas celulares (In: BEWLEY, 1973).

o termo membrana, descrito como uma estrutura trilaminar, com aproximadamente 75 a $90 \AA$ de espessura consiste de uma camada de lipídio, a superfície polar, que é coberta por monocamadas de proteínas. Corpúsculos de Golgi, retículo endoplasmático, peroxissomas e glioxissomas são estruturas limitadas por membrana única. Plastídeos, mitocôndrias e núcleo são limitados por membranas duplas ou envelopes. Esferossomas têm como limite uma membrana, ribossomas e polissomas não são limitados por membranas (ABDUL - BAKI \& BAKER, 1973).

A camada dupla age como uma barreira à difusão geral de materiais para o interior e exterior das células e organelas, além de providenciar um meio adequado para que 
proteínas mensageiras transmembranais funcionem (MATTHEWS, 1985).

Os principais constituintes da camada dupla de lipídios são os chamados lipídios polares, dos quais os mais abundantes são os fosfolipídios do tipo fosfatil colina, fosfatidil elanolamina e fosfatidil inositol. Esses lipídios são chamados polares, por apresentarem-se como moléculas, cujas extremidades demonstram comportamentos opostos em relação à afinidade por água. Numa extremidade está situado o grupo principal e que é hidrofilico; na outra, estão situados ácidos graxos de cadeias longas, que se constituem no grupo hidrofóbico. Unidos, esses dois grupos formam o que se chama de lipídio polar. Na presença de água, esses lipídios se unem de forma que os grupos hidrofilicos ficam voltados para a água e os hidrofóbicos do lado oposto ao da água. Dessa forma, os lipídios se arranjam em uma configuração lamelar, do que resulta a membrana (MATTHEWs, 1985; DE ROBERTIS \& DE ROBERTIS, 1993; CARVALHO, 1994).

As proteínas representam o principal componente das membranas e possuem importante papel, não só na estrutura mecânica da membrana, mas também como transportadoras ou canais de transporte. Além disso, podem estar relacionadas com propriedades reguladoras ou de reconhecimento (DE ROBERTIS \& DE ROBERTIS, 1993).

As teorias sobre a organização das membranas baseiam-se em informações indiretas. Dentre os mais diversos 
modelos de estrutura das membranas propostas, o do mosaico fluido de SINGER \& NICOLSON (1972), é dos mais aceitos. Este modelo postula que (1) os lipídios e as proteínas estão dispostos num arranjo tipo mosaico; (2) as membranas são estruturas quase fluidas, onde tanto os lipídios quanto as proteinas integrais são capazes de executar movimentos de translação em toda a camada dupla (DE ROBERTIS \& DE ROBERTIS, 1993).

Neste trabalho, as proteínas integrais das membranas intercalam-se em maior ou menor extensão numa camada lipídica dupla contínua (Figura 2). Este arranjo baseia-se no caráter anfipático destas proteínas, cujas regiões polares afloram na superfície da membrana, enquanto as não polares engastam-se no interior hidrofóbico da membrana.

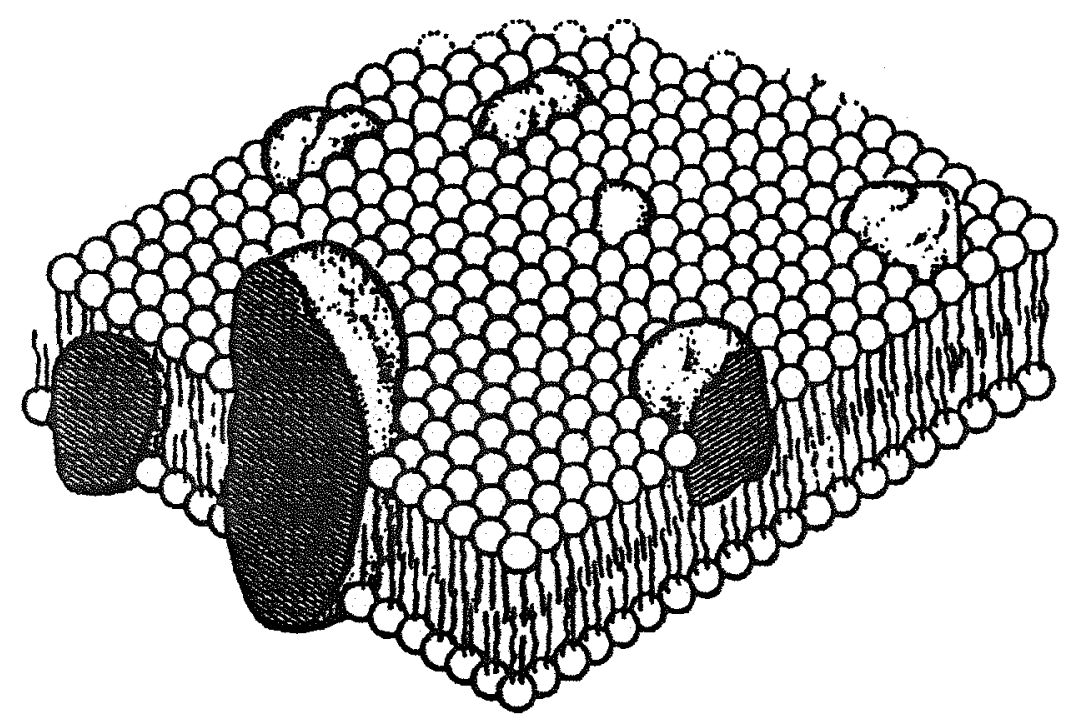

Figura 2 - Modelo de mosaico fluido proposto por SINGER \& NICOLSON (1972) . 
De acordo com esse modelo, a estrutura da membrana adquire permeabilidade seletiva. A permeabilidade das membranas é uma expressão da liberdade com que a água e os solutos podem passar através delas. Depende não somente da substância que está penetrando, mas também da membrana em si, pois não são todas iguais em todos os organismos. Há circunstâncias nas quais a permeabilidade a um soluto varia de uma fase para outra na vida de uma célula; assim, tanto a senescência como a imposição a um estresse, como a desidratação, aumentam a permeabilidade (SIMON, 1974).

Portanto, o processo de envelhecimento resultaria em uma desestruturação da membrana, com reflexos principais sobre sua capacidade de regular o fluxo de solutos, tanto de dentro para fora como no sentido oposto, considerando-se uma célula ou uma organela. Essas mudanças ocorreriam nos ácidos graxos insaturados pela ação dos radicais livres (WILSON Jr. \& MCDONALD Jr., 1986).

A rancificação do óleo, como causa do declínio da viabilidade das sementes, foi primeiro proposta por KALOYEREAS (1958). Ele verificou que o óleo de sementes de Pinus spp, sementes estas que tiveram baixo desempenho no teste de germinação, foram oxidadas pelo anion iodo, indicando que os lipídios da semente teriam reagido com o oxigênio. Também demonstrou em estudo de laboratório, que a peroxidação dos lipídios poderia ser a causa direta da deterioração de sementes armazenadas. 
Segundo HARTMAN \& ESTEVES (1982), podemos distinguir dois tipos de rancidez, a hidrolítica e a oxidativa. Na rancidez hidrolítica as moléculas de gordura são cindidas em glicerol (ou glicerídeos parciais) e ácidos livres. A presença de água é indispensável para se efetivar esta reação; ela pode ser decorrente de um processo bioquímico (hidrólise enzimática devido a microrganismos ou enzimas) ou, simplesmente, de reações químicas (hidrólise não-enzimática). A rancidez oxidativa ou peroxidação é um processo degradativo que ocorre quando oxigênio atmosférico ou dissolvido na amostra contacta com a região sensível da molécula de triglicerídeo. Tal região inclui uma dupla ligação e o respectivo carbono $\alpha$-metilênico. A oxidação é tanto mais intensa quanto maior for o grau de insaturação do ácido graxo componente do triglicerídeo.

Em presença de oxigênio, os ácidos graxos insaturados oxidados produzem radicais livres e os hidroperóxidos insaturados, que são os chamados produtos primários. Estes sofrem novas reações produzindo compostos de menor peso molecular, os produtos secundários. Essa reação é acelerada por uma classe de enzimas denominada lipoxigenases, que ocorrem em muitas espécies de sementes, especialmente em soja (WILSON Jr. \& McDONALD Jr., 1986). O processo que envolve enzima é dito enzimático e $\circ$ não enzimático é comumente chamado de "autoxidação". 
Um radical livre é um átomo, ou grupo de átomos, com um elétron não pareado e que tem a capacidade de doar ou remover um elétron de uma molécula vizinha. Ao serem formados em tecidos de metabolismo alterado, os radicais livres podem vazar para tecidos vizinhos, causando danos biológicos. Existe uma grande quantidade de radicais livres, mas os mais importantes são a hidroxila $\left(\mathrm{OH}^{-}\right)$e o superóxido $\left(\mathrm{O}_{2}^{-}\right)$(MATTHEWS, $1985 ;$ DE ROBERTIS \& DE ROBERTIS, 1993; CARVALHO, 1994).

Sob condições normais, as células têm mecanismos para superar a ação dos radicais livres: são as substâncias que recebem o nome de "scavengers" (extratores, removedores), as quais reagem com o radical livre, eliminando-o. Entre essas substancias, destacam-se os antioxidantes (dos quais um dos mais eficientes é o $\alpha$-tocoferol, ou seja, a vitamina E), que tem funcionado no sentido de prevenir o envelhecimento (WILSON Jr. \& MCDONALD Jr., 1986).

Contudo, a correlação entre a peroxidação dos lipídios e a deterioração de sementes nem sempre tem sido verificada; alguns trabalhos indicam que a deterioração leva a uma redução na quantidade de lipídios na semente (GORECKI \& HARMAN, 1987; BASAVARAJAPPA et a1., 1991); ao passo que outros não estabelecem essa relação (POWELL \& HARMAN, 1985). De uma forma geral, os autores parecem concordar que a primeira consequência da deterioração é a 
desestruturação dos sistemas de membranas, resultando em aumento da permeabilidade (fato amplamente utilizado na rotina de análise do vigor de sementes, como demonstra o teste de condutividade) sem, contudo, chegar-se a um consenso sobre quais seriam as causas básicas dessa desestruturação (CARVALHO, 1994).

Baseado em considerações teóricas, SIMON (1974) propôs que as membranas de sementes secas estão desorganizadas, adquirindo forma hexagonal, não havendo barreiras em volta do citoplasma de cada célula. Com a embebição (reidratação), as membranas se reorganizam, retornando à forma lamelar e readquirindo a permeabilidade seletiva. Erevisível que por um curto período no início da embebição, quando os constituintes das membranas de cada célula ainda estão em fase de reorganização, os solutos possam ser lixiviados para fora das células (WEBster \& LEOPOLD, 1977).

Sementes de soja são sensiveis a baixas temperaturas durante a germinação, injúrias ocorrem a $10^{\circ} \mathrm{C}$ ou menos. A maior sensibilidade ocorre durante as primeiras horas de embebição, onde baixas temperaturas causam alterações no processo de reorganização das membranas, já que os fosfolipídios não estão aptos para trocas rápidas na arquitetura hexagonal (desidratada) para a lamelar (reidratada) (BRAMLAGE et a1., 1978). 
Outro fenômeno que altera as membranas de sementes, é o chamado dano por embebição. Quando sementes secas são embebidas rapidamente, injúrias ocorrem, principalmente quando o conteúdo de água dessas sementes é inferior a $13 \%$ (HOBBS \& OBENDORF, 1972). Outros trabalhos indicam que os primeiros cinco minutos de embebição são críticos para a entrada de água, podendo ocorrer danos ou injúrias às membranas caso esta embebição seja muito rápida (PARRISH \& LEOPOLD, 1977).

O mecanismo de dano por embebição e/ou à baixa temperatura tem sido considerado como injúria física às membranas, como um bloqueio ao sistema metabólico e, ainda, como uma combinação de injúria metabólica e física, possivelmente a nível molecular (POLLOCK, 1969). A rápida embebição em sementes com baixo grau de umidade pode causar uma hidratação diferencial nas proteínas componentes dos tecidos, resultando em pressões e até quebras nos cotilédones. A combinação de temperaturas baixas e rápida hidrataça das proteínas, pode resultar em aumento na exsudação e, possivelmente, ruptura das estruturas das membranas envolvendo funções metabólicas (OBENDORF \& HOBBS, $1970)$

Com o avanço da deterioração, algumas manifestações bioquímicas ocorrem, como a respiração que, sob condições aeróbicas, oxidam os açúcares e gorduras de células vegetais, produzindo gás carbônico, água e liberando energia 
sob a forma de calor. O fenômeno é quimicamente complexo, envolvendo a participação de enzimas; durante a respiração, para cada volume de oxigênio, a semente desprende um certo volume de gás carbônico; a relação entre os dois volumes é denominado quociente respiratorio ( $\left.R Q=\mathrm{CO}_{2} / \mathrm{O}_{2}\right)$. O RQ é maior em sementes deterioradas (TOLEDO \& MARCOS FILHO, 1977), já que a captação de oxigênio é menor (WOODSTOCK, 1973).

Associados a este declínio na atividade respiratória durante o processo de deterioração (PARRISH \& LEOPOLD, 1978; WILSON Jr. \& MCDONALD Jr., 1986), outros eventos tem sido mencionados; diminuição na síntese e atividade enzimática (WOODSTOCK, 1973), menor produção de ATP (ANDERSON, 1977; WANG \& ZHAO, 1990), acúmulo de acetaldeído e etanol a níveis possivelmente tóxicos (WOODSTOCK \& TAYLORSON, 1981), desnaturação das proteínas (WILSON Jr \& \& McDONALD Jr., 1986), menor número e eficiência de atuação das mitocôndrias (CHING, 1973), acúmulo de mutações deletéreas (VILLIERS \& EDGCUMBE, 1975) incluindo degradação do DNA e ribossomos (VAN ONCKELEN et a1., 1974) e alterações nas reservas armazenadas (TOLEDO \& MARCOS FILHO, 1977) resultando em menores quantidades de carboidratos totais (CHAMMA et al., 1990) e solúveis (EDJE \& BURRIS, 1970) e maiores quantidades de açúcares redutores (SHARMA et al., 1989).

Com a degeneração das membranas celulares e a redução das atividades biossintéticas (alterações bioquímicas), manifestações agora fisiológicas ocorrem e 
acabam levando a semente à morte. Germinação e crescimento inicial mais lentos, redução do potencial de armazenamento e da taxa de crescimento, menor uniformidade, maior sensibilidade a adversidades, redução da emergência das plântulas em campo, formação de plantas estéreis (pólen), aberrações morfológicas (plântulas anormais), maior especificidade do ambiente para germinação e perda do poder germinativo, são as manifestações mais comuns (DELOUCHE, 1969)

Os testes de vigor, embora não totalmente padronizados, vêm sendo considerados importantes e eficazes para avaliar o estágio de deterioração das sementes. Estes testes são capazes de revelar pequenas diferenças de deterioração de lotes de sementes, enquanto o de germinação acusa apenas grandes diferenças (TOLEDO \& MARCOS FILHO, 1977). A deterioração de sementes, reune diversos eventos, cada um influenciado por diferentes condições ambientais que, com a continuidade do processo, resultam primeiro em perda do vigor e por último, na perda da viabilidade (DELOUCHE \& BASKIN, 1973).

O grau de umidade da semente e a temperatura de armazenamento são os dois fatores de maior influencia sobre a manutenção da viabilidade das sementes (WARD \& POWELL, 1983). A maioria das espécies cultivadas possui características ortodoxas, na qual um aumento do conteúdo de agua das sementes ou da umidade relativa do ambiente, ou ainda, na temperatura de armazenamento, resulta em uma rápida 
perda da viabilidade (ROBERTS, 1973), reduzindo a porcentagem e/ou velocidade de emergência em campo, além do menor potencial de armazenamento (MATTHEWS, 1981). HARRINGTON (1972) sugeriu que, em condições normais de temperatura e umidade durante o armazenamento de sementes, para cada $1 \%$ de redução na umidade da semente ou a cada $5^{\circ} \mathrm{C}$ de redução na temperatura do ambiente, a longevidade da semente é duplicada. Admitindo-se, ainda, que os efeitos sejam aditivos, uma semente de alto vigor poderia ser deteriorada 500 vezes mais rápido a $40^{\circ} \mathrm{C}$ e $18 \%$ de teor de água do que a $20^{\circ} \mathrm{C}$ e $8 \%$ de água.

Extrapolando estes resultados para experimentos no qual o conteúdo de água das sementes é variável durante o armazenamento, é de se esperar que sementes armazenadas embebidas por um longo período tenham um menor tempo de vida. Todavia, é comum na natureza, a observação de sementes que sobrevivem enterradas no solo por muitos anos e ainda permanecem viáveis (VILLIERS \& EDGCUMBE, 1975). Na verdade, a capacidade que algumas sementes possuem em permanecer vivas mesmo quando secas, é uma necessidade biológica devido ao mecanismo de dispersão, já que em ambiente natural, a maioria das sementes perde água por um curto período apenas. Depois da dispersão, as sementes caem na superfície do solo, onde são reidratadas (VILLIERS \& EDGCUMBE, 1975). Sementes embebidas, estão aptas em reparar danos celulares que induzem o envelhecimento, isso ocorre normalmente nas primeiras horas de embebição (MATTHEWS, $1985)$ 
Danos em sementes secas podem ser devido à peroxidação de lipídios e proteínas das membranas. Esse processo é autocatalítico e, em geral, danifica todas células. O fato dos tecidos estarem secos não previne necessariamente a reação de peroxidação. Agua ao redor das macromoléculas faz com que estas permaneçam em estado semicristalino; em células secas a pequena quantidade de água remanescente restringe a tenacidade das células coloidais e ainda permite a peroxidação, devido à proximidade da água e do oxigênio com a dupla ligação de lipídios insaturados da membrana citoplasmática. Embora muitas enzimas controlem estas reações, especialmente as que envolvem estruturas unitárias, estas provavelmente não ocorrem nestas condições (VILLIERS \& EDGCUMBE, 1975).

Assim, a perda da viabilidade de sementes armazenadas secas é causada pela sua inabilidade em operar o sistema de reparo dos tecidos devido ao baixo teor de água disponíve1. Consequentemente, os danos se acumulam e somente poderão ser reparados quando as sementes forem embebidas para a germinação (VILLIERS \& EDGCUMBE, 1975). Em sementes enterradas no solo, a sequência de ganho e perda de água, que ocorre naturalmente, faz com que esse processo todo seja desencadeado e com isso a semente é capaz de permanecer viável por um longo período. 
20.

\subsection{Fases da Germinação}

Apesar da dificuldade em se definir o fenômeno da germinação, é usual admitir-se que o processo compreende uma sequência ordenada de atividades metabólicas que resultam na retomada de desenvolvimento do embrião, produzindo uma plântula normal (MARCOS FILHO, 1986).

Diversos autores propuseram diferentes sequências para o processo de germinação, variando em grau de detalhamento e tipo de abordagem. POPINIGIS (1977) considerou as seguintes etapas:
a) Embebição;
b) Aumento da respiração;
c) Formação de enzimas;
d) Digestão enzimática das reservas;
e) Mobilização e transporte de reservas;
f) Assimilação metabólica;
g) Crescimento e diferenciação dos tecidos.

o primeiro fenômeno que se verifica na germinação é a absorção de água, que provoca na semente, entre outras coisas, um decréscimo na resistência mecânica do tegumento. A entrada de água é um processo físico relacionado com as propriedades dos colóides e sua extensão depende da composição química da semente, da permeabilidade do tegumento e da disponibilidade de água no ambiente. A 
velocidade de embebição depende, além desses fatores, da área de contato semente/água, da temperatura, da pressão hidrostática e da condição fisiológica da semente (POPINIGIS, 1977 ; LABOURIAU, 1983; YOUNG et a1., 1983; CARVALHO \& NAKAGAWA, 1988).

A embebição é um tipo especial de difusão, provocado pela atração entre moléculas de água e o material que constitui a superfície absorvedora (MARCOS FILHO, 1986). o movimento da água para o interior da semente é determinado pelas diferenças de potencial de água da semente e do substrato. Geralmente, o potencial em sementes secas é menor que o de solos úmidos (ou substratos úmidos), o que faz com que a água, movimentando-se em direção ao menor potencial, penetre na semente (YOUNG et al., 1983). A absorção prossegue até o momento em que os potenciais atinjam os mesmos valores, caracterizando o estado de equilibrio.

Segundo BEWLEY \& BLACK (1983), o padrão inicial de embebição para a maioria das sementes, inclusive a soja, é trifásico; conforme mostra a Figura 3 .

A fase I é caracterizada por uma rápida absorção de água nos primeiros minutos, e chega a ser descrita como descontrolada (PARRISH \& LEOPOLD, 1978). E consequência das forças mátricas ( $\mathbf{m})$ das paredes da célula e dos constituintes da semente e, como independe da atividade metabólica da semente, pode ocorrer sob condições anaeróbicas, sob baixas temperaturas (em forma mais lenta), 
em sementes viáveis, dormentes, em tecidos vivos ou não (MARCOS FILHO, 1986). Sementes onde predominam as reservas cotiledonares atingem $35-40 \%$ de água cerca de 1 a 2 horas após o início do processo, enquanto as endospermáticas, nesse mesmo período, alcançam 25-30\% (CARVALHo \& NAKAGAWA, 1988). Em sementes de soja, a fase I se estende por cerca de $6 \mathrm{~h}$ e atinge $550 \mathrm{~g} \mathrm{H}_{2} \mathrm{O} / \mathrm{kg}$ peso fresco (ARMSTRONG \& MCDONALD, 1992).

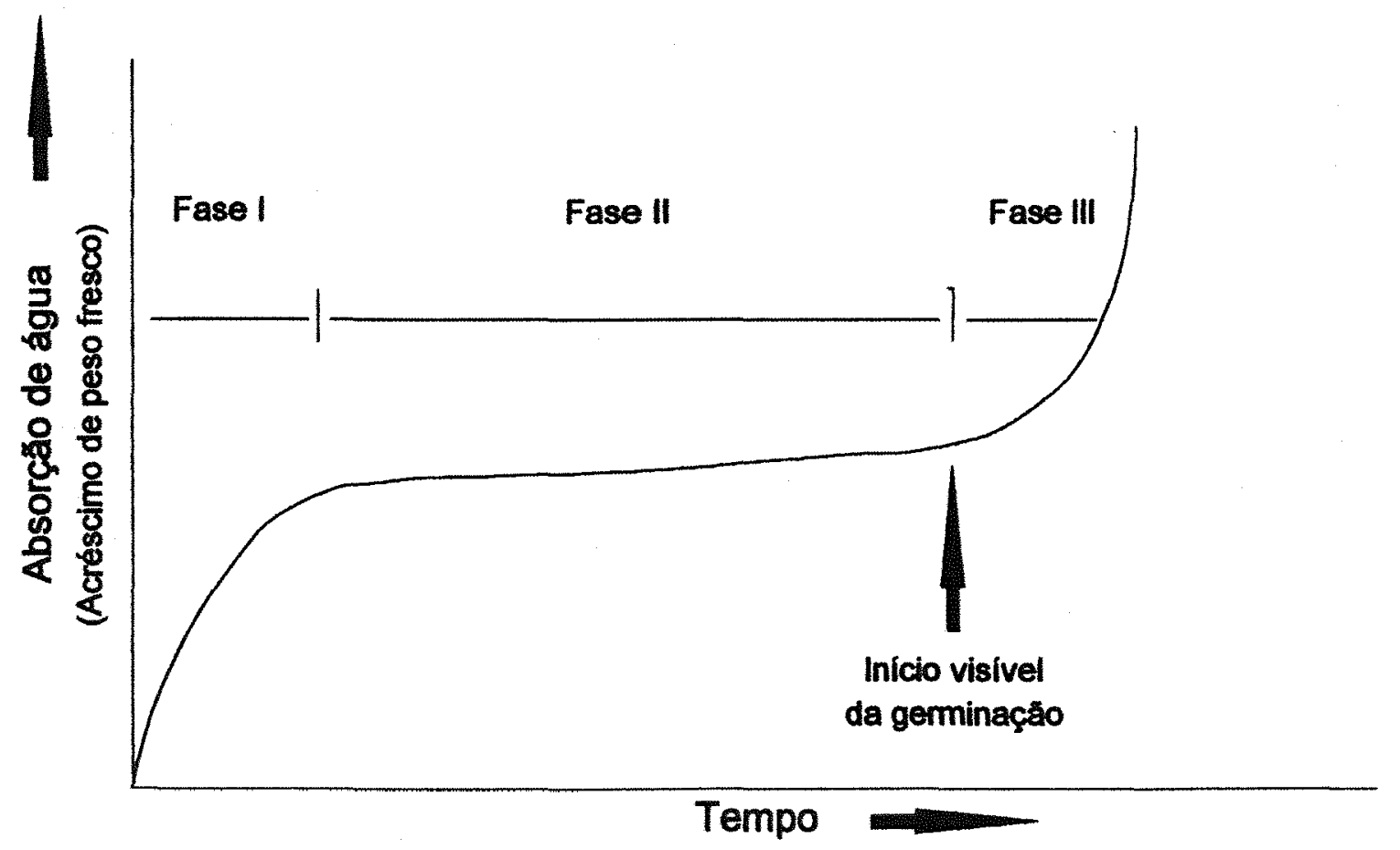

Figura 3 - Padrão trifásico de absorção de água por sementes em germinação (In: BEWLEY \& BLACK, 1983). 
À medida em que se inicia a embebição, as sementes liberam açúcares, ácidos orgânicos, íons, aminoácidos e proteínas, em quantidades inversamente proporcionais ao estado de organização dos sistemas de membranas, ou seja, as mais deterioradas, com tegumentos trincados ou escarificados, normalmente liberam maiores quantidades de exsudatos. Nas sementes mais vigorosas, o restabelecimento da integridade do sistema de membranas celulares ocorre minutos após o início da hidratação, minimizando o problema (MARCos FilHo, 1986). Além disso, em condições de campo, esses solutos (principalmente os açúcares) podem estimular o desenvolvimento de fungos e bactérias, prejudicando o estabelecimento das plântulas.

A intensificação do processo respiratório resulta na produção de grandes quantidades de energia, a qual vai ser utilizada na degradação das substâncias de reserva. Estas por serem de grande tamanho precisam ser desdobradas, para que possam ser transportadas para o tecido meristemático. Assim, terá início a fase II, que pode ter uma duração de 8 a 10 vezes superior à da fase I, algumas espécies podem não apresentar esta fase. Esta é uma fase Iinear, em que há pouca ou nenhuma absorção de água pela semente; o potencial mátrico já é menos negativo, equivalendo ao potencial osmótico. As sementes mortas e dormentes se mantém neste nível de hidratação, e não avançam para a fase seguinte. A desidratação, antes do processo de emissão da 
raiz primária ou outras estruturas (etapa II), é tolerada sem que se apresentem danos irreparáveis ao embrião; o processo de germinação é retomado quando as condições hídricas forem favoráveis (HEGARTY, 1977a).

Em seguida, observa-se o crescimento visível do eixo embrionário, caracterizando o início da fase II da germinação e a retomada da absorção de quantidades crescentes de água. Bioquimicamente, nessa fase ocorre a reorganização das substâncias desdobradas na fase I e transportadas na II em substâncias complexas, para formar o citoplasma, o protoplasma e as paredes celulares, permitindo o crescimento do eixo embrionário e posterior estabelecimento da plântula (BEWLEY \& BLACK, 1983 e 1985). O teor de água encontrado para o início da etapa II de sementes de soja está na faixa de 50-55\% para BURCH \& DELOUCHE (1959) e PESKE \& DELOUCHE (1985); e segundo ARMSTRONG \& MCDONALD (1992), a protrusão da raiz ocorre após 21 h de embebição, quando a semente atinge $650 \mathrm{~g} \mathrm{H}_{2} \mathrm{O} / \mathrm{kg}$ peso fresco.

\subsection{Reversibilidade da Deterioração}

As sementes são geralmente tolerantes a desidratação na maturidade e durante os primeiros estágios da germinação, mas uma vez que a germinação atinge seu estágio crítico (Fase III da embebição), elas tornam-se suscetíveis 
às injúrias por desidratação (SENARATNA et al., 1985). Segundo os mesmos autores, sementes de soja com $10 \%$ de água após 6 horas de embebição são capazes de tolerar a desidratação, mas após 36 horas um tratamento similar de desidratação induz a uma perda total da viabilidade.

A deterioração em sementes envolve modificações nas membranas celulares que podem predispor tecidos embrionários a danos durante a embebição (WOODSTOCK \& TAO, 1981); assim, o controle da hidratação das sementes pode proporcionar uma reversão na sua qualidade fisiológica através do processo de reparo de membranas (KNYPL \& KHAN, 1981; WOODSTOCK \& TAO, 1981; FU et al., 1988; PANDEY, 1988) ou possivelmente, por uma reorganização metabólica a nível celular (VILLIERS, 1974; VILLIERS \& EDGCUMBE, 1975; TILDEN \& WEST, 1985; PANDEY, 1988). Admite-se ainda, um efeito de contenção dos radicais livres e das reações de peroxidação dos lipídios (CHOUDHURI \& BASU, 1988).

o reparo durante a germinação é um evento hipotético, aceito por alguns pesquisadores e questionado por outros (TILDEN \& WEST, 1985). O reparo inclui uma reorganização espontânea dos fosfolipídios da membrana plasmática, o que de acordo com SIMON (1974), ocorre durante a hidratação das sementes. SIMON \& RAJA HARUN (1972) sugeriram que em sementes secas, as membranas celulares perdem sua integridade e que, durante a reidratação, há um pequeno período antes que a integridade seja restabelecida, 
durante o qual os solutos são lixiviados das células em grande quantidade. WOODSTOCK \& TAO (1981) relataram que a saída de eletrólitos de eixos embrionários de sementes de soja de baixo vigor, foi aproximadamente seis vezes maior do que o de eixos de alto vigor, e em ambos, a maior taxa de perda de eletrólitos foi mais pronunciada nos estágios iniciais de embebição, diminuindo com o tempo, não havendo inclusive mais exsudação depois de 20 horas. WEBSTER \& LEOPOLD (1977) afirmaram que após 20 minutos de embebição a $25^{\circ} \mathrm{C}$, os cotilédones de semente de soja anteriormente secos, já possuem as membranas reorganizadas, restabelecendo sua permeabilidade seletiva e evitando a exsudação excessiva. Os mesmos autores indicaram que, durante a embebição outros eventos ocorrem como, a reestruturação do retículo endoplasmático e o rápido desenvolvimento de numerosas cristas e denso estroma, o que se relaciona com o aumento da respiração. Outros trabalhos relataram aumentos nos processos de replicação do DNA após a embebição (BINO et al., 1992), e na síntese de RNA, proteínas e enzimas (KNYPL \& KHAN, 1981). Estes aumentos obtidos com os tratamentos de hidratação/secagem, podem ocorrer devido a remoção de certos inibidores, como o ácido abscísico (KHAN et al., 1978), sendo estas modificações mais marcantes no eixo embrionário do que nos cotilédones (FU et al., 1988).

Várias hipóteses são propostas para explicar a lixiviação dos solutos durante a fase de embebição das 
sementes, sendo três as principais. A primeira hipótese propõe que os solutos lixiviados durante a embebição estariam localizados em depósitos na superfície ou no apoplasto das sementes (SIMON, 1974), fato este divergente do obtido por SIMON \& RAJA-HARUN (1972) que verificaram que o processo se repetia tantas vezes quantas se repetisse onsaio; por outro lado, embriões de ervilha previamente umedecidos, ou ainda que não tinham sido submetidos à secagem durante a sua maturação, não perdiam eletrólitos quando imersos em água. SIMON \& MILLS (1983), mostraram que a quantidade elevada de eletrólitos e de potássio perdidos em 24 horas, é bem superior a que parece existir extra célula; além disso a grande diversidade dos solutos perdidos sugere a origem citoplasmática, o que inviabiliza esta primeira hipótese.

$$
\text { LARSON (1968) e PERRY \& HARRISON (1970) }
$$

apresentaram a segunda hipótese, a da ruptura das membranas. Eles admitiram que devido ao elevado gradiente de potencial de água no início da embebição as membranas das células poderiam se romper, o que dispersaria seus componentes. Porém SIMON (1984) demonstrou que a lixiviação ocorre ainda que a embebição seja lenta em embriões de ervilha, e que a lixiviação de potássio continua por horas após as células periféricas terem sido umedecidas.

A terceira e mais aceita das hipóteses foi proposta por SIMON \& MILLS (1983) e SIMON (1984). Nesta, admite-se que sementes secas possuem membranas 
desorganizadas, sem barreiras em volta do citoplasma de cada célula, o que facilita a lixiviação de solutos; com a embebição sua condição de semipermeabilidade é restabelecida. Trabalhos sugerem que sementes com teor de água abaixo de $20 \%$, apresentam membranas porosas, não mais a prova d'água podendo ser permeáveis a solutos (LUZZATI \& HUSSON, 1962; SENARATNA et al., 1985). Após a hidratação, as membranas retornam à forma lamelar evitando a perda de eletrólitos. Esta hipótese foi contestada por McKERSIE \& SENARATNA (1983) mediante a comparação da velocidade de perda dos solutos durante a embebição com modelo matemático da hidratação num corpo esférico. É colocada em dúvida a existência da fase hexagonal em sementes, e admite-se que a mudança da permeabilidade seja devido ao rompimento ou a inativação da bomba de íons.

ROBERTS (1981) admitiu que alguns dos danos são reversíveis com a reidratação, provavelmente devido à operação de reparo subcelular, porém danos severos desenvolvidos na penúltima fase antes da morte, são irreversíveis e levam à redução do vigor e a produção de plântulas anormais, já que a maioria dos sistemas subcelulares estariam danificados, incluindo o genótipo. PANDEY (1988) também sugeriu a existência de um estado crítico de deterioração, a partir do qual a viabilidade não pode ser restaurada. 
PERL \& FEDER (1981), trabalhando com sementes de pimenta submetidas ao tratamento de "envigoramento", através do aumento do conteúdo de água da semente, obtiveram benefícios independentemente do cultivar utilizado. Já SALIM \& TODD (1968), observaram que, em sementes de cevada e trigo, a resposta a esse tipo de tratamento, depende do cultivar empregado. Diferenças quanto ao vigor dos lotes, também podem determinar respostas distintas em sementes submetidas a hidratação. Evidências mostraram que o envigoramento ou reparo somente podem ser notados em sementes deterioradas ou com baixo vigor (SAVINO et al., 1979; WARD \& POWELL, 1983; BURGASS \& POWELL, 1984). Resultados contraditórios foram apresentados por HEGARTY (1970) e BERRIE \& DRENNAN (1971).

\subsection{Condicionamento Fisiológico}

o conceito de tratamento de sementes é amplo e inclui a aplicação ou estímulo de natureza química, biológica ou física às sementes, com a finalidade de protegêlas ou de modificar seu comportamento e/ou das plântulas e plantas resultantes.

Um dos procedimentos mais promissores é o tratamento pré-semeadura, envolvendo a iniciação do metabolismo de germinação, atraves do controle da absorção de água pela semente sem, no entanto, permitir a protrusão da 
raiz primária. A hidratação das sementes pode ser efetuada mediante exposição à atmosfera úmida, embebição em substrato úmido e imersão em soluções osmóticas; esse tratamento pode ser contínuo até que as sementes atinjam o grau de umidade programado, ou envolver ciclo(s) hidratação/secagem. O processo tem sido citado através de denominações como "endurecimento", "hardening" e "advancing" (HEYDECKER et al., 1973; COLE \& WHEELER, 1974; BUSSEL \& GRAY, 1976; A-AS-SAQUI \& CORLETO, 1978; BRADFORD, 1986); condicionamento osmótico ou osmocondicionamento (HEYDECKER et al., 1973; KHAN et al., 1976; KNYPL \& KHAN, 1981); "priming" (HEYDECKER et al., 1975; HERNER, 1986); "envigoramento" (HEYDECKER et al., 1975; PERL, 1979 ) e condicionamento fisiológico (MARCOS FILHO, 1986; DONI FILHO, 1992), termo que passaremos a adotar neste trabalho, já que o objetivo básico do tratamento é a alteração da manifestação fisiológica da semente.

A técnica de condicionamento fisiológico desenvolvida por HEYDECKER et al. (1973, 1975), apesar de fisiologicamente complexa é simples em conceito, sendo as sementes submetidas a um período de pré-embebição, para que depois sua raiz primária possa emergir mais rapidamente que o normal. De acordo com o padrão trifásico de embebição (BEWLEY \& BLACK, 1985), a semente passaria por todas as fases preparatórias essenciais à germinação (etapas I e II), sem atingir a fase de alongamento celular e emergencia da raiz primária (etapa III) (HEYDECKER et al., 1975). 
HEGARTY (1977b) discutiu o efeito do teor de água em sementes ortodoxas durante o armazenamento e propóe uma representação esquemática das fases de deterioração, ativação e reparo, e germinação de sementes em diferentes níveis de água (Figura 4 ).

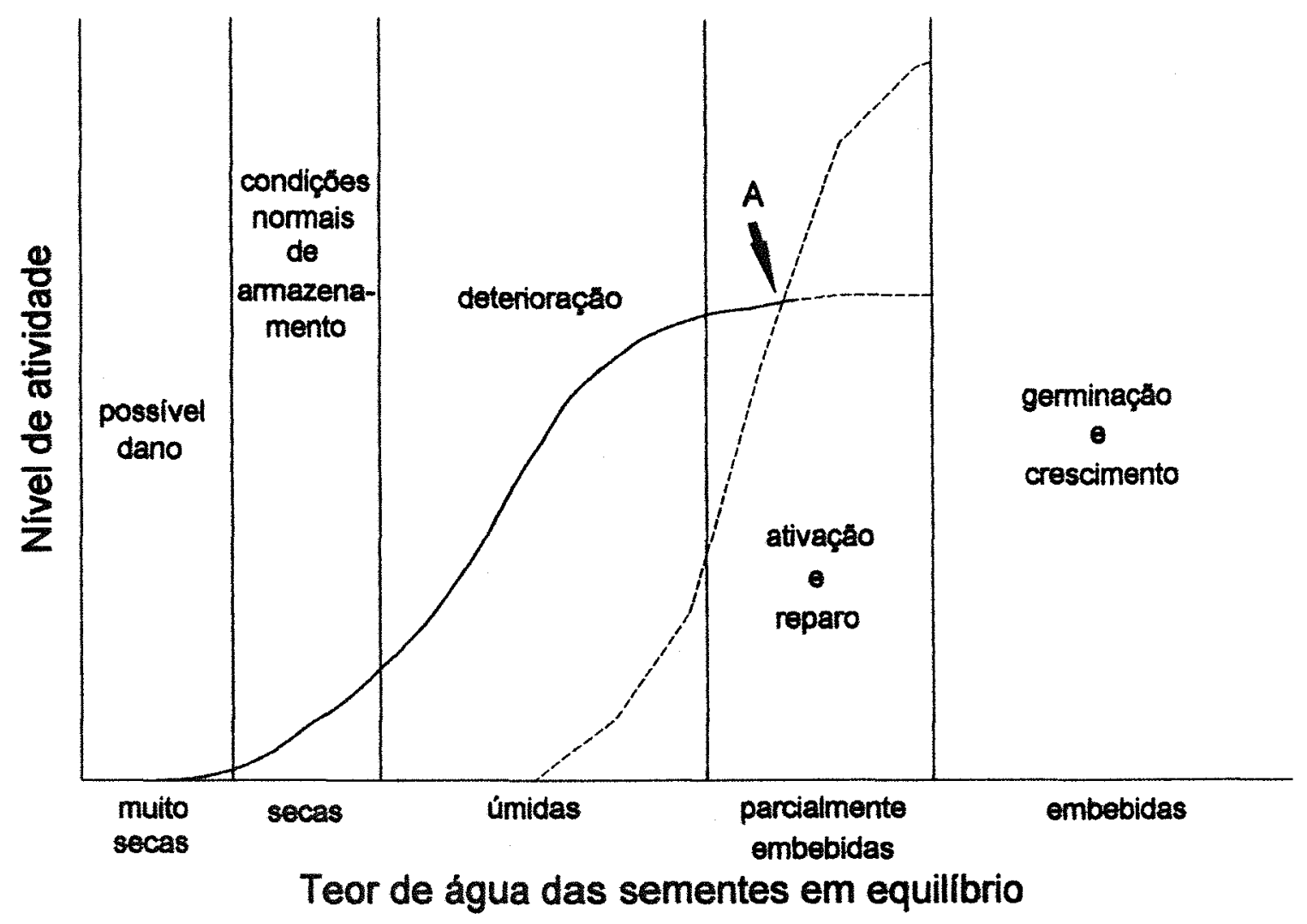

Figura 4 - Representação esquemática das fases de deterioração, ativação e reparo, e germinação de sementes em diferentes níveis de água (In: HEGARTY, $1977 \mathrm{~b})$. 
Em teores muito baixos de água, as sementes estão sujeitas a peroxidação dos lipídios (WILSON Jr. \& MCDONALD Jr., 1986), ficando a viabilidade prejudicada, mas em geral, com o aumento do nível de água a deterioração é acelerada. Se suficientemente úmidas, as sementes germinam e, num nível intermediário, tem início o processo de ativação e reparo celular que com o tempo supera a própria deterioração no ponto A (representado na Figura 4 ).

De modo geral, a técnica de condicionamento fisiológico faz com que a velocidade de germinação seja maior em sementes de trigo tratadas, fato este acompanhado por um aumento na síntese de proteínas do embrião. Todavia, a resposta ao tratamento depende do grau de deterioração da semente (DELL'AQUILA \& TRITTO, 1990). KHAN et a . (1980/81) obtiveram resultados indicativos que aumentos na síntese de proteínas em sementes osmocondicionadas de alface, estão relacionados com a velocidade de germinação. PERL (1979) trabalhando com diversos tempos de embebição em sementes de algodão sob condições usuais de germinação, determinou diversas modificações bioquímicas (Figura 5). 


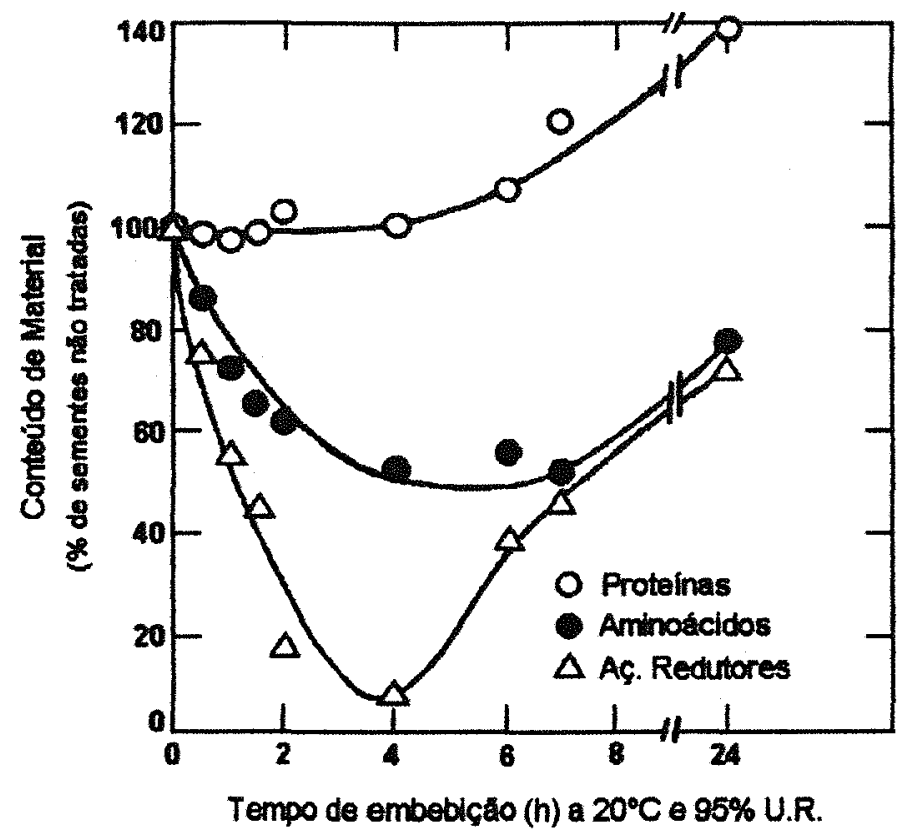

Figura 5 - Modificações bioquímicas em sementes de algodão durante a fase de embebição do processo de germinação (In: PERL, 1979).

A Figura 5 , mostra que há uma diminuição significativa nos níveis de aminoácidos e açúcares redutores durante as 4 horas iniciais da embebição, havendo posteriormente um aumento. As proteínas também aumentaram após 4 horas, chegando a níveis expressivos após 24 horas de embebição. Segundo o mesmo autor, a fração lipídica permaneceu constante durante 8 horas, quando então, diminuiu cerca de $60 \%$ após 24 horas de embebição.

FU et al. (1988) utilizaram sementes de amendoim osmocondicionadas com $20 \%$ de polietileno glicol (PEG) por 48 horas a $15^{\circ} \mathrm{C}$, e obtiveram acréscimos na produção 
de ATP, na atividade de várias enzimas, na síntese de ácido nucleico e etileno e até indícios de reparo no DNA; isso durante a fase de embebição do processo de germinação quando comparado à testemunha.

Existem resultados contraditórios na literatura, quanto ao metabolismo do DNA em sementes condicionadas. DELL'AQUILA \& TRITTO (1990), descreveram aumentos na síntese de DNA do embrião de sementes de trigo, enquanto KHAN et al. (1980/81) concluiram que não houve acréscimos em sementes de alface condicionadas. Os últimos autores também relacionaram acréscimos na síntese de RNA, ativação de numerosas enzimas e hormônios, com especial inativação do ácido abscísico (ABA).

\subsubsection{Metodologia do Condicionamento}

o condicionamento fisiológico envolve a hidratação controlada da semente; a água pode ser aplicada por diversos métodos:

- embebição simples: feita através do equilíbrio com vapor de água da atmosfera ou através de embebição em substrato úmido, ou ainda, sob imersão em água.

- ciclos de hidratação/secagem("hardening"): utiliza um ou mais ciclos de embebição seguidos de secagem.

- embebição em soluções com concentração osmótica definida ("priming" ou condicionamento osmótico ou 
osmocondicionamento): envolve o uso de produtos quimicamente inertes, como polietileno glicol (PEG), manitol e sais inorgânicos.

A tendência natural de difusão da água é fluir de um estado de maior energia para um de menor energia (BEWLEY \& BLACK, 1985). Utiliza-se o potencial hídrico (Th) para medir a capacidade das moléculas de água executarem trabalho ou movimento, podendo ser expresso em unidades de energia (joule e erg) e essas unidades podem ser convertidas em unidades de pressão: erg $x \mathrm{~cm}^{-3}=10^{-4}$ joule $x\left(\mathrm{~kg} \mathrm{H}_{2} \mathrm{O}\right)^{-1}=$ $10^{-6}$ bar $=0,987 \times 10^{-6}$ atm (LABOURIAU, 1983) e $0,1 \mathrm{MPa}=1$ bar $=0,987$ atm (SUTCLIFFE, 1980).

o potencial hídrico de uma solução é designado de osmótico (Yo) e se refere ao nível de energia da água nesta solução. Neste caso, o potencial osmótico é inversamente proporcional à concentração de solutos na solução ou seja, quanto maior a concentração de solutos, menor o potencial resultante (SHIOGA, 1990). A técnica de condicionamento osmótico ou "priming" envolve o uso de solutos, portanto, o potencial hídrico da solução estará relacionado diretamente ao potencial osmótico em si.

o potencial hídrico denominado mátrico ( $\mathbf{m})$, resulta da interação entre a água e uma matriz (argilas, proteínas ou polissacarídeos de paredes celulares). Estas superfícies, geralmente, têm uma carga negativa que atrai o lado positivo da molécula de água, este é o chamado processo 
de hidratação e é responsável pela primeira fase de absorção de água pelas sementes na germinação (SALISBURY \& ROSS, 1985). Segundo os mesmos autores, papel de filtro, madeira, solo e gelatina, geralmente tem um potencial mátrico extremamente negativo (ao redor de $-300 \mathrm{MPa}$ ), enquanto 0 mesmo material saturado de água pura, tem um potencial mátrico igual a zero. Na embebição em substrato úmido, a quantidade de água que entra na semente é determinada pela diferença de potenciais, sendo o mátrico o principal.

o potencial de pressão ou hidrostático ( $p$ ), normalmente positivo, origina-se de uma força resultante da pressão exercida pela solução celular sobre a parede da célula em função da absorção e da retenção de água, sob a influência do potencial osmótico, que gera, por parte da parede celular, uma pressão igual mas de direção oposta (BEWLEY \& BLACK, 1985).

As relações hídricas entre a semente e o ambiente (substrato artificial ou solo) passaram a ser explicadas em função do valor do potencial hídrico (Th), definido quantitativamente pela seguinte expressão (LABOURIAU, 1983):

$$
\begin{aligned}
& \Psi_{h}=+\Psi_{m}+\Psi_{p} \\
& \Psi_{h}=\text { Potencial hídrico } \\
& \Psi_{o}=\text { Potencial osmótico } \\
& \Psi_{m}=\text { Potencial mátrico } \\
& \Psi_{p}=\text { Potencial de pressão }
\end{aligned}
$$


A entrada de água nas sementes é um processo altamente dependente de fundamentos físico-químicos, governados pelas propriedades da água, assim sendo, a embebição está relacionada com as propriedades dos colóides, sofre influências das condições ambiente e da composição do solvente que afetam a velocidade do processo (LABOURIAU, 1983). A quantidade máxima de agua absorvida nesta etapa não se altera, mesmo em sementes com diferenças de vigor; porém, segundo MATTHEWS \& POWELL (1986), lotes de sementes com baixo vigor apresentam uma embebição mais rápida do que os lotes de sementes com alto vigor, também a integridade do tegumento interfere na taxa de absorção de água, conforme verificaram OLIVEIRA et al. (1984) em sementes de soja.

Para o condicionamento, a quantidade de água a ser fornecida à semente não deve permitir que ela passe da fase II da embebição proposta por BEWLEY \& BLACK (1983). Isto pode ser alcançado limitando-se o tempo de embebição ou a quantidade de água disponível para a semente, influenciada pela temperatura em que é realizado (HEYDECKER \& COOLBEAR, $1977)$

A embebição feita através do equilíbrio com o vapor de água da atmosfera é muito demorada e, segundo HEYDECKER \& COOLBEAR (1977), pode apresentar outros problemas: 1) condensação de água sobre as sementes, ocasionando germinação indesejável; 2) proliferação de microrganismos; 3 ) aceleração nos processos de envel hecimento 
devido aumento de umidade e 4) dificuldade na manutenção da umidade relativa do ar e da temperatura de embebição.

Na metodologia utilizada por TILDEN \& WEST (1985), a embebição foi feita em substrato úmido; a água foi retida no substrato pelo potencial mátrico e os autores ressaltaram a vantagem de não haver possibilidade de se confundir os efeitos dos tratamentos com os efeitos devido à absorção ou dessorção de produtos químicos.

No método de imersão em água, o controle da embebição das sementes é feito limitando-se o tempo. Neste método não há interferência de produtos químicos, porém há o risco de danos causados pela embebição muito rápida (POWELL \& MATTHEWS, 1978 ; WOODSTOCK \& TAO, 1981).

Quando são analisados os ciclos de hidratação/secagem (BUSSEL \& GRAY, 1976; HEGARTY, 1977b; SAHA \& BASU, 1982; BHARATI et al., 1983; SAHA et al., 1990), percebe-se que, para algumas espécies, somente um ciclo de hidratação/secagem é suficiente; entretanto, para outras, são necessários 2 a 3 ciclos sucessivos para que os efeitos sejam conseguidos (BEWLEY \& BLACK, 1985; MUKHERJEE \& DEY (PATHAK), 1985 ; NATH et a 1., 1991).

A embebição pode ser feita de modo mais gradual e para isso basta controlar a quantidade de água disponível à semente, limitando-se o potencial mátrico ou o potencial osmótico. O potencial mátrico tem sido limitado através da disponibilidade de água do substrato empregado 
(geralmente papel-toalha, vermiculita ou solo). Quando o papel-toalha é usado, fixa-se o volume de agua e a quantidade de sementes e varia-se o número de folhas de papel. PERL \& FEDER (1981), TILDEN \& WEST (1985) e PANDEY (1988 e 1989) utilizaram de 1 a 5 folhas de papel com diâmetro de $150 \mathrm{~mm}$ umedecidos com $20 \mathrm{ml}$ de água. Já HEYDECKER et a 1. (1973) e FU et al. (1988) umedeceram folhas de papel-toalha com soluções de polietileno glicol de vários potenciais osmót icos.

o potencial osmótico pode ser controlado através de produtos químicos, tais como o polietileno glicol (PEG), manitol e sais inorgânicos $\left(\mathrm{NaCl}, \mathrm{MgSO}_{4}\right.$ e $\left.\mathrm{KNO}_{3}\right)$. Os sais inorgânicos apresentam o inconveniente de penetrarem nas sementes alterando o seu potencial hídrico, além de promoverem efeitos tóxicos (PRISCO \& O'LEARY, 1970), enquanto o manitol prejudicaria o alongamento de pêlos radiculares (JACKSON, 1965). O polietileno glicol (PEG) tem sido amplamente utilizado, é um polímero de alto peso molecular, não iônico, inerte (STEUTER et al., 1981), que não penetra pela parede celular (KNYPL \& KHAN, 1981) e não apresenta sinais de toxicidade (PARMAR \& MOORE, 1968; HEYDECKER \& COOLBEAR, 1977 ; BEWLEY \& BLACK, 1985).

Há uma ampla faixa de disponibilidade nos pesos moleculares de polietileno glicol (PEG), de 200 até 20.000 , para evitar a possibilidade das sementes absorverem - soluto, são empregados os de maiores pesos moleculares 
(SHARMA, 1973). Contudo, em função da densidade e da viscosidade, o uso do PEG 20.000 por exemplo, pode ocasionar problemas de aeração e de dificuldades operacionais no seu manuseio (HADAS, 1976), além de inibir o crescimento de pêlos absorventes no sistema radicular (JACKSON, 1962). No polietileno glicol de peso molecular 6000 (PEG 6000), a solubilidade do oxigênio é de $50 \%$ em relação a sua solubilidade na água, por isso tem sido o mais utilizado em trabalhos com controle da hidratação (HEYDECKER et al., 1973 e 1975; KHAN et al., 1976; HEPPERLY \& SINCLAIR, 1977; GUEDES \& CANTLIFFE, 1980; KHAN et al., 1980/81; KNYPL \& KHAN, 1981; BROCKLEHURST et al., 1987; EIRA, 1988; FU et al., 1988; SILVA, 1989; DELL'AQUILA \& TRITTO, 1990; SHIOGA, 1990; NATH et al., 1991; BINO et al., 1992).

De um modo geral, os resultados obtidos após os ciclos hidratação/secagem têm sido semelhantes aos provenientes do condicionamento osmótico. PERL \& FEDER (1980) concluiram que a hidratação/secagem apresenta vantagens em relação aos procedimentos que envolvem contacto das sementes com produtos químicos: aeração mais adequada, redução da liberação de exsudatos, absorção de menores quantidades de água e sua dispersão uniforme no interior das sementes, controle mais preciso do teor de água das sementes durante o tratamento e maior estabilidade do tratamento (o vigor é mantido em nível elevado durante maior período de tempo). 
41.

Essas conclusões não podem ser consideradas definitivas e devem ser avaliadas em novas pesquisas, porque os trabalhos sobre pré-condicionamento não têm envolvido comparações diretas entre métodos.

\subsubsection{Fatores que Afetam o Condicionamento} Fisiológico

Segundo HEYDECKER \& COOLBEAR (1977), os fatores mais comuns que interferem no condicionamento fisiológico de sementes são:

a) necessidade de controle do suprimento de água para cada semente;

b) manutenção de adequado suprimento de oxigênio;

c) manutenção da temperatura estável;

d) não colonização por microflora patogênica. Outros fatores, como pH do meio e ausência ou presença de luz em quantidade certa, podem ser importantes.

o teor de água em que o reparo é possível deve variar com a composição química das sementes, uma vez que o primeiro é dependente desta, como citam TOLEDO \& MARCos FILHO (1977), bem como a distribuição da água nas diferentes partes da própria semente. As citações são genéricas, havendo trabalhos como o de IBRAHIM \& ROBERTS (1983), que afirmam 
haver atividade de reparo somente acima de $15 \%$ de água para sementes de alface. Já SIMON (1974), admitiu que as membranas assumem a conformidade de bicamada fosfolipídica acima de $20 \%$ de água.

Para a maioria das espécies, a melhor temperatura para o condicionamento varia entre 10 e $20^{\circ} \mathrm{C}$ (BEWLEY \& BLACK, 1985). Para feijão, PANDEY (1988 e 1989), encontrou bons resultados a $25^{\circ} \mathrm{C}$; para soja, $15^{\circ} \mathrm{C}$ (KNYPL \& KHAN, 1981); para amendoim, 20 a $25^{\circ} \mathrm{C}$ (FU et al., 1988) e para alface, 15 a $25^{\circ} \mathrm{C}$ (GUEDES \& CANTLIFFE, 1980).

A baixa temperatura aumenta o período em que as sementes perdem lixiviados quando imersas em água, este fato seria devido à demora ou a fallhas na reorganização dos fosfolipídios das membranas. Assim, OBENDORF \& HOBBS (1970), sugeriram o ajuste do grau de umidade de sementes de soja para $16 \%$ antes da semeadura, o que reduziria a injúria pelo frio devido a reorganização prévia das membranas.

O potencial hídrico normalmente utilizado no condicionamento osmótico com PEG 6000 está na faixa de -5 a -20 bars e a duração do tratamento é de 4 a 35 dias (KHAN et al., 1980/81). A medida em que a temperatura é reduzida, qualquer que seja o potencial hídrico, um tratamento mais longo é necessário. Em contrapartida, em uma dada temperatura, aumentando-se a concentração do soluto (até certo limite), o período de pré-condicionamento é reduzido (BEWLEY \& BLACK, 1985). 
o tempo necessário para que ocorra o reparo nas membranas é curto. BRAMLAGE et al. (1978) obtiveram em menos de 5 minutos o revigoramento de sementes de soja mediante embebição. Porém, os melhores tratamentos são mais longos; para feijão, PANDEY (1988 e 1989) encontrou bons resultados em 48 horas e SHIOGA (1990), superioridade geral nos períodos de 1 a 5 dias.

Muitos fatores afetam o condicionamento, como: - genoma; o estado de vigor e deterioração das sementes; o tempo e a temperatura do tratamento; o tamanho das sementes; a velocidade de absorção de água associada ao potencial mátrico e osmótico do meio; a aplicação de elementos nutritivos, tóxicos ou estimulantes às sementes; o grau de hidratação alcançado pelas sementes e suas partes; a densidade da massa de sementes; a intensidade da luz; a densidade dos gases no ambiente; o tipo de recipiente; se as sementes são ou não secas após o tratamento e o método de secagem; a proteção das sementes contra microrganismos; o suprimento de oxigênio e o número de ciclos de hidratação/secagem (HEGARTY, 1978; KHAN et al., 1978; KHAN et a I. , 1980/81).

Um dos pontos mais controvertidos refere-se aos efeitos da secagem das sementes após o tratamento. Inicialmente ela foi considerada benéfica por HEYDECKER et a 1. (1975) e KHAN et a l. (1978). HANSON (1973) demonstrou que o efeito de "revigoramento" das sementes ocorre no 
período de hidratação, enquanto a secagem o fixa. A-AS-SAQUI \& CORLETo (1978), trabalhando com 4 espécies de sementes forrageiras, encontraram melhores resultados quando as sementes foram embebidas em água por 24 horas e secas em temperatura ambiente até seu peso inicial. Em outros trabalhos, diversos autores consideraram que a secagem reverteu os efeitos benéficos do tratamento (HEYDECKER \& COOLBEAR, 1977; BODSWORTH \& BEWLEY, 1981; SAHA \& BASU, 1981; ARMSTRONG \& MCDONALD, 1992) e, com a ampliação do período de secagem, maior poderá vir a ser a intensidade da reversão (BODSWORTH \& BEWLEY, 1981). Estas observações justificaram as afirmações de HEYDECKER \& WAINWRIGHT (1976), segundo as quais, as sementes devem ser utilizadas imediatamente após o tratamento, para que o processo apresente a máxima vantagem. Deve ser entendido, porém, que a maioria desses autores considerou como reversão do tratamento, a menor velocidade de germinação devido ao maior período de tempo necessário para a embebição, quando submetidas à secagem pós-condicionamento. BROCKLEHURST et al. (1987) ressaltaram outro ponto importante, onde o cuidado com as condições de secagem é que realmente determina a preservação ou não do avanço fisiológico obtido com o "priming". Já MUKHERJEE \& DEY (PATHAK)(1985) mostraram que precauções devem ser tomadas quando a hidratação inicia-se, onde podem ocorrer danos às membranas, caso esta venha a ser muito rápida. 
Outro aspecto da discussão envolve a manutenção dos efeitos do tratamento durante o armazenamento das sementes condicionadas. HANSON (1973) verificou que o efeito de "envigoramento" em sementes de trigo permaneceu estável durante, pelo menos, 4 semanas de armazenamento sob condições normais de ambiente. BROCKLEHURST et al. (1987) trabalhando com sementes de cebola condicionadas, observaram que após 12 meses de armazenamento não houve perda no efeito benéfico do "priming". Resultados promissores, também foram obtidos por KHAN et al. (1976), GUEDES \& CANTLIFFE (1980) e VALDEs et al. (1985). Porém, KNYPL \& KHAN (1981), condicionando sementes de soja, notaram que o desempenho durante o armazenamento tornou-se progressivamente deficiente. Estudos mais detalhados, principalmente quanto à embalagem, ambiente e período de armazenamento apropriados são necessários para a elucidação desses fatos.

\subsubsection{Efeitos do Condicionamento Fisiologico}

Vários pesquisadores relataram resultados promissores com a utilização da técnica de condicionamento fisiológico, destacando-se:

- aumento da velocidade e/ou porcentagem de germinação em: sementes de cenoura e cebola tratadas com PEG 6000 a $15^{\circ} \mathrm{C}$ por 14 dias (HEYDECKER et a $1 ., 1975$ ), sementes de soja tratadas com 30-36\% de PEG 6000 e sementes de amendoim 
e feijão com 20 a $26 \%$ de PEG 6000 (FU et al., 1983), sementes de Vigna radiata embebidas com PEG 6000 na proporção de $1: 5$ por 12 horas e 48 horas (CHIMMAD et al., 1987), sementes de amendoim osmocondicionadas com $20 \%$ de $P E G$ a $15^{\circ} \mathrm{C}$ por 2 dias (FU et al., 1988), sementes de trigo duro embebidas em PEG $6000(-0,37 \mathrm{MPa})$ por 36 horas a $20^{\circ} \mathrm{C}$ (DELL'AQUILA \& TRITTO, $1990)$, sementes de soja tratadas com $20 \%$ de PEG por 48 horas (WANG \& ZHAO, 1990);

- aumento da velocidade de emergência das plântulas (HEYDECKER et al., 1975; KHAN et al., 1980/81), em sementes de soja osmocondicionadas com PEG (HELSEL et al., $1986)$;

- aumento no comprimento e peso da plúmula e raiz primária em sementes de soja osmocondicionadas com PEG $8000(-0,4 \mathrm{MPa})$ por 48 horas a $25^{\circ} \mathrm{C}$, sem secagem posterior (ARMSTRONG \& MCDONALD, 1992).

- maior sincronização do processo de germinação entre sementes do mesmo lote (HEYDECKER et al., 1975; KHAN et al., 1980/ 81), em sementes de soja osmocondicionadas com PEG (HELSEL et al., 1986);

- desenvolvimento mais rápido das plântulas (HEYDECKER \& COOLBEAR, 1977; KHAN et al., 1978; BODSWORTH \& BEWLEY, 1981);

- reparo das membranas celulares diminuindo os efeitos da deterioração: em sementes de soja embebidas em rolos de papel umedecidos com $30 \%$ de PEg 4000 por 8 horas 
(WOODSTOCK \& TAO, 1981), em sementes de couve de Bruxelas ( $1 \mathrm{~g})$ imersas em $25 \mathrm{ml}$ de água por 3 horas, a temperatura ambiente $\left(23^{\circ} \mathrm{C}\right)$ e, posteriormente secas (BURGASS \& POWELL, 1984), em sementes de soja condicionadas sobre 4 folhas de papel-toalha ( $150 \mathrm{~mm}$ de diâmetro) embebidas com $20 \mathrm{ml}$ de água por 2 dias a $25^{\circ} \mathrm{C}$ e, posteriormente secas (TILDEN \& WEST, 1985), em sementes de soja tratadas com PEG (GAO et al., 1988), em sementes de feijão com 2 anos condicionadas sobre 5 folhas de papel-toalha (150 mm de diâmetro) umedecidas com água destilada por 48 horas a $25^{\circ} \mathrm{C} e$, posteriormente secas (PANDEY, 1988), em sementes de soja tratadas com PEG a $40 \%$ por 24 a 48 horas (MENG \& LI, 1992);

- maior resistência a condições de estresse durante a germinação (principalmente baixas temperaturas): em sementes de couve de Bruxelas tratadas com PEG $6000(-11,9$ bars) a $15^{\circ} \mathrm{C}$ por 11 dias (KHAN et al,, 1980/81), sementes de soja osmocondicionadas com PEG $6000(-8,6$ a $-11,9$ bars $)$ por 4 a 8 dias a $15^{\circ} \mathrm{C}$ e, posteriormente secas (KNYPL \& KHAN, 1981), sementes de Brassica oleracea tratadas com PEG 8000 a $25^{\circ} \mathrm{C}$ (RAO et a 1., 1987), sementes de milho condicionadas com PEG (BASRA et a 1., 1988), sementes de alface condicionadas com manitol a $-8,4$ atm por 4 dias a $20^{\circ} \mathrm{C}$ (EIRA, 1988), sementes de soja osmocondicionadas com PEG (LORENZ et al., $1988)$;

- aumento do vigor (revigoramento) (KHAN et a 1., 1976): em sementes de soja tratadas com $30-36 \%$ de PEG 
6000 e sementes de amendoim e feijão com 20 a $26 \%$ de PEG 6000 (FU et al., 1983), sementes de amendoim osmocondicionadas com $20 \%$ de PEG a $15^{\circ} \mathrm{C}$ por 2 dias (FU et al, 1988), em sementes de feijão com 1,2 e 3 anos condicionadas sobre 5 folhas de papel-toalha (150 mm de diâmetro) umedecidas com $20 \mathrm{ml}$ de água destilada por 48 horas a $25^{\circ} \mathrm{C}$ e, posteriormente secas (PANDEY, 1988), sementes de tomate condicionadas em $\mathrm{KNO}_{3}+$ $\mathrm{K}_{2} \mathrm{HPO}_{4}$ por 5 dias a $20^{\circ} \mathrm{C}$ (ARGERICH et al., 1989), sementes de soja submetidas a lenta embebição em atmosfera saturada por 24 horas e, posteriormente imersas em água por 2 horas e novamente secas (SAHA et a 1., 1990);

- emergindo mais rapidamente, as plântulas poderão competir mais eficientemente com as invasoras e permitir que a aplicação de herbicidas de pós-emergencia seja mais eficiente (HEYDECKER et al., 1975; KHAN et al., 1976);

- em climas quentes, a água pode evaporar da superfície de um canteiro inicialmente molhado antes que as sementes tenham tempo suficiente para germinar, o que pode ser solucionado com o condicionamento fisiologico das sementes, já que resulta em germinação quase imediata após o plantio (HEYDECKER et al., 1975);

- pode haver aumento da "taxa de repicagem" e também da "taxa de retorno" de plantas que necessitam ser cultivadas em estufa ou ambiente controlado (HEYDECKER et al., 1975; KHAN et al., 1976; BRADFORD, 1986); 
- durante o período de condicionamento, muitas sementes dormentes podem deixar essa condição e germinarem imediatamente após a semeadura (isso parece ser devido à redução dos níveis de ABA nas sementes durante o tratamento) (HEYDECKER et a 1., 1975; KHAN et a $1 ., 1980 / 81$ );

- aumento da produção (BASU, 1976; Corleto \& A-As-Saquil citado por SAVINO et al., 1979; KHAN et al., $1980 / 81 ;$ BRADFORD, 1986);

- redução da saída de eletrólitos (decréscimo no valor do teste de condutividade elétrica); (TILDEN \& WEST, 1985 ; PANDEY, 1988; WANG \& ZHAO, 1990; MENG \& LI, 1992);

- aumento da replicação do DNA antes da germinação em sementes de tomate condicionadas com PEG 6000 $(-1,0 \mathrm{MPa})$ por 14 dias (BINO et al., 1992);

- prolonga o tempo de armazenamento das sementes (BASU, 1976);

- redução na produção de peróxidos em sementes de soja (GAO et al., 1988);

- permite o estudo mais efetivo dos componentes do processo de germinação (HEYDECKER et al., $1975)$

${ }^{1}$ CORLETO, A. \& A-AS-SAQUI, M. Influenza della tecnica del "presoaking" dei semi e di differenti periodi di mancanza di acqua disponibile nel terreno sulla produzione del sorgo da granella. X Simp. Inter. Agron., 20-24; 256-68, 1974. 
Por outro lado, vários pesquisadores não encontraram respostas quanto:

- aumento na porcentagem de germinação: em sementes de soja imersas em água por 30 minutos seguido de secagem (HEPPERLY \& SINCLAIR, 1977), sementes de feijão condicionadas em folha de papel umedecidos com água por 48 horas a $25^{\circ} \mathrm{C}$ (PANDEY, 1988);

- aumento na longevidade das sementes: em alface tratadas com PEG $8000(-1,5 \mathrm{MPa})$ por vários períodos (TARQUIS \& BRADFORD, 1992);

- aumento do vigor: em sementes novas de feijão condicionadas em papel umedecido com $20 \mathrm{ml}$ de água por 48 horas a $25^{\circ} \mathrm{C}$ e posteriormente secas (PANDEY, 1988);

- aumento da produção: em sementes de pimentão, berinjela e pepino, condicionadas com manitol (PASSAM et al., 1989), sementes de tomate e cebola, osmocondicionadas com PEG $8000(-5,8$ e $-14,9$ bars $)$ por 1 a 4 semanas (ALI et al., 1990).

As melhores respostas ao condicionamento foram obtidas em sementes pequenas ou com embrióes pequenos por MUHYADDIN \& WIEBBE (1989). Por outro lado, a técnica de condicionamento fisiológico, baseada no controle da hidratação das sementes, indica potencialidades para o seu desenvolvimento em função dos resultados positivos encontrados por diversos pesquisadores; entretanto, sua utilização em escala comercial depende ainda da definição da 
51.

melhor metodologia para cada espécie e do desenvolvimento de um método prático e de baixo custo, aeróbico e com a supressão da colonização das sementes por microrganismos (HEYDECKER et a l., 1975; HEYDECKER, 1977; BRADFORD, 1986). 
52.

\section{MATERIAL E MÉTODOS}

A pesquisa foi conduzida no Laboratório de Sementes do Departamento de Agricultura da Escola Superior de Agricultura "Luiz de Queiroz" (LAG/ESALQ/USP), com a colaboração do Departamento de Ciência e Tecnologia Agroindustrial (LCT/ESALQ/USP) durante o período de julho de 1992 a maio de 1993. O ensaio foi realizado com lotes de sementes de soja cultivar IAC-8, recomendado para o Estado de São Paulo; esses lotes apresentaram poder germinativo compatível com as exigências mínimas para a comercialização e diferenças quanto ao vigor.

\subsection{Caracterização dos Lotes}

Foram recebidos em julho de 1992 , quatro lotes de sementes básicas provenientes do Instituto Agronômico de Campinas. Os lotes foram submetidos a verificação da classificação pelo tamanho das sementes, utilizando-se peneiras de crivos oblongos; a maior concentração da retenção de sementes ocorreu na peneira $13 \times 3 / 4^{\prime \prime}$. 
Após a recepção, as sementes de cada lote foram homogeneizadas em divisor centrífugo modelo Boerner e divididas em quatro repetições; amostras também foram separadas para os testes de caracterização da qualidade física, fisiológica e sanitária, conduzindo-se os seguintes testes:

\subsubsection{Pureza Física}

A amostra $(500 \mathrm{~g})$ de cada lote foi examinada cuidadosamente e separada em seus componentes: sementes puras, outras sementes e material inerte. A seguir foram efetuadas as pesagens e os cálculos, sendo o resultado expresso em porcentagem em peso das sementes puras. A metodologia dessa análise seguiu as Regras para Análise de Sementes (BRASIL, 1980).

\subsubsection{Germinação}

Conduzido com quatro repetições de 50 sementes por lote, em germinador a $28^{\circ} \mathrm{C}$, utilizando rolos de papeltoalha umedecidos com quantidade de água equivalente a 2,2 vezes o seu peso. As contagens foram efetuadas aos 4 e 7 dias após a semeadura, computando-se as porcentagens de plântulas normais, anormais e sementes não germinadas, 
segundo os critérios estabelecidos pelas Regras para Análise de sementes (BRASIL, 1980).

\subsubsection{Envel hecimento Acelerado}

Realizado com a utilização de "gerbox" adaptado, a $41^{\circ} \mathrm{C}+100 \%$ U.R., durante 48 horas. Em seguida, foi instalado o teste de germinação, conforme descrição em 3.1.2., sendo a contagem de plântulas normais efetuada no quarto dia após a semeadura, segundo as recomendações relatadas por MARCos FILHO et al. (1987), para o método do gerbox.

\subsubsection{Condutividade Eletrica}

Quatro repetições de 50 sementes fisicamente puras, previamente pesadas, foram embebidas em $75 \mathrm{ml}$ de água destilada e mantidas em germinador regulado a $25^{\circ} \mathrm{C}$, durante 24 horas, de acordo com LOEFfler et al. (1988). A leitura da condutividade foi efetuada em aparelho Digimed CD-20, com resultados expressos em $\mu m h o s / \mathrm{cm} / \mathrm{g}$.

\subsubsection{Emergência das Plântulas em Campo}

Conduzido com quatro repetições de 50 sementes distribuidas em sulcos de $2,0 \mathrm{~m}$ de comprimento e 0,05 m de 
profundidade distantes $0,3 \mathrm{~m}$ entre $\mathrm{si}$; a cobertura das sementes foi efetuada com aproximadamente $0,02 \mathrm{~m}$ de terra. A contagem da emergência das plântulas foi efetuada 21 dias após a semeadura e, os dados expressos em porcentagem. Considerou-se como plântula emergida, o estádio de emergência (VE) de FEHR \& CAVINESS (1980), onde os cotilédones se apresentam acima da superfície do solo.

\subsubsection{Sanidade}

Determinada de acordo com o método do papel de filtro (LUCCA FILHO, 1987), através da incubação de vinte repetições de 10 sementes/lote, a $20^{\circ} \mathrm{C}$ durante 7 dias, com alternância luz fluorescente/escuro (em turnos de 12 horas). A porcentagem e a identidade dos microrganismos encontrados foram determinadas com o auxílio de microscópio estereoscópico.

\subsubsection{Grau de Umidade}

Determinado de acordo com o procedimento descrito nas Regras para Análise de Sementes (BRASIL, 1980), a $105 \pm 3^{\circ} \mathrm{C}$ durante 24 horas. O teor de água foi expresso com base no peso úmido das sementes.

Os resultados dos testes de caracterização das sementes de soja IAC-8 são apresentados na Tabela 1. 
Tabela 1 - Caracterização dos lotes de sementes de soja (Glycine max (L.) Merril), cultivar IAC-8.

Parâmetros

Lote I Lote II Lote III Lote IV

\begin{tabular}{|c|c|c|c|c|}
\hline Pureza física(\%) & 99,8 & 99,8 & 99,7 & 99,6 \\
\hline Germinação (\%) & 91 & 93 & 92 & 95 \\
\hline Env. Ace $1 .(\%)$ & 85 & 91 & 83 & 90 \\
\hline $\begin{array}{l}\text { Cond. Elet. } \\
(\mu \mathrm{mhos} / \mathrm{cm} / \mathrm{g})\end{array}$ & 75,02 & 63,33 & 68,84 & 62,57 \\
\hline Emergência (\%) & 86 & 88 & 87 & 86 \\
\hline \multicolumn{5}{|l|}{ Sanidade (\%) } \\
\hline Phomopsis sojae & 1,0 & 0,5 & 2,0 & 3,0 \\
\hline Cercospora sojina & 0,0 & 0,0 & 1,0 & 1,0 \\
\hline Aspergillus spp & 0,5 & 1,5 & 1,5 & 2,0 \\
\hline Penicillium spp & 2,0 & 1,0 & 0,5 & 2,5 \\
\hline Fusarium spp & 3,5 & 0,5 & 3,5 & 3,0 \\
\hline Grau de umidade(\%) & 10,2 & 9,7 & 11,1 & 11,0 \\
\hline
\end{tabular}

Esses dados mostram que os diversos lotes foram semelhantes, tanto em relação à qualidade fisiológica como à sanitária. Existe, porém, pequena desvantagem dos lotes I e III nos testes de envelhecimento acelerado e de condutividade elétrica. 


\subsection{Obtenção dos Tratamentos}

Os lotes permaneceram armazenados, durante aproximadamente 35 dias, em condições normais de ambiente, para uniformização do grau de umidade das sementes.

Para obtenção dos tratamentos, além da testemunha não condicionada, os seguintes procedimentos foram adotados:

\subsubsection{Hidratação Lenta}

As sementes foram tratadas com a mistura dos fungicidas Thiabendazol (Tecto 100) e Thiram (Rhodiauran 70) na dosagem de $17+73 \mathrm{~g}$ do ingrediente ativo por $100 \mathrm{~kg}$ de sementes (HENNING et a 1, 1992). Foram utilizadas $900 \mathrm{~g}$ de sementes por lote, de cada tratamento, por repetição, colocadas entre duas camadas de papel-toalha, dispostas sobre bandejas de $50 \times 47 \mathrm{~cm}$ no interior de germinador a $20^{\circ} \mathrm{C}$ constantes. Os períodos de embebição utilizados foram: 12 , 18 e 24 horas; cada camada de substrato era constituida por 6 folhas de papel-toalha, ocupava toda a superfície da bandeja e foi umedecida com quantidade de água equivalente a 2,5 vezes o peso do substrato.

Vencidos os períodos pré-determinados para cada tratamento, foram coletadas amostras para determinação do grau de umidade, qualidade fisiológica e composição 
química. O material restante foi submetido a secagem (distribuído em bandejas maiores) em ambiente naturalmente ventilado, até atingir o grau de umidade próximo ao verificado na pré-embebição; após a secagem, cada tratamento foi também amostrado e avaliado quanto aos mesmos aspectos já citados. Posteriormente, foi colocado em sacos de papel kraft e armazenado sob condições normais de ambiente, aguardando as avaliações após 3 e 6 meses de armazenamento pós-condicionamento.

\subsubsection{Condicionamento em Solução Osmótica}

Foram empregadas soluções de polietileno glicol (PEG 6000) de modo a serem desenvolvidos potenciais hídricos de -6 e -8 atm ( $1 \mathrm{MPa}=10 \mathrm{bar}=9,87 \mathrm{~atm})$. Todas as soluções foram preparadas em água destilada e as quantidades de soluto para a obtenção dos potenciais hídricos tiveram, como base de cálculo, a formula desenvolvida por MICHEL \& KAUFMANN (1973).

$$
\begin{aligned}
\Psi \mathrm{h}=-\left(1,18 \times 10^{-2}\right) \mathrm{C} & -\left(1,18 \times 10^{-6}\right) \mathrm{C}^{2}+\left(2,67 \times 10^{-4}\right) \mathrm{CT}+ \\
+ & \left(8,39 \times 10^{-7}\right) \mathrm{C}^{2} \mathrm{~T}
\end{aligned}
$$

Onde:

$$
\begin{aligned}
& T_{h}=\text { potencial hídrico da solução (atm) } \\
& \mathrm{C}=\mathrm{g} \text { de } \mathrm{PEG} 6000 / \mathrm{kg} \mathrm{H}_{2} \mathrm{O}(\mathrm{a} \text { ser calculado) } \\
& \mathrm{T}=\text { temperatura em }{ }^{\circ} \mathrm{C}\left(20^{\circ} \mathrm{C}\right)
\end{aligned}
$$


A dissolução do PEG em água destilada foi efetuada em um agitador mecânico com um dia de antecedência à fase experimental.

As sementes já tratadas com fungicida $(900 \mathrm{~g})$, foram distribuídas entre camadas de papel-toalha, conforme descrição em 3.2.1. e o substrato umedecido com a solução de PEG adequada, equivalente a 2,5 vezes o peso do substrato. o condicionamento foi conduzido em germinador, a $20^{\circ} \mathrm{C}$, durante 4 dias, as sementes não foram lavadas. Vencido este período, as sementes foram amostradas para avaliação do grau de umidade, os demais procedimentos foram relatados na hidratação lenta (3.2.1.).

As sementes condicionadas foram avaliadas ainda úmidas, logo após a secagem e depois de armazenadas por 3 e 6 meses, além da testemunha não condicionada. Um resumo dos tratamentos encontra-se na Tabela 2 .

Tabela 2 - Tratamentos empregados.

\begin{tabular}{lll}
\hline & $\begin{array}{c}\text { HIDRATAÇÃo } \\
\text { LENTA }\end{array}$ & $\begin{array}{c}\text { CONDICIONAMENTO } \\
\text { OSMÓTICO }\end{array}$ \\
\hline \multirow{3}{*}{ Testemunha } & H-12 hs & PEG -8 atm \\
& $\cdot$ H-18 hs & PEG -6 atm \\
\hline
\end{tabular}


60.

3.3. Avaliação dos Efeitos dos Tratamentos

Foram efetuadas as seguintes determinações:

3.3.1. Grau de Umidade

Determinado como o relatado em 3.1 .7$, com 2 repetições/tratamento/lote.

\subsubsection{Qualidade Fisiológica}

Os testes de germinação, envelhecimento acelerado, condutividade eletrica e emergência das plântulas em campo seguiram as mesmas descrições apresentadas em $3.1 .2 ., 3.1 .3 ., 3.1 .4$ e 3.1 .5 . utilizando-se 4 repetições/tratamento/lote.

\subsubsection{Composição Química das Sementes}

Avaliada com a colaboração do Departamento de Ciência e Tecnologia Agroindustrial, ESALQ/USP, através das determinações:

a) Teor de óleo: determinado pela extração com hexano em extrator de Butt, segundo a Norma Italiana NGD B-4 (Stazione sperimentale per le Industrie degli oli e dei Grassi - SSOG, 1976). Os resultados foram expressos em porcentagem de matéria seca. 
b) Indice de acidez: determinado no óleo, através da metodologia NGD C-10 (SSOG, 1976), sendo os resultados expressos em $\mathrm{mg} \mathrm{KOH} / \mathrm{g}$.

c) fndice de peróxido: determinado também no óleo pelo método NGD C-35 (SSOG, 1976), sendo os resultados expressos em meq $\mathrm{O}_{2} / 1000 \mathrm{~g}$.

d) Proteína bruta: o teor de nitrogênio total das sementes foi determinado através do método de microKjeldhal (Association of official Analytical Chemists - AOAC, $1984)$, e os resultados multiplicados pelo fator 6,25 e expressos em porcentagem de matéria seca.

e) Açúcares totais solúveis em álcool: os açúcares foram extraídos através do método de SHANNON (1963) com algumas modificações. A sua quantificação foi realizada pelo método fenol-ácido sulfúrico descrito por DUBoIs et al. (1956) com leitura do valor da absorbância em espectrofotômetro a $490 \mathrm{~nm}$ e comparação com uma curva padrão de glicose; os resultados foram expressos em $\mathrm{mg} / \mathrm{g}$.

f) Açúcares redutores: determinado através do método de NELSON (1944) com os reagentes de Somogyi e Nelson e leitura em espectrofotometro a $530 \mathrm{~nm}$ para determinação da absorbância das amostras. O cálculo do teor de açúcares redutores foi realizado por interpolação dos valores das leituras em uma curva padrão de glicose e os resultados expressos em $\mathrm{mg} / \mathrm{g}$. 


\subsection{Procedimento Estatístico}

A análise dos dados foi efetuada, separadamente para os testes de avaliação da qualidade fisiológica e análise da composição química e em cada época, usando-se o Sistema de Análise Estatística para Microcomputadores SANEST (ZONTA et al., 1984). Os dados correspondentes à determinação do grau de umidade não foram anal isados estatisticamente.

o delineamento experimental utilizado para os testes de avaliação da qualidade fisiológica em cada época, foi o fatorial lotes $x$ tratamentos, com quatro repetições, dentro do esquema de análise de variância apresentado na Tabela 3 .

Tabela 3 - Esquema de análise de variância dos dados obtidos nos testes de avaliação da qualidade fisiológica das sementes para cada época.

\begin{tabular}{ll}
\hline C.V. & G.L. \\
\hline LOTES (L) & 03 \\
TRATAMENTOS (T) & 05 \\
L X T & 15 \\
RES IDUO & 72 \\
\hline TOTAL & 95 \\
\hline
\end{tabular}


Para as análises de composição química, o delineamento experimental foi o fatorial lotes $x$ tratamentos $x$ épocas, segundo o esquema de análise da variância apresentado na Tabela 4.

Os dados de germinação, envelhecimento acelerado, emergência das plântulas em campo, teor de óleo e proteína bruta, foram transformados em arc sen $\sqrt{\mathrm{X} / 100}$, e o índice de peróxido em $\log (x+1)$.

Tabela 4 - Esquema de análise da variância dos dados de composição química.

C.V.

G. L.

LOTES (L)

03

TRATAMENTOS

( $\mathrm{T})$

05

ÉPOCAS (E)

03

L $\times \mathrm{T}$

15

$\mathrm{L} \times \mathrm{E}$

09

$\mathrm{T} \times \mathrm{E}$

15

RES IDUO

45

TOTAL 
64 .

\title{
4. RESULTADOS E DISCUSSÃO
}

\author{
4.1. Epoca I
}

4.1.1. "Sem Secagem Após Condicionamento"

4.1.1.a. Grau de Umidade

Os dados referentes à determinação do grau de umidade das sementes não foram analisados estatisticamente; os resultados obtidos logo após os diversos tratamentos de condicionamento fisiológico estão contidos na Tabela 5.

Os dados mostram que todos os tratamentos utilizados alcançaram valores acima de $20 \%$ de água, já que segundo SIMON (1974) este é o valor mínimo para que as membranas celulares assumam a conformidade de bicamada fosfolipídica, readquirindo a permeabilidade seletiva; abaixo de $20 \%$ de água as membranas estão porosas sujeitas a lixiviação de solutos (LUZzATI \& HUSSON, 1962; SENARATNA et al., 1985). 
Tabela 5 - Grau de umidade: valores médios (\%) obtidos para os quatro lotes de sementes de soja apos os tratamentos de condicionamento fisiológico. Piracicaba, 1992 .

\begin{tabular}{lrrrrr}
\hline \multirow{2}{*}{ Tratamentos } & \multicolumn{5}{c}{ LOTES } \\
\cline { 2 - 6 } & L I & L I I & L I I I & L IV & Média \\
\hline Testemunha & 9,7 & 10,1 & 9,7 & 10,1 & 9,9 \\
H-12 h & 25,2 & 25,7 & 25,4 & 25,8 & 25,5 \\
H-18 h & 27,7 & 27,7 & 27,4 & 27,5 & 27,6 \\
H-24 h & 30,5 & 30,7 & 30,5 & 30,7 & 30,6 \\
PEG -8atm & 32,2 & 31,8 & 31,8 & 31,9 & 31,9 \\
PEG -6atm & 33,5 & 34,2 & 33,4 & 33,7 & 33,7 \\
\hline
\end{tabular}

Os primeiros momentos da embebição são os mais críticos, podendo inclusive ocorrer danos severos às membranas caso o processo seja muito rápido (PARRISH \& LEOPOLD, 1977), principalmente em sementes com menos de $13 \%$ de água (HOBBS \& OBENDORF, 1972), valor este observado em todas as testemunhas dos lotes empregados, justificando os cuidados para que a embebição se processasse de maneira lenta, no presente trabalho.

Nas primeiras doze horas de embebição, o ganho porcentual de água por hora é superior ao dos periodos subsequentes. Durante este período de embebição, o teor de água médio de sementes elevou-se de 9,9\% (testemunha) para $25,5 \%$, o que representa um acréscimo de $1,3 \%$ de água por 
66 .

hora. Nos demais períodos (H-18 e H-24h), o acréscimo foi de 0,4 e $0,5 \%$ de água por hora. Segundo o padrão trifásico de embebição proposto por BEWLEY \& BLACK (1983), a fase I seria inicialmente muito rápida, dấ o acréscimo de $1,3 \%$ de água por hora no tratamento, $\mathrm{H}-12 \mathrm{~h}$; a partir daí a semente ainda exibe ganhos, porém menores $(0,4-0,5 \%$ água/hora). Ao atingir $35-40 \%$ de água teria início a fase II, onde a absorção de água é pouco evidente (CARVALHO \& NAKAGAWA, 1988), já a germinação só ocorreria na fase III após 24 h de hidratação (ARMSTRONG \& MCDONALD, 1992) estando as sementes de soja com 50 - 55\% de água segundo BURCH \& DELOUCHE (1959) e PESKE \& DELOUCHE (1985) ou com $650 \mathrm{~g} \mathrm{H}_{2} \mathrm{O} / \mathrm{kg}$ de peso fresco (ARMSTRONG \& MCDONALD, 1992); fase esta onde a desidratação não é mais tolerada pelo embrião.

Os tratamentos correspondentes ao condicionamento com soluções osmóticas, proporcionaram embebições mais lentas; em 4 dias (96 horas), os lotes de sementes hidratados em papel toalha embebido com solução com potencial de -8 atm, atingiram teores de água muito próximos aos do tratamento $\mathrm{H}-24 \mathrm{~h}$. O tratamento PEG - 6atm, apesar de possuir o potencial osmótico menos negativo, não proporcionou um ganho expressivo no teor de água $(33,7 \%)$ quando comparado com o potencial de -8 atm $(31,9 \%)$, indicando possivelmente o início da fase I I da embebição, onde os ganhos de água são quase nulos. 
Portanto, de acordo com o que foi proposto por HEYDECKER \& COOLBEAR (1977) todos os lotes submetidos ao condicionamento fisiológico atingiram, no máximo, a fase II da embebição.

\subsection{1.b. Qualidade Fisiologica}

Os resultados da análise de variância, representados pela significâcia do teste $F$, para as variáveis utilizadas na avaliação da qualidade fisiológica das sementes logo após o condicionamento fisiológico, são apresentados na Tabela 6 .

Tabela 6 - Significâncias do Teste $F$ referentes às determinações para a avaliação do desempenho das sementes logo após o condicionamento fisiológico. Piracicaba, 1992 .

Causas da Variação

Teste

\begin{tabular}{cccc}
\hline Germinação & $\begin{array}{c}\text { Envelhecimento } \\
\text { Acelerado }\end{array}$ & $\begin{array}{c}\text { Condutividade } \\
\text { Elétrica }\end{array}$ & $\begin{array}{c}\text { Emergência } \\
\text { das Plântulas } \\
\text { em Campo }\end{array}$ \\
\hline
\end{tabular}

\section{Lotes}

Tratamentos

NS

Lotes $x$ Trat. NS

$* *$
$* *$

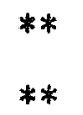

**

NS

NS

**

NS

NS - não significativo

* - significativo ao nível de $5 \%$ de probabilidade ** - significativo ao nível de $1 \%$ de probabilidade 
Portanto, os parâmetros que refletem o vigor, apresentaram maior sensibilidade às causas da variação. o teste de germinação não mostrou diferenças entre as causas da variação, já que esse teste não é eficiente na detecção dos estágios iniciais do processo de deterioração de sementes (TOLEDO \& MARCOS FILHO, 1977), que resultam em perda do vigor (DELOUCHE \& BASKIN, 1973 ).

A Tabela 7, referente à comparação das médias de germinação e de envelhecimento acelerado, mostrou diferenças estatísticas entre tratamentos e lotes apenas no parâmetro envelhecimento acelerado. o valor médio mais elevado foi observado para a testemunha, que não diferiu de H-12 h. As médias dos tratamentos com solução osmótica (PEG -8 e PEG -6atm), foram inferiores as de hidratação com água (H-12, H-18 e H-24 h), apesar de PEG -6atm não diferir de H18 e H-24 h. Quanto aos lotes, as médias de L II e L IV foram superiores às demais, não diferentes de L III.

o teste de germinação não acusou efeito de condicionamento; médias inferiores foram obtidas em todos os tratamentos submetidos ao teste de envelhecimento acelerado. Apesar disso, algumas combinações de tratamentos com sementes de lotes mais vigorosos suportaram o estresse, mesmo estando com grau de umidade mais elevado (até $33,7 \%$ no tratamento PEG $-6 a(m)$, antes de iniciado o teste de envelhecimento. Sabe-se que sementes mais úmidas, em geral, são mais sensíveis às condições do teste, já que apresentam atividade metabólica intensificada (MARCOS FILHO et a $1 ., 1987$ ). 
Tabela 7 - Germinação e envelhecimento acelerado: comparação de valores médios de lotes e tratamentos após condicionamento fisiológico (sementes ainda úmidas). Piracicaba, 1992.

\begin{tabular}{|c|c|c|c|c|c|c|c|c|c|c|}
\hline \multirow{2}{*}{ Tratamento } & \multicolumn{5}{|c|}{ Germinação (\%) } & \multicolumn{5}{|c|}{ Envelhecimento Ace lerado (\%) } \\
\hline & L I & L II & L III & L IV & $\overrightarrow{\mathrm{M}}$ & L I & L I I & $L I I I$ & L IV & $\bar{M}$ \\
\hline Test. & 95 & 96 & 94 & 96 & $95^{\AA}$ & 85 & 95 & 91 & 93 & $91^{A}$ \\
\hline $\mathrm{H}-12 \mathrm{~h}$ & 96 & 99 & 96 & 97 & $97^{A}$ & 86 & 91 & 87 & 92 & $89^{A B}$ \\
\hline $\mathrm{H}-18 \mathrm{~h}$ & 92 & 95 & 96 & 96 & $95^{\AA}$ & 80 & 89 & 87 & 83 & $85^{B C}$ \\
\hline $\mathrm{H}-24 \mathrm{~h}$ & 93 & 97 & 92 & 95 & $94^{A}$ & 85 & 86 & 85 & 90 & $87^{\mathrm{BC}}$ \\
\hline PEG-8atm & 96 & 98 & 93 & 97 & $96^{h}$ & 80 & 82 & 72 & 77 & $78^{D}$ \\
\hline PEG-6atm & 95 & 98 & 98 & 95 & $97^{A}$ & 77 & 83 & 84 & 90 & $83^{60}$ \\
\hline Médias & $95^{\natural}$ & $97^{\mathrm{a}}$ & $95^{a}$ & $96^{d}$ & & $82^{6}$ & $88^{a}$ & $85^{a b}$ & $88^{8}$ & \\
\hline C.V. \% & 6,3 & & & & & 6 , & & & & \\
\hline
\end{tabular}

Médias seguidas da mesma letra, minúsculas (nas linhas) e maiúsculas (nas colunas), não diferem entre si pelo teste de Tukey, ao nível de $5 \%$ de probabilidade.

O teste de condutividade elétrica (Tabela 8) forneceu resultados divergentes dos obtidos para o envelhecimento acelerado. Quanto mais úmidas, melhor o desempenho das sementes; os tratamentos PEG -6atm $(33,7 \%)$ e PEG $-8 \operatorname{atm}(31,9 \%)$ não diferiram e apresentaram superioridade aos demais. Este fato é amplamente discutido na literatura, onde vários trabalhos estabelecem a relação entre a quantidade de água nas sementes e a organização das membranas; quando secas as membranas estão desorganizadas adquirindo forma hexagonal, o que facilita a saída de 
eletrólitos; com a reidratação as membranas se reorganizam, retornando à forma lamelar, reduzindo a saída de eletrólitos em função do reparo celular (SIMON, 1974; WEBSTER \& LEOPOLD, 1977; BRAMLAGE et al., 1978; WOODSTOCK \& TAO, 1981; SIMON \& MILLS, 1983; FU et a ., 1988; PANDEY, 1988).

Foi notado um certo agrupamento das médias dos efeitos dos tratamentos no teste de condutividade, de acordo com o grau de umidade alcançado pela semente após o condicionamento fisiológico. De um modo geral, os melhores tratamentos foram os que atingiram os teores de água mais elevados (PEG - 6atm e PEG - $8 \mathrm{~atm}$ ); num segundo grupo aparecem os tratamentos $\mathrm{H}-24 \mathrm{~h}(30,6 \%$ de água $)$ e $\mathrm{H}-18 \mathrm{~h}(27,6 \%)$ e, finalmente, $\mathrm{H}-12 \mathrm{~h}$ com $25,5 \%$ de água, que mostrou-se superior apenas a testemunha com $9,9 \%$ de água.

Resultados anteriores, de caracterização dos lotes (Tabela 1), indicaram a existência de dois grupos de qualidade fisiológica distintas, um com vigor mais elevado (L II e IV) e outro inferior ( $L$ I e III). Porém, realizado o condicionamento fisiológico não foi possível a separação de lotes, havendo uma uniformização da qualidade, confirmando as observações de DELL'AQUila \& TRITTO (1990); estes autores afirmaram que a resposta ao tratamento foi dependente do grau de deterioração da semente, sendo o envigoramento ou reparo somente notados em sementes deterioradas ou com baixo vigor (SAVINO et al., 1979; WARD \& POWELL, 1983; BURGASS \& POWELL, 1984). PANDEY (1988) também sugeriu a existência de um estado ou ponto crítico de deterioração, onde a partir do qual a viabilidade não pode ser mais restaurada. 
Tabela 8 - Condutividade eletrica e emergência das plântulas: comparação de valores médios de lotes e tratamentos após condicionamento fisiológico (sementes ainda úmidas). Piracicaba, 1992 .

\begin{tabular}{|c|c|c|c|c|c|}
\hline \multirow{2}{*}{ Tratamento } & \multicolumn{5}{|c|}{ Condutividade Elétrica ( $\mu$ mhos $/ \mathrm{g} / \mathrm{cm}$ ) } \\
\hline & L I & L I I & L III & L IV & $\bar{M}$ \\
\hline Testemunha & $80,51^{\mathrm{Db}}$ & $66,51^{\mathrm{Da}}$ & $77,31^{\mathrm{cb}}$ & $70,16^{\mathrm{Da}}$ & 73,62 \\
\hline$H-12 h$ & $46,95^{\mathrm{Ca}}$ & $43,03^{\mathrm{Ca}}$ & $44,46^{\mathrm{Ba}}$ & $44,46^{\mathrm{ca}}$ & 44,72 \\
\hline$H-18 h$ & $41,80^{\mathrm{BCa}}$ & $39,13^{\mathrm{BCa}}$ & $41,09^{\mathrm{Ba}}$ & $38,76^{\mathrm{BCa}}$ & 40,20 \\
\hline$H-24 h$ & $43,08^{\mathrm{BCa}}$ & $41,94^{\mathrm{ca}}$ & $41,20^{\mathrm{Ba}}$ & $40,76^{\mathrm{BCa}}$ & 41,74 \\
\hline $\mathrm{PEG}-8 \mathrm{~atm}$ & $37,83^{\mathrm{ABa}}$ & $33,56^{\mathrm{ABa}}$ & $33,48^{\mathrm{Aa}}$ & $33,55^{\mathrm{Aa}}$ & 34,36 \\
\hline $\mathrm{PEG}-6 \mathrm{~atm}$ & $35,64^{\mathrm{Aa}}$ & $30,77^{\mathrm{Aa}}$ & $32,55^{\mathrm{Aa}}$ & $34,86^{\mathrm{ABa}}$ & 33,45 \\
\hline \multicolumn{6}{|c|}{ Médias $47,63 \quad 42,49 \quad 45,01 \quad 43,59$} \\
\hline C.V. \% & 6,39 & & & & \\
\hline \multirow{2}{*}{ Tratamento } & \multicolumn{5}{|c|}{ Emergência de plântulas em Campo (\%) } \\
\hline & $\mathrm{L} \quad \mathrm{I}$ & L I I & L I I I & L IV & $\bar{M}$ \\
\hline Testemunha & 87 & 94 & 88 & 93 & $91^{A}$ \\
\hline $\mathrm{H}-12 \mathrm{~h}$ & 92 & 95 & 95 & 93 & $94^{\mathrm{A}}$ \\
\hline$H-18 h$ & 90 & 98 & 93 & 90 & $93^{A}$ \\
\hline$H-24 h$ & 87 & 92 & 95 & 93 & $94^{A}$ \\
\hline PEG-8atm & 90 & 95 & 95 & 92 & $92^{\mathrm{A}}$ \\
\hline PEG-6atm & 87 & 85 & 94 & 91 & $92^{\mathrm{A}}$ \\
\hline Médias & $89^{b}$ & $95^{\mathrm{a}}$ & $93^{a}$ & $92^{\mathrm{ab}}$ & -- \\
\hline C.V. $\%$ & 7,10 & & & & \\
\hline
\end{tabular}

Médias seguidas da mesma letra, minúsculas (nas linhas) e maiúsculas (nas colunas), não diferem entre si pelo teste de Tukey, ao nível de $5 \%$ de probabilidade. 
A testemunha não condicionada (Tabela 8) apresentou diferenças estatísticas entre lotes, confirmando a existência de dois grupos de sementes, L I e L III com desempenho inferior, e L II e L IV com um melhor desempenho. No parâmetro emergência das plântulas em campo (Tabela 8), não houve diferença estatística entre os tratamentos, não caracterizando o efeito de condicionamento; quanto aos lotes, L I mostrou o pior comportamento estatístico apesar de não diferir de L IV.

\subsection{2. "Com Secagem Após Condicionamento"}

\subsection{2.a. Grau de Umidade}

Os resultados da determinação do grau de umidade dos lotes de sementes de soja submetidos a secagem, logo após o condicionamento fisiológico, estão expostos na Tabela 9 .

As sementes provenientes da secagem ao ar atingiram valores muito próximos aos dos graus de umidade originais exibidos pela testemunha (Tabela 5); além disso, esses valores foram considerados adequados para o posterior armazenamento por 6 meses, em condições normais de ambiente. 
Tabela 9 - Grau de umidade: valores médios (\%) obtidos para os quatro lotes de sementes de soja submetidos a secagem ao ar após o condicionamento fisiológico. Piracicaba, 1992.

\begin{tabular}{lccccc}
\hline & \multicolumn{5}{c}{ Lotes } \\
\cline { 2 - 6 } Tratamento & L I & L I I & L III & L IV & $\bar{M}$ \\
\hline Testemunha & 10,8 & 10,8 & 10,9 & 11,1 & 10,9 \\
H-12h & 11,7 & 11,8 & 11,6 & 11,7 & 11,7 \\
H-18h & 10,3 & 10,4 & 10,5 & 10,7 & 10,5 \\
H-24h & 10,0 & 10,2 & 10,4 & 10,5 & 10,3 \\
PEG-8atm & 10,9 & 11,0 & 10,8 & 10,9 & 10,9 \\
PEG-6atm & 9,6 & 10,2 & 9,8 & 10,2 & 10,0 \\
\end{tabular}

\subsection{2.b. Qualidade Fisiológica}

As significâncias dos valores de $F$ obtidos nas análises de variancia de todos os parâmetros utilizados para avaliar a qualidade fisiologica das sementes, condicionadas e posteriormente submetidas a secagem, estão representadas na Tabela 10 .

Novamente, como na Tabela 6 , referente a significância do teste $F$ em sementes ainda úmidas após o condicionamento fisiologico, os testes de envelhecimento acelerado e condutividade elétrica detectaram uma maior sensibilidade às causas da variação. 
Tabela 10 - Significâncias do Teste $F$ referentes às determinações para a avaliação do desempenho das sementes de soja submetidas a secagem ao ar logo após o condicionamento fisiológico. Piracicaba, 1992.

\begin{tabular}{lcccc}
\hline & \multicolumn{4}{c}{ Teste } \\
\cline { 2 - 5 } Causas da & Germinação & $\begin{array}{c}\text { Envelhecimento } \\
\text { Acelerado }\end{array}$ & $\begin{array}{c}\text { Condutividade } \\
\text { Elétrica }\end{array}$ & $\begin{array}{c}\text { Emergência } \\
\text { das Plântulas } \\
\text { em Campo }\end{array}$ \\
\hline Lotes & $*$ & $* *$ & $* *$ & NS \\
Tratamentos & NS & $* *$ & $* *$ & NS \\
Lotes x Trat. & NS & $*$ & $*$ & NS \\
\hline
\end{tabular}

NS - não significativo

* - significativo ao nível de $5 \%$ de probabilidade ** - significativo ao nível de $1 \%$ de probabilidade

As médias obtidas nas análises de germinação e envelhecimento acelerado podem ser encontradas na Tabela 11. Os efeitos de tratamento não foram detectados no teste de germinação, havendo apenas diferenças estatísticas entre lotes, onde L I mostrou o pior desempenho e L II o melhor. Os resultados em geral, foram inferiores aos obtidos com as sementes ainda úmidas (Tabela 7), o que confirmou as observações de ARMSTRONG \& MCDONALD (1992), que o osmocondicionamento de sementes de soja seguido de secagem diminui a porcentagem de germinação, já que rompe a integridade das membranas. 
Tabela 11 - Germinação e envel hecimento acelerado: comparação de valores médios de lotes e tratamentos de sementes de soja submetidas a secagem ao ar logo após o condicionamento fisiológico. Piracicaba, 1992.

\begin{tabular}{|c|c|c|c|c|c|c|c|c|c|c|}
\hline \multirow{2}{*}{ Tratamento } & \multicolumn{5}{|c|}{ Germinação (\%) } & \multicolumn{5}{|c|}{ Envel hecimento Acelerado (\%) } \\
\hline & L I & L II & $L I I I$ & L IV & $\overline{\mathrm{M}}$ & L I & L II & $L$ III & L IV & $\bar{M}$ \\
\hline Test. & 95 & 96 & 94 & 96 & $95^{\AA}$ & $85^{\mathrm{ABb}}$ & $95^{\mathrm{Aa}}$ & $91^{\mathrm{Aab}}$ & $93^{\mathrm{Az}}$ & 91 \\
\hline$H-12 h$ & 91 & 90 & 93 & 94 & $92^{A}$ & $81^{B C b}$ & $90^{\mathrm{ABa}}$ & $88^{\mathrm{ABab}}$ & $87^{\mathrm{ABab}}$ & 87 \\
\hline$H-18 h$ & 94 & 95 & 95 & 93 & $94^{A}$ & $73^{\mathrm{Cb}}$ & $82^{\mathrm{Ba}}$ & $82^{\mathrm{Ba}}$ & $84^{\text {Bd }}$ & 80 \\
\hline$H-24 h$ & 92 & 96 & 95 & 94 & $94^{A}$ & $84^{\mathrm{ABa}}$ & $90^{\mathrm{ABa}}$ & $86^{A B a}$ & $85^{\mathrm{Ba}}$ & 86 \\
\hline PEG-8atm & 90 & 97 & 95 & 97 & $95^{h}$ & $82^{B C a}$ & $88^{\mathrm{Ba}}$ & $82^{B a}$ & $87^{\mathrm{ABa}}$ & 85 \\
\hline PEG-6atm & 92 & 98 & 95 & 96 & $95^{\AA}$ & $91^{\mathrm{Aa}}$ & $87^{\mathrm{Bab}}$ & $83^{B b}$ & $90^{\mathrm{ABZ}}$ & 88 \\
\hline Médias & $92^{b}$ & $96^{\mathfrak{a}}$ & $95^{a b}$ & $95^{a b}$ & & 83 & 89 & 86 & 88 & \\
\hline C.V. \% & 6,21 & & & & & 4,90 & & & & \\
\hline
\end{tabular}

Médias seguidas da mesma letra, minúsculas (nas linhas) e maiúsculas (nas colunas), não diferem entre si pelo teste de Tukey, ao nível de $5 \%$ de probabilidade.

No parâmetro envelhecimento acelerado, foi verificado um melhor comportamento da testemunha em todos os lotes, embora sem diferir de alguns tratamentos como $\mathrm{H}-24$ e H-12 h e PEG -6atm. O lote I, como já verificado no teste de envelhecimento acelerado (Tabela 7), condutividade elétrica e emergência das plântulas em campo (Tabela 8), novamente foi estatisticamente inferior em alguns dos tratamentos empregados (testemunha, $\mathrm{H}-12$ e $\mathrm{H}-18 \mathrm{~h}$ ). Nos demais 
tratamentos, essa diferença não foi notada, indicando uma possível tendência de revigoramento dessas sementes quando submetidas a embebição. Valores de $91 \%$ foram alcançados no tratamento PEG -6atm (L I), enquanto a média do mesmo lote foi de apenas $83 \%$.

Comparando esses resultados de envelhecimento acelerado com os do mesmo teste da Tabela 7 , onde as sementes ainda estavam úmidas, pode-se notar que, após a secagem, os tratamentos referentes à hidratação (H) tiveram, em média, seus valores porcentuais diminuídos. Porém, os de condicionamento com solução osmótica apresentaram aumentos, o que pode indicar uma possível vantagem da utilização de produtos químicos nos procedimentos de condicionamento fisiológico. Estes resultados divergem dos relatados por PERL \& FEDER (1980). Esta possível vantagem pode ser analisada sob dois aspectos. Primeiro, como sendo o nível mínimo de umidade em que o reparo fisiológico das membranas possa ocorrer. Segundo, poderia ter sido influenciado pelo maior tempo ( 4 dias) em que as sementes permaneceram em embebição, acima de um teor mínimo de água, período este igualmente recomendado por KHAN et al. $(1980 / 81)$ para sementes em geral, EIRA (1988) para alface, ou ainda, por DONI FILHO (1992) para feijão.

Os resultados de condutividade elétrica (Tabela 12) indicaram uma interação significativa entre lotes e tratamentos, mesmo após a secagem. De um modo geral, todos 
os tratamentos superaram a testemunha, havendo um melhor desempenho das sementes que alcançaram maiores teores de água durante o condicionamento, ou seja, H-24 h, PEG -8 atm e PEG -6 atm. Essa mesma tendência foi anteriormente notada nos dados da Tabela 8. A secagem posterior determinou maior perda de eletrólitos, em todas as combinações, fato facilmente entendido pela aceitação da teoria da conformação hexagonal proposta por LUZZATI \& HUSSON (1962) e SIMON (1984), admitindo que sementes secas possuem membranas desorganizadas, o que facilita a lixiviação dos solutos nos primeiros momentos da embebição. ARMSTRONG \& MCDONALD (1992), também relataram aumentos na condutividade elétrica em sementes de soja condicionadas com PEG e posteriormente secas. A testemunha que não sofreu nenhuma embebição, apresentou os valores mais elevados, o que revela que o efeito da hidratação sobre as membranas é benéfico quando avaliado sob esse parâmetro, e permanece após a secagem, apesar da existência de reversão.

Quanto aos lotes, novamente foi verificada uma uniformização da qualidade, só ocorrendo diferenças na testemunha, sendo L I o de pior comportamento e L II o me 1 hor.

os valores de emergência das plântulas em campo (Tabela 12) não detectaram efeitos de tratamentos e lotes, mostrando apenas uma pequena queda nas porcentagens em geral, quando comparadas com os resultados do mesmo teste da Tabela 8 , indicando que a secagem não diminuiu totalmente possíveis efeitos do condicionamento. 
Tabela 12 - Condutividade elétrica e emergência das plântulas em campo: comparação de valores médios de lotes e tratamentos de sementes de soja submetidas a secagem ao ar logo após o condicionamento fisiológico. Piracicaba, 1992.

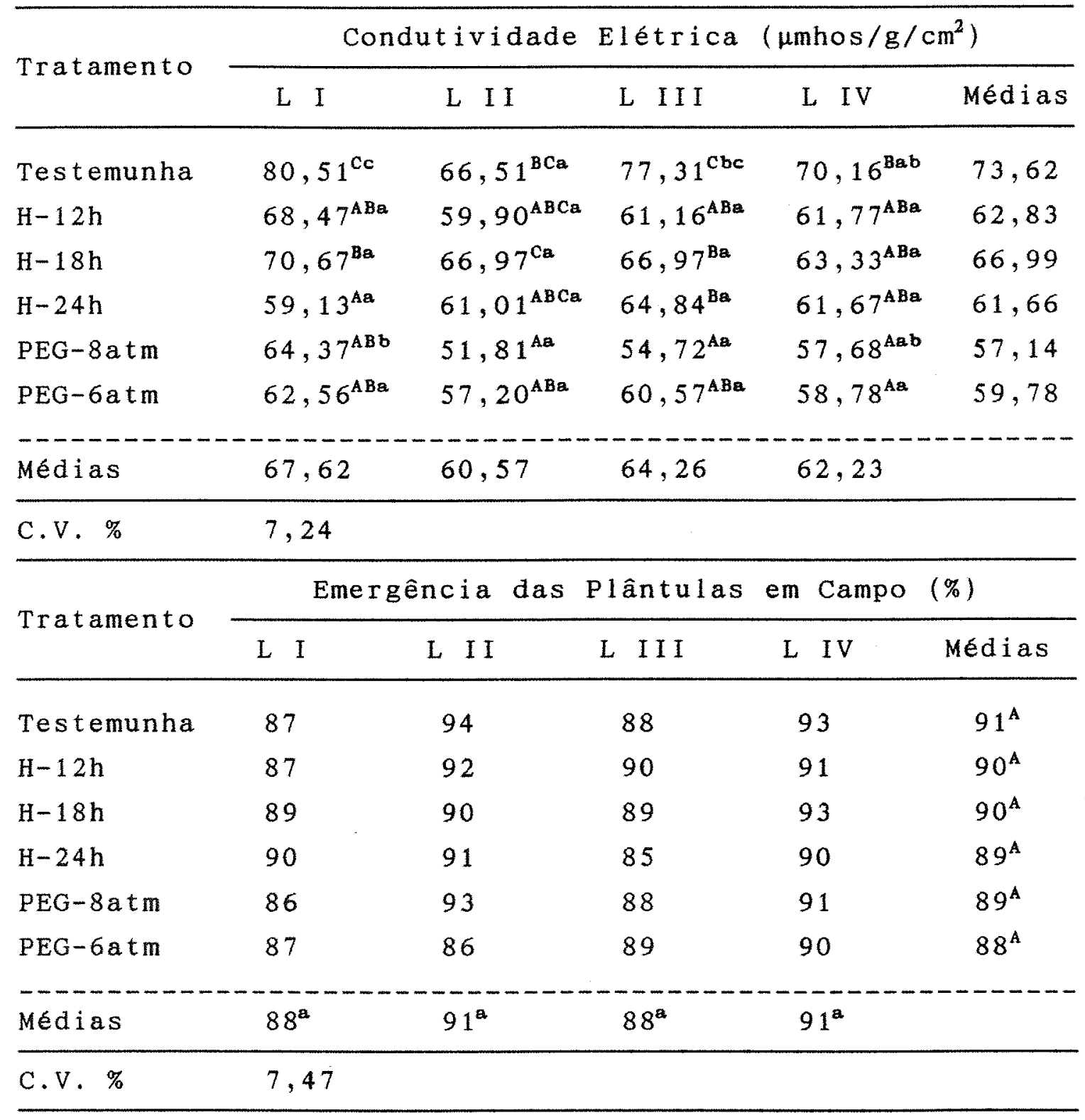

Médias seguidas da mesma letra, minúsculas (nas linhas) e maísculas (nas colunas), não diferem entre si pelo teste de Tukey, ao nível de $5 \%$ de probabilidade. 
4.2. Epoca II

\subsubsection{Sementes Condicionadas e Armazenadas por Três Meses}

4.2.1.a. Grau de Umidade

Os resultados do grau de umidade das sementes após três meses de armazenamento, estão contidos na Tabela 13

Tabela 13 - Grau de umidade: valores médios (\%) obtidos para os quatro lotes de sementes de soja condicionadas por três meses. Piracicaba, 1992 .

\begin{tabular}{lccccc}
\hline & \multicolumn{5}{c}{ Lotes } \\
\cline { 2 - 6 } Tratamento & L I & L I I & L II I & L IV & $\bar{M}$ \\
\hline Testemunha & 10,6 & 10,5 & 10,3 & 10,6 & 10,5 \\
H-12h & 10,7 & 10,6 & 10,4 & 10,4 & 10,5 \\
H-18h & 10,4 & 10,4 & 10,5 & 10,6 & 10,5 \\
H-24h & 10,4 & 10,4 & 10,3 & 10,4 & 10,4 \\
PEG-8atm & 10,5 & 10,6 & 10,4 & 10,6 & 10,5 \\
PEG-6atm & 10,6 & 10,6 & 10,5 & 10,6 & 10,6 \\
\hline
\end{tabular}


Nesta segunda época experimental, os valores obtidos variaram principalmente com as condições ambiente do laboratório de análise de sementes, nos momentos em que foram feitas as suas determinações mas, em geral, apresentaram decréscimos em relação aos teores de água das sementes submetidas a secagem (Tabela 9) após os tratamentos.

\subsection{1.b. Qualidade Fisiologica}

A Tabela 14 apresenta as significâncias dos valores de $F$ obtidos nas análises da variancia dos quatro testes empregados em sementes de soja, condicionadas e armazenadas por 3 meses, com o objetivo de avaliar a qualidade fisiológica.

Na Tabela 15 pode-se observar a comparaça das médias de germinação e envelhecimento acelerado. Os valores de germinação praticamente não exibiram diferenças estatísticas entre si, havendo apenas um desempenho inferior da interação $\mathrm{H}-18$ h ( $\mathrm{L}$ IV). Quando comparados com a Tabela 11, referente ao teste de germinação de sementes condicionadas e posteriormente secas, os valores das sementes armazenadas por 3 meses, foram em geral inferiores, apesar da queda não ter sido acentuada. Os resultados de envelhecimento acelerado da Tabela 15 , indicam diferenças estatísticas entre todos os tratamentos de L I e os de L III. H-12 h (L I) revelou-se inferior aos demais, apesar de não 
diferir de PEG-8atm (L I). No lote III, o tratamento H-12 h apresentou o pior desempenho, não diferindo porém de PEG - 8 atm e PEG - 6atm. Novamente todos os valores manifestaram queda quando comparados com a Tabela (11b), referentes ao envelhecimento acelerado das sementes condicionadas e posteriormente secas.

Tabela 14 - Significancias do Teste $F$ referentes às determinações para a avaliação do desempenho de sementes de soja submetidas ao condicionamento fisiológico, secas ao ar e posteriormente armazenadas por três meses. Piracicaba, 1992.

\begin{tabular}{lcccc}
\hline & \multicolumn{4}{c}{ Teste } \\
\cline { 2 - 5 } Causas da & Germinação & $\begin{array}{c}\text { Envelhecimento } \\
\text { Acelerado }\end{array}$ & $\begin{array}{c}\text { Condutividade } \\
\text { Elétrica }\end{array}$ & $\begin{array}{c}\text { Emergência } \\
\text { das Plântulas } \\
\text { em Campo }\end{array}$ \\
\hline Lotes & $*$ & $* *$ & $* *$ & $*$ \\
Tratamentos & $*$ & $* *$ & $* *$ & NS \\
Lotes x Trat. & $* *$ & $*$ & $*$ & NS \\
\hline
\end{tabular}

NS - não significativo

* - significativo ao nível de $5 \%$ de probabilidade ** - significativo ao nivel de $1 \%$ de probabilidade 
Os valores de envelhecimento acelerado (Tabela 15) foram, em sua maioria, inferiores aos de germinação (Tabela 15), indicando possíveis diferenças de vigor devido a lotes e tratamentos. Passados três meses de armazenamento, todos os tratamentos empregados em lotes de vigor mais alto (L II e IV), mantiveram elevadas porcentagens; nos lotes I e III, alguns tratamentos não proporcionaram efeitos benéficos (H-12 h e PEG -8atm). KNYPL \& KHAN (1981) também admitiram que sementes condicionadas e armazenadas por períodos prolongados, exibiram desempenho progressivamente deficiente com o passar do tempo, apesar de não relacionarem este fato com o vigor das sementes. Em contrapartida, BROCKLEHURST et al. (1987), trabalhando com lotes comerciais de cebola, condicionadas em papel de filtro umedecidos com PEG 6000 a $15^{\circ} \mathrm{C}$ por 14 dias, em presença de 1 uz, e posteriormente secas e armazenadas, obtiveram bons resultados após 12 meses, a $10^{\circ} \mathrm{C}$ e $9 \%$ de umidade, o que os fez admitir, que o "priming" pode adiar o início da deterioração em sementes. Segundo os mesmos autores, de acordo com a técnica de condicionamento empregada, os cuidados durante a secagem e as condições de armazenamento utilizadas, pode-se determinar a manutenção ou não dos benefícios obtidos através do tratamento condicionador. 
Tabela 15 - Germinação e envelhecimento acelerado: comparação de valores médios de lotes e tratamentos de sementes de soja armazenadas por três meses após - condicionamento fisiológico e a secagem. Piracicaba, 1992 .

\begin{tabular}{|c|c|c|c|c|c|c|c|c|c|c|}
\hline \multirow{2}{*}{ Tratamento } & \multicolumn{5}{|c|}{ Germinação (\%) } & \multicolumn{5}{|c|}{ Envelhecimento Acelerado (\%) } \\
\hline & L I & L II & L III & L IV & $\overline{\mathrm{M}}$ & L I & L II & L III & L IV & $\bar{M}$ \\
\hline Test. & $89^{\mathrm{ABab}}$ & $88^{\mathrm{Ab}}$ & $93^{\text {kab }}$ & $95^{\mathrm{A} a b}$ & 91 & $83^{h a}$ & $90^{\mathrm{Az}}$ & $83^{\text {ha }}$ & $84^{\mathrm{Az}}$ & 85 \\
\hline $\mathrm{H}-12 \mathrm{~h}$ & $90^{\mathrm{ABa}}$ & $88^{d a}$ & $94^{\mathrm{ha}}$ & $89^{\mathrm{ABz}}$ & 90 & $59^{C b}$ & $82^{\mathrm{Az}}$ & $69^{\mathrm{Bb}}$ & $80^{\mathrm{Aa}}$ & 72 \\
\hline$H-18 h$ & $92^{\AA a}$ & $88^{\mathrm{Aa}}$ & $91^{\mathrm{tz}}$ & $80^{\mathrm{cb}}$ & 88 & $73^{\mathrm{ABb}}$ & $85^{\mathrm{ha}}$ & $82^{\mathrm{hab}}$ & $83^{\mathrm{Aa}}$ & 81 \\
\hline $\mathrm{H}-24 \mathrm{~h}$ & $91^{\mathrm{ABa}}$ & $90^{18}$ & $90^{\mathrm{Aa}}$ & $89^{\mathrm{ABa}}$ & 90 & $80^{48}$ & $86^{\mathrm{Aa}}$ & $83^{\mathrm{AA}}$ & $85^{\mathrm{Aa}}$ & 83 \\
\hline PEG-8atm & $84^{\mathrm{Bb}}$ & $87^{\mathrm{Aab}}$ & $92^{\mathrm{Aa}}$ & $90^{\mathrm{ABab}}$ & 88 & $64^{\mathrm{BCb}}$ & $85^{\mathrm{ha}}$ & $80^{\mathrm{ABa}}$ & $85^{\mathrm{Aa}}$ & 79 \\
\hline PEG-6atm & $90^{\mathrm{ABa}}$ & $90^{12}$ & $89^{\text {Aa }}$ & $88^{\mathrm{Bz}}$ & 89 & $73^{\mathrm{ABC}}$ & $85^{\mathrm{Aab}}$ & $76^{\mathrm{ABbc}}$ & $87^{\mathrm{Aa}}$ & 81 \\
\hline Médias & 89 & 88 & 91 & 89 & & 72 & 86 & 79 & 84 & \\
\hline C.V. \% & 4,46 & & & & & 6,05 & & & & \\
\hline
\end{tabular}

Médias seguidas da mesma letra, minúsculas (nas linhas) e maiúsculas (nas colunas), não diferem entre si pelo teste de Tukey, ao nível de $5 \%$ de probabilidade.

Os resultados dos testes de condutividade elétrica e emergência das plântulas em campo estão contidos na Tabela 16. No teste de condutividade elétrica, o melhor desempenho quanto a tratamentos foi obtido por PEG -6atm, independente do lote empregado, apesar de não divergir da interação PEG $-8 \mathrm{~atm}$ com L II, III e IV. o lote II foi estatisticamente superior aos demais, não diferindo de L IV e L III, em alguns tratamentos. Novamente, como já observado 
nas Tabelas 8 e 12 de condutividade elétrica, os melhores tratamentos foram os que empregaram produto químico. Após três meses de armazenamento, dois grupos distintos quanto ao vigor puderam ser notados: um inferior, referente à testemunha, $\mathrm{H}-12$ e $\mathrm{H}-18$ h e outro, com elevado vigor, incluindo $\mathrm{H}-24 \mathrm{~h}$, PEG $-8 \mathrm{~atm}$ e PEG -6atm.

De um modo geral, houve apenas um pequeno acréscimo em todos resultados do teste de condutividade elétrica após 3 meses de armazenamento, quando comparado com a Tabela 12, referente ao mesmo teste, onde as sementes foram condicionadas e, posteriormente secas em ambiente natural. Os melhores tratamentos tiveram os mínimos acréscimos, o que pode indicar um possivel reparo celular.

Os lotes apresentaram diferenças de qualidade em todos os tratamentos, discordando do que ocorreu nas Tabelas 8 e 12 do mesmo teste de condutividade. Este fato pode revelar um possivel ponto critico, onde a partir do qual, tem início o processo de deterioração, independentemente da técnica de condicionamento empregada. Apenas o lote II, de alto vigor, manteve-se superior aos demais, para todos os tratamentos empregados. 
Tabela 16 - Condutividade elétrica e emergência das plântulas em campo: comparação de valores médios de lotes e tratamentos de sementes de soja armazenadas por três meses após o condicionamento fisiológico e a secagem. Piracicaba, 1992 .

\begin{tabular}{|c|c|c|c|c|c|}
\hline \multirow{2}{*}{ Tratamento } & \multicolumn{5}{|c|}{ Condutividade Elétrica ( $\mu$ mhos $/ \mathrm{g} / \mathrm{cm})$} \\
\hline & L I & L I I & L I I I & L IV & Médias \\
\hline Test emunha & $80,33^{\mathrm{cb}}$ & $71,35^{\mathrm{Da}}$ & $80,38^{\mathrm{cb}}$ & $73,96^{8 \mathbf{a}}$ & 76,50 \\
\hline $\mathrm{H}-12 \mathrm{~h}$ & $82,57^{\mathrm{cb}}$ & $73,08^{\mathrm{Da}}$ & $77,04^{\mathrm{Cab}}$ & $72,42^{\mathrm{Ba}}$ & 76,28 \\
\hline $\mathrm{H}-18 \mathrm{~h}$ & $81,66^{\mathrm{cc}}$ & $67,84^{\mathrm{CDa}}$ & $69,11^{\mathrm{Bab}}$ & $74,49^{\mathrm{Bb}}$ & 73,27 \\
\hline$H-24 h$ & $71,67^{\mathrm{Bb}}$ & $63,32^{\mathrm{BCa}}$ & $66,54^{\mathrm{Bab}}$ & $70,36^{\mathrm{Bb}}$ & 67,97 \\
\hline PEG-8atm & $70,26^{\mathrm{Bb}}$ & $59,56^{\mathrm{ABa}}$ & $64,27^{\mathrm{ABab}}$ & $62,25^{\mathrm{Aa}}$ & 64,09 \\
\hline PEG-6atm & $62,81^{\mathrm{Ab}}$ & $53,95^{\mathrm{Aa}}$ & $58,61^{\mathrm{Aab}}$ & $58,97^{\mathrm{Aab}}$ & 58,59 \\
\hline \multicolumn{6}{|c|}{ Médias $\quad 74,88 \quad 64,85 \quad 69,33 \quad 68,74$} \\
\hline C.V. $\%$ & 4,78 & & & & \\
\hline \multirow{2}{*}{ Tratamento } & \multicolumn{2}{|c|}{ Emergência das } & Plântulas & \multirow{2}{*}{ em campo } & $(\%)$ \\
\hline & L I & L I I & $L$ I I I & & Médias \\
\hline Testemunha & 73 & 71 & 77 & 77 & $75^{A}$ \\
\hline $\mathrm{H}-12 \mathrm{~h}$ & 66 & 77 & 73 & 67 & $71^{A}$ \\
\hline$H-18 h$ & 60 & 81 & 64 & 76 & $70^{\mathrm{A}}$ \\
\hline $\mathrm{H}-24 \mathrm{~h}$ & 63 & 83 & 75 & 73 & $74^{A}$ \\
\hline PEG-8atm & 53 & 68 & 63 & 67 & $63^{A}$ \\
\hline PEG-6atm & 66 & 69 & 68 & 70 & $68^{A}$ \\
\hline Médias & $64^{b}$ & $75^{\mathrm{a}}$ & $70^{\mathrm{ab}}$ & $72^{\mathrm{ab}}$ & \\
\hline C.V. \% & 13,62 & & & & \\
\hline
\end{tabular}

Médias seguidas da mesma letra, minúsculas (nas linhas) e maiúsculas (nas colunas), não diferem entre si pelo teste de Tukey, ao nível de $5 \%$ de probabilidade. 
86.

Os resultados de emergência das plântulas em campo (Tabela 16), não diferiram quanto ao efeito de tratamentos; em geral, houve uma grande perda na porcentagem de emergência, quando comparada com as Tabelas 8 e 12 do mesmo teste, provavelmente devido a condições ambiente desfavoráveis, ou mesmo início da deterioração das sementes. o lote II, manteve-se superior aos demais, não divergindo porém, de L III e L IV; os maiores valores médios foram alcançados pelos tratamentos $\mathrm{H}-18$ e $\mathrm{H}-24 \mathrm{~h}$ dentro de L II, indicando, possivelmente, um estado crítico de deterioracão dos demais lotes, onde o condicionamento não pôde mais manter ou mesmo restaurar a viabilidade.

\section{3. Época II I}

4.3.1. Sementes Condicionadas e Armazenadas por Seis Meses

\subsection{1.a. Grau de Umidade}

A Tabela 17 contém os resultados do grau de umidade das sementes condicionadas e armazenadas por seis meses. 
Tabela 17 - Grau de umidade: valores médios (\%) obtidos para os quatro lotes de sementes de soja condicionadas e armazenadas por seis meses. Piracicaba, 1993.

\begin{tabular}{lccccc}
\hline \multirow{2}{*}{ Tratamento } & \multicolumn{5}{c}{ Lotes } \\
\cline { 2 - 6 } & L I & L I I & L I I I & L IV & $\bar{M}$ \\
\hline Testemunha & 12,2 & 11,7 & 12,6 & 12,0 & 12,1 \\
H-12h & 12,4 & 12,4 & 11,1 & 11,9 & 12,0 \\
H-18h & 11,9 & 12,1 & 11,6 & 11,7 & 11,8 \\
H-24h & 12,1 & 11,9 & 12,2 & 11,3 & 11,9 \\
PEG-8atm & 11,4 & 11,5 & 12,1 & 12,0 & 11,8 \\
PEG-6atm & 12,0 & 12,0 & 10,6 & 11,6 & 11,6 \\
\hline
\end{tabular}

Os resultados referentes ao grau de umidade da Tabela 17, foram obtidos de acordo com as condições ambiente do laboratório de análise de semente no momento das determinações. Houve um pequeno acréscimo no teor de água das sementes, em geral, quando comparadas com os do mesmo teste, exibidos nas Tabelas 9 e 13 .

\subsection{1.b. Qualidade Fisiologica}

A Tabela 18 mostra os resultados da análise da variância, representados pela significância do teste $F$ das variáveis utilizadas, a fim de avaliar a qualidade fisiologica das sementes armazenadas por seis meses, após o condicionamento fisiológico e secagem. 
Tabela 18 - Significâncias do Teste $F$ referentes às determinações para a avaliação do desempenho de sementes de soja submetidas ao condicionamento fisiológico, secas ao ar e posteriormente armazenadas por seis meses. Piracicaba, 1993.

\begin{tabular}{lcccc}
\hline & \multicolumn{4}{c}{ Teste } \\
\cline { 2 - 5 } Causas da & Germinação & $\begin{array}{c}\text { Envelhecimento } \\
\text { Acelerado }\end{array}$ & $\begin{array}{c}\text { Condutividade } \\
\text { Elétrica }\end{array}$ & $\begin{array}{c}\text { Emergência } \\
\text { das Plântulas } \\
\text { em Campo }\end{array}$ \\
\hline Lotes & $*$ & $* *$ & $* *$ & $*$ \\
Tratamentos & NS & $* *$ & $* *$ & NS \\
Lotes x Trat. & NS & $* *$ & $* *$ & NS \\
\hline
\end{tabular}

NS - não significativo

* - significativo ao nível de $5 \%$ de probabilidade ** - significativo ao nível de $1 \%$ de probabilidade

A Tabela 19 contém os resultados dos parâmetros germinação e envelhecimento acelerado. Os valores do teste de germinação não diferiram da testemunha e apresentaram valores elevados, levando-se em consideração que as sementes estiveram armazenadas por 6 meses em condição ambiente. Quanto aos lotes, L II mostrou-se superior aos demais, apesar de não diferir de L III.

Foi notada queda gradativa da qualidade com o armazenamento, através da observação dos resultados de envelhecimento acelerado da Tabela 19 comparada com as Tabelas 7 e 11. Em geral, todos os tratamentos foram 
inferiores a testemunha, com exceção de H-18 e H-24 h (L II) e H-24, PEG $-8 \mathrm{~atm}$ e $-6 \mathrm{~atm}$ (L IV), o que pode sugerir novamente que a manutenção da viabilidade somente pode ser possível em lotes que não atingiram um ponto crítico de deterioração, além de indicar uma eventual superioridade do tratamento H-24 h em relação aos demais.

o teste de condutividade elétrica (Tabela 20) revelou diferenças entre os tratamentos; comparados à testemunha, notou-se a existência de dois grupos, um relativo a PEG-6 e PEG -8atm e superior aos demais (testemunha, H-12, H-18 e H-24 h). Quanto aos lotes, L II mostrou o melhor desempenho, independente do tratamento empregado. A interação PEG - 6atm (L II) superou todas as outras, sugerindo que a resposta ao condicionamento depende não só do tratamento, mas principalmente da qualidade inicial do lote empregado.

A Tabela 20 de emergencia das plântulas em campo não mostrou diferenças entre os tratamentos. Houve em sua totalidade uma queda significativa de valores após 6 meses de armazenamento, quando comparados com a Tabela 12 , o que sugere a não existência de benefícios relativos ao condicionamento fisiologico. O lote II manteve-se superior estatisticamente aos demais, apesar de não divergir de L III e L IV. 
Tabela 19 - Germinação e envelhecimento acelerado: comparação de valores médios de lotes e tratamentos de sementes de soja armazenadas por seis meses após o condicionamento fisiologico e secagem. Piracicaba, 1993.

\begin{tabular}{|c|c|c|c|c|c|c|c|c|c|c|}
\hline \multirow{2}{*}{ Tratamento } & \multicolumn{5}{|c|}{ Germinação (\%) } & \multicolumn{5}{|c|}{ Envelhecimento Acelerado (\%) } \\
\hline & L I & L II & L III & L IV & $\bar{M}$ & L I & L II & L III & L IV & $\overline{\mathrm{M}}$ \\
\hline Test. & 93 & 92 & 94 & 93 & $93^{d}$ & $71^{\mathrm{Aa}}$ & $80^{\mathrm{Al}}$ & $76^{\mathrm{Aa}}$ & $70^{\mathrm{ABa}}$ & 75 \\
\hline $\mathrm{H}-12 \mathrm{~h}$ & 93 & 97 & 93 & 94 & $94^{A}$ & $24^{\mathrm{Db}}$ & $38^{\mathrm{Ca}}$ & $45^{\mathrm{Ba}}$ & $41^{\mathrm{Cs}}$ & 37 \\
\hline $\mathrm{H}-18 \mathrm{~h}$ & 93 & 97 & 93 & 92 & $94^{A}$ & $49^{\mathrm{BCb}}$ & $74^{\mathrm{kg}}$ & $49^{\mathrm{Bb}}$ & $58^{\mathrm{Bb}}$ & 58 \\
\hline$H-24 h$ & 91 & 95 & 91 & 94 & $93^{A}$ & $54^{\mathrm{BC}}$ & $71^{\mathrm{ABab}}$ & $59^{\mathrm{Bbc}}$ & $73^{A 8}$ & 64 \\
\hline PEG-8atm & 92 & 94 & 94 & 94 & $94^{h}$ & $44^{\mathrm{BCC}}$ & $60^{\mathrm{Bab}}$ & $51^{\mathrm{Bbc}}$ & $67^{\mathrm{ABa}}$ & 55 \\
\hline PEG-6atm & 91 & 93 & 93 & 84 & $90^{A}$ & $39^{\mathrm{Cc}}$ & $58^{\mathrm{Bab}}$ & $45^{\mathrm{Bbc}}$ & $64^{\mathrm{ABa}}$ & 52 \\
\hline Médias & $92^{b}$ & $95^{\mathfrak{Z}}$ & $93^{a b}$ & $92^{b}$ & & 47 & 64 & 55 & 62 & \\
\hline C.V. \% & 5,1 & & & & & 8,14 & & & & \\
\hline
\end{tabular}

Médias seguidas da mesma letra, minúsculas (nas linhas) e maiúsculas (nas colunas), não diferem entre si pelo teste de Tukey, ao nível de $5 \%$ de probabilidade.

Em resumo, apesar da manutenção da estrutura das membranas em $\mathrm{H}-24$ h e PEG, esta não foi suficiente para justificar o uso do condicionamento fisiológico, pois o desempenho geral não foi beneficiado. 
Tabela 20 - Condutividade eletrica e emergência das plântulas em campo: comparação de valores médios de lotes e tratamentos de sementes de soja armazenadas por seis meses após o condicionamento fisiológico e a secagem. Piracicaba, 1993.

\begin{tabular}{|c|c|c|c|c|c|}
\hline \multirow{2}{*}{ Tratamento } & \multicolumn{5}{|c|}{ Condutividade Elétrica $(\mu \mathrm{mhos} / \mathrm{g} / \mathrm{cm})$} \\
\hline & L I & L I I & L I I I & L IV & Médias \\
\hline Testemunha & $88,49^{\mathrm{Db}}$ & $76,57^{\mathrm{ca}}$ & $74,15^{\mathrm{Ba}}$ & $72,34^{\mathrm{BCa}}$ & 77,89 \\
\hline $\mathrm{H}-12 \mathrm{~h}$ & $86,06^{\mathrm{CDC}}$ & $75,25^{\mathrm{BCa}}$ & $78,96^{\mathrm{BCab}}$ & $81,83^{D b c}$ & 80,53 \\
\hline$H-18 h$ & $84,84^{\mathrm{cDb}}$ & $71,85^{\mathrm{BCa}}$ & $79,87^{\mathrm{BCb}}$ & $73,28^{\mathrm{BCa}}$ & 77,46 \\
\hline$H-24 h$ & $80,01^{\mathrm{BCbc}}$ & $73,17^{\mathrm{BCa}}$ & $82,67^{\mathrm{cc}}$ & $75,92^{\mathrm{CDab}}$ & 77,94 \\
\hline PEG-8atm & $75,61^{\mathrm{Bb}}$ & $68,77^{\mathrm{Ba}}$ & $65,31^{\mathrm{Aa}}$ & $67,46^{\mathrm{ABa}}$ & 69,29 \\
\hline PEG-6atm & $68,36^{\mathrm{Ab}}$ & $58,00^{\mathrm{Aa}}$ & $66,84^{\mathrm{Ab}}$ & $64,19^{\mathrm{Aab}}$ & 64,35 \\
\hline Médias & 80,56 & 70,60 & 74,64 & 72,50 & ----1 \\
\hline C.V. $\%$ & 4,57 & & & & \\
\hline \multirow{2}{*}{ Tratamento } & \multicolumn{5}{|c|}{ Emergência das Plântulas em campo(\%) } \\
\hline & L I & L I I & L I I I & L IV & Médias \\
\hline Testemunha & 71 & 75 & 75 & 69 & $73^{\mathrm{A}}$ \\
\hline$H-12 h$ & 58 & 67 & 64 & 65 & $63^{\mathrm{A}}$ \\
\hline $\mathrm{H}-18 \mathrm{~h}$ & 68 & 73 & 57 & 73 & $68^{\mathrm{A}}$ \\
\hline $\mathrm{H}-24 \mathrm{~h}$ & 58 & 72 & 69 & 63 & $66^{\mathrm{A}}$ \\
\hline PEG-8atm & 58 & 76 & 71 & 76 & $70^{\mathbf{A}}$ \\
\hline PEG-6atm & 62 & 73 & 70 & 60 & $66^{\mathrm{A}}$ \\
\hline Médias & $63^{b}$ & $73^{a}$ & $68^{\mathrm{ab}}$ & $68^{a b}$ & \\
\hline C.V. \% & 12,18 & & & & \\
\hline
\end{tabular}

Médias seguidas da mesma letra, minúsculas (nas linhas) e maiúsculas (nas colunas), não diferem entre si pelo teste de Tukey, ao nível de $5 \%$ de probabilidade. 


\subsection{Composição Química}

Os resultados da análise de variância, representados pela significância do teste $F$ das variáveis empregadas para avaliar a composição química das sementes durante todo o experimento (desde o condicionamento até 6 meses de armazenamento), estão exibidos na Tabela 21 .

Tabela 21 - Significâncias do Teste $F$ referentes às determinações para a avaliação da composição química das sementes durante o experimento. Piracicaba, $1992 / 93$.

\begin{tabular}{lcccccc}
\hline \multirow{2}{*}{ Causas da } & $\begin{array}{c}\text { Teor de } \\
\text { Oleo }\end{array}$ & $\begin{array}{c}\text { fndice de } \\
\text { Acidez }\end{array}$ & $\begin{array}{c}\text { fndice de } \\
\text { Peróxido }\end{array}$ & $\begin{array}{c}\text { Proteína } \\
\text { Bruta }\end{array}$ & $\begin{array}{c}\text { Açúcares } \\
\text { Totais }\end{array}$ & $\begin{array}{c}\text { Açúcares } \\
\text { Redutores }\end{array}$ \\
\hline Lotes & $* *$ & NS & NS & NS & NS & NS \\
Tratamentos & $* *$ & $* *$ & $* *$ & $* *$ & $*$ & NS \\
Epocas & $* *$ & $* *$ & $* *$ & $* *$ & $* *$ & $*$ \\
L X T & NS & NS & NS & NS & NS & NS \\
L X E & $* *$ & NS & NS & NS & NS & NS \\
T X E & $* *$ & $* *$ & $* *$ & $* *$ & $* *$ & $*$ \\
\hline
\end{tabular}

NS - não significativo

* - significativo ao nível de $5 \%$ de probabilidade ** - significativo ao nível de $1 \%$ de probabilidade 
93.

4.4.1. Teor de 61 eo

Através da Tabela 22 , valores médios do teor de óleo das sementes entre lotes, tratamentos e épocas podem ser comparados após o condicionamento fisiológico.

$$
\text { Entre tratamentos, } \mathrm{H}-24 \text { h superou }
$$

estatisticamente $\mathrm{H}-18, \mathrm{H}-12 \mathrm{~h}$ e a testemunha, apesar de não diferir de PEG $-8 a \mathrm{tm}$ e PEG -6atm. Os lotes I e III apresentaram melhor desempenho que os lotes II e IV; e entre épocas, 6 meses foi superior às demais.

Porém, apesar da análise estatística ter acusado as diferenças apontadas acima, não existe significado prático algum. 
94.

Tabela 22 - Teor de óleo (\% m.s.): comparação de valores médios de lotes, tratamentos e épocas de sementes de soja condicionadas fisiologicamente, posteriormente secas em ambiente natural e finalmente armazenadas por 6 meses. Piracicaba, $1992 / 93$.

\begin{tabular}{|c|c|c|c|c|c|}
\hline \multirow{2}{*}{ Tratamento } & \multicolumn{5}{|c|}{ Lotes } \\
\hline & L I & L I I & L I I I & L. IV & Médias \\
\hline Testemunha & 21,259 & 21,066 & 21,247 & 21,068 & $21,160^{D}$ \\
\hline$H-12 h$ & 21,464 & 21,235 & 21,617 & 21,178 & $21,373^{c}$ \\
\hline$H-18 h$ & 21,588 & 21,486 & 21,589 & 21,225 & $21,472^{\mathrm{BC}}$ \\
\hline$H-24 h$ & 21,843 & 21,625 & 21,816 & 21,630 & $21,728^{A}$ \\
\hline $\mathrm{PEG}-8 \mathrm{~atm}$ & 21,595 & 21,387 & 22,010 & 21,459 & $21,612^{\mathrm{AB}}$ \\
\hline PEG-6atm & 21,787 & 21,450 & 21,744 & 21,466 & $21,611^{A B}$ \\
\hline \multirow{2}{*}{\multicolumn{6}{|c|}{ 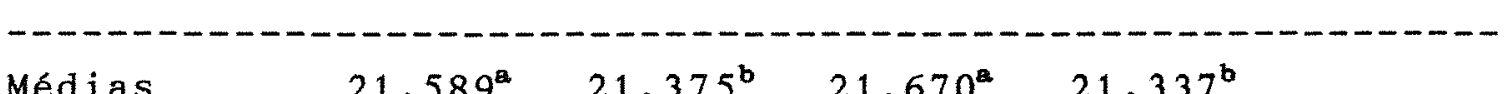 }} \\
\hline & & & & & \\
\hline C.V. \% & \multicolumn{5}{|l|}{0,427} \\
\hline \multirow{2}{*}{ Tratamento } & \multicolumn{5}{|c|}{ Epocas } \\
\hline & Sem secagem & Com secagem & 3 meses & 6 meses & Médias \\
\hline Testemunha & $20,688^{\mathrm{cc}}$ & $20,980^{B b c}$ & $21,727^{\mathrm{Aa}}$ & $21,250^{\mathrm{cb}}$ & 21,160 \\
\hline$H-12 h$ & $21,166^{\mathrm{Bb}}$ & $21,292^{\mathrm{Bb}}$ & $21,190^{B b}$ & $21,848^{\mathrm{Ba}}$ & 21,373 \\
\hline$H-18 h$ & $21,542^{\text {Aab }}$ & $21,246^{\mathrm{Bb}}$ & $21,262^{\mathrm{Bb}}$ & $21,839^{\mathrm{Ba}}$ & 21,472 \\
\hline$H-24 h$ & $21,161^{\mathrm{Bb}}$ & $22,060^{A a}$ & $21,353^{\mathrm{Bb}}$ & $22,348^{\mathrm{Aa}}$ & 21,728 \\
\hline $\mathrm{PEG}-8 \mathrm{~atm}$ & $21,319^{\mathrm{ABb}}$ & $21,982^{A a}$ & $21,037^{\mathrm{Bb}}$ & $22,118^{\mathrm{ABa}}$ & 21,612 \\
\hline $\mathrm{PEG}-6 \mathrm{~atm}$ & $21,332^{\mathrm{ABb}}$ & $21,820^{\mathrm{AB}}$ & $21,232^{\mathrm{Bb}}$ & $22,065^{\mathrm{ABa}}$ & 21,611 \\
\hline Médias & 21,201 & 21,562 & 21,300 & 21,911 & \\
\hline
\end{tabular}


Tabela 22 - Teor de óleo (\% m.s.): comparação de valores médios de lotes, tratamentos e épocas de sementes de soja condicionadas fisiologicamente, posteriormente secas em ambiente natural e finalmente armazenadas por 6 meses. Piracicaba, 1992/93. Continuação.

\begin{tabular}{lccccc}
\hline & \multicolumn{5}{c}{ Epocas } \\
\cline { 2 - 6 } Tratamento & Sem secagem & Com secagem & 3 meses & 6 meses & Médias \\
\cline { 2 - 6 } L I & $21,328^{\mathrm{Ac}}$ & $21,676^{\mathrm{ABb}}$ & $21,437^{\mathrm{Abc}}$ & $21,918^{\mathrm{Ba}}$ & 21,589 \\
L I I & $21,233^{\mathrm{Ab}}$ & $21,537^{\mathrm{ABa}}$ & $21,138^{\mathrm{Bb}}$ & $21,592^{\mathrm{Ca}}$ & 21,375 \\
L I I I & $21,375^{\mathrm{Ac}}$ & $21,639^{\mathrm{ABb}}$ & $21,407^{\mathrm{Abc}}$ & $22,262^{\mathrm{Aa}}$ & 21,670 \\
L IV & $20,869^{\mathrm{Bc}}$ & $21,395^{\mathrm{Bb}}$ & $21,218^{\mathrm{ABb}}$ & $21,872^{\mathrm{Ba}}$ & 21,337 \\
- Médias & 21,201 & $21,562^{-}$ & 21,300 & 21,911 & \\
\hline C.V. \% & 0,427 & & & & \\
\hline
\end{tabular}

Médias seguidas da mesma letra, minúsculas (nas linhas) e maiúsculas (nas colunas), não diferem entre si pelo teste de Tukey, ao nível de $5 \%$ de probabilidade.

4.4.2. Indice de Acidez

Os resultados do indice de acidez da Tabela 23, indicaram que não houve variação entre lotes, apenas um aumento entre épocas. Entre tratamentos, PEG-8atm e PEG -6atm foram os piores e a testemunha, a melhor estatisticamente, apesar de não divergir de $\mathrm{H}-12 \mathrm{~h}$. 
Os tratamentos com produto químico que atingiram os maiores teores de água durante o condicionamento, também apresentaram os maiores indices de acidez, sugerindo um aumento da pressão de hidrólise dos triglicerídeos.

\subsection{3. fndice de Peróxido}

A comparação dos valores médios do índice de peróxido exibidos na Tabela 24, indicaram que não houve variação entre lotes; entre épocas a sem secagem foi superior às demais e 6 meses, estatisticamente inferior. Entre tratamentos, a testemunha mostrou o menor índice de peróxido e H-24 h, PEG $-8 \mathrm{~atm}$ e PEG -6atm, os maiores índices. Portanto, o condicionamento aumentou em muito a produção de peróxidos das sementes tratadas, o que difere do sugerido por GAO et al. (1988). Valores aparentemente sem lógica foram apresentados pela testemunha em todas as épocas, o mesmo acontecendo nos tratamentos $\mathrm{H}-18$ e $\mathrm{H}-24$ h logo após a secagem.

Como já relatado anteriormente, os melhores tratamentos quanto à qualidade fisiológica foram os que atingiram os maiores teores de água (H-24 h e PEG), principalmente, em relação ao parâmetro condutividade elétrica, sendo as piores $\mathrm{H}-12 \mathrm{~h}$ e a testemunha; estes resultados são concordantes com os apresentados na Tabela 22 de teor de óleo, porém divergentes aos de índice de acidez e 
peróxido (Tabelas 23 e 24), onde o melhor tratamento foi a testemunha e os piores $\mathrm{H}-24$ h e PEG. Esta diferença foi apenas estatística, já que a qualidade do oleo analisada através dos índices de acidez e peróxido, mostrou que nenhum dos tratamentos apresentou resultados que o classificassem como um óleo de valor alimentício.

Portanto, apesar do condicionamento manter a integridade das membranas celulares como foi verificado nos testes de vigor, os resultados de acidez e peróxido indicaram uma aceleração dos processos de deterioração do óleo, presente nas sementes.

Tabela 23 - Indice de acidez (mg $\mathrm{KOH} / \mathrm{g})$ : comparação de valores médios de lotes, tratamentos e épocas de sementes de soja condicionadas fisiologicamente, posteriormente secas em ambiente natural e finalmente armazenadas por 6 meses. Piracicaba, $1992 / 93$.

\begin{tabular}{|c|c|c|c|c|c|}
\hline \multirow{2}{*}{ Tratamento } & \multicolumn{5}{|c|}{ Lotes } \\
\hline & L I & $\mathrm{L} \quad$ I I & $L$ I I I & L IV & Médias \\
\hline Testemunha & 1,577 & 1,605 & 1,667 & 1,770 & $1,655^{\mathrm{A}}$ \\
\hline$H-12 h$ & 1,769 & 1,679 & 1,828 & 1,704 & $1,745^{\mathrm{AB}}$ \\
\hline $\mathrm{H}-18 \mathrm{~h}$ & 1,941 & 1,880 & 1,737 & 1,950 & $1,877^{\mathrm{BC}}$ \\
\hline$H-24 h$ & 1,905 & 1,988 & 1,940 & 2,085 & $1,979^{C D}$ \\
\hline $\mathrm{PEG}-8 \mathrm{~atm}$ & 2,256 & 2,205 & 1,988 & 2,207 & $2,164^{D}$ \\
\hline$P E G-6 a t m$ & 2,544 & 2,406 & 2,246 & 2,354 & $2,387^{\mathrm{E}}$ \\
\hline \multicolumn{6}{|c|}{ 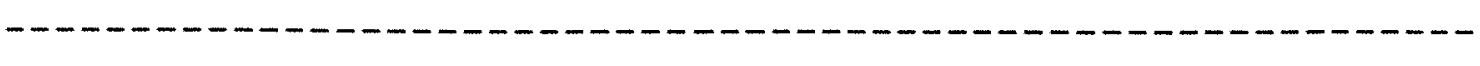 } \\
\hline Médias & $1,998^{\mathrm{a}}$ & $1,960^{8}$ & $1,901^{\mathrm{a}}$ & $2,012^{\mathrm{a}}$ & \\
\hline
\end{tabular}


Tabela 23 - fndice de acidez (mg $\mathrm{KOH} / \mathrm{g}$ ): comparação de valores médios de lotes, tratamentos e épocas de sementes de soja condicionadas fisiologicamente, posteriormente secas em ambiente natural e finalmente armazenadas por 6 meses. Piracicaba, 1992/93. Continuação.

\begin{tabular}{|c|c|c|c|c|c|}
\hline \multirow{2}{*}{ Tratamento } & \multicolumn{5}{|c|}{ Epocas } \\
\hline & Sem secagem & Com secagem & 3 meses & 6 meses & Médias \\
\hline Testemunha & $1,474^{\mathrm{Aa}}$ & $1,607^{\mathrm{Aa}}$ & $2,001^{\mathrm{Ab}}$ & $1,537^{\mathrm{Aa}}$ & 1,655 \\
\hline$H-12 h$ & $1,429^{\mathrm{Aa}}$ & $1,652^{\mathrm{Aab}}$ & $1,914^{\mathrm{Ab}}$ & $1,984^{\mathrm{Bb}}$ & 1,745 \\
\hline$H-18 h$ & $1,473^{\mathrm{Aa}}$ & $1,362^{\mathrm{Aa}}$ & $2,010^{\mathrm{Ab}}$ & $2,664^{\mathrm{Dc}}$ & 1,877 \\
\hline$H-24 h$ & $1,440^{\mathrm{Aa}}$ & $2,583^{\mathrm{cb}}$ & $1,670^{\mathrm{A}}$ & $2,224^{\mathrm{BCb}}$ & 1,979 \\
\hline $\mathrm{PEG}-8 \mathrm{~atm}$ & $1,623^{\mathrm{ABa}}$ & $2,135^{\mathrm{Bb}}$ & $2,435^{\mathrm{Bb}}$ & $2,463^{\mathrm{CDb}}$ & 2,164 \\
\hline PEG-6atm & $1,982^{\mathrm{Ba}}$ & $2,489^{\mathrm{BCb}}$ & $1,839^{\mathrm{Aa}}$ & $3,240^{\mathrm{Ec}}$ & 2,387 \\
\hline \multicolumn{6}{|c|}{ 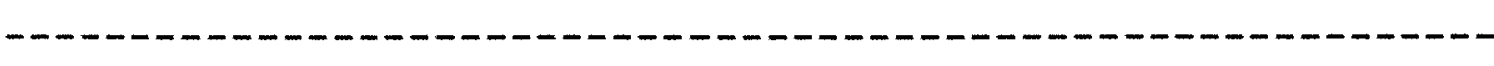 } \\
\hline Médias & 1,570 & 1,971 & 1,978 & 2,352 & \\
\hline \multirow[t]{2}{*}{ C.V. $\%$} & \multicolumn{5}{|l|}{9,660} \\
\hline & \multicolumn{5}{|c|}{ Epocas } \\
\hline Tratamento & Sem secagem & Com secagem & 3 meses & 6 meses & Médias \\
\hline L I & 1,530 & 2,112 & 2,020 & 2,332 & $1,998^{A}$ \\
\hline L I I & 1,567 & 1,929 & 1,938 & 2,407 & $1,960^{\mathrm{A}}$ \\
\hline$L$ III & 1,627 & 1,816 & 1,898 & 2,263 & $1,901^{\mathrm{A}}$ \\
\hline L IV & 1,557 & 2,028 & 2,056 & 2,406 & $2,012^{A}$ \\
\hline \multicolumn{6}{|c|}{ Médias $1,570^{\mathrm{a}} \quad 1,971^{\mathrm{b}} \quad 1,978^{\mathrm{b}} \quad 2,352^{\mathrm{c}}$} \\
\hline C.V. \% & 9,660 & & & & \\
\hline
\end{tabular}

Médias seguidas da mesma letra, minúsculas (nas linhas) e maísculas (nas colunas), não diferem entre si pelo teste de Tukey, ao nível de $5 \%$ de probabilidade. 
Tabela 24 - Indice de peróxido (meq $\mathrm{O}_{2} / 1000 \mathrm{~g}$ ): comparação de valores médios de lotes, tratamentos e épocas de sementes de soja condicionadas fisiologicamente, posteriormente secas em ambiente natural e finalmente armazenadas por 6 meses. Piracicaba, $1992 / 93$.

\begin{tabular}{|c|c|c|c|c|c|}
\hline \multirow{2}{*}{ Tratamento } & \multicolumn{5}{|c|}{ Lotes } \\
\hline & L I & L I I & L I I I & L IV & Médias \\
\hline Testemunha & 30,917 & 25,508 & 21,296 & 28,348 & $26,277^{A}$ \\
\hline$H-12 h$ & 49,585 & 45,898 & 48,171 & 55,805 & $49,736^{\mathrm{B}}$ \\
\hline$H-18 h$ & 51,869 & 46,668 & 51,491 & 48,967 & $49,705^{B}$ \\
\hline$H-24 h$ & 91,453 & 80,020 & 72,937 & 75,230 & $79,607^{c}$ \\
\hline PEG-8atm & 65,568 & 73,099 & 71,902 & 72,619 & $70,730^{c}$ \\
\hline PEG-6atm & 68,811 & 91,133 & 72,291 & 79,398 & $77,462^{c}$ \\
\hline \multicolumn{6}{|c|}{ Médias $\quad 56,640^{\mathrm{a}} \quad 55,572^{\mathrm{a}} \quad 52,224^{\mathrm{a}} \quad 56,876^{\mathrm{a}}$} \\
\hline C.V. \% & 4,410 & & & & \\
\hline \multirow{2}{*}{ Tratamento } & \multicolumn{5}{|c|}{ Epocas } \\
\hline & Sem secagem & Com secagem & 3 meses & 6 meses & Médias \\
\hline Test emunha & $6,749^{\mathrm{Aa}}$ & $32,729^{\mathrm{Bb}}$ & $73,769^{A B C}$ & $27,329^{A b}$ & 26,277 \\
\hline $\mathrm{H}-12 \mathrm{~h}$ & $26,681^{8 \mathrm{a}}$ & $32,603^{B a}$ & $82,624^{\mathrm{Bb}}$ & $84,188^{\mathrm{Bb}}$ & 49,736 \\
\hline$H-18 h$ & $42,934^{\mathrm{cb}}$ & $21,526^{\mathrm{Aa}}$ & $51,781^{\mathrm{Ab}}$ & $125,539^{c c}$ & 49,705 \\
\hline$H-24 h$ & $43,161^{\mathrm{Ca}}$ & $157,462^{\mathrm{DC}}$ & $55,956^{\mathrm{Aa}}$ & $104,925^{\mathrm{BCb}}$ & 79,607 \\
\hline PEG-8atm & $46,128^{\mathrm{ca}}$ & $79,142^{c b c}$ & $62,500^{\mathrm{ABab}}$ & $109,381^{\mathrm{Bcc}}$ & 70,730 \\
\hline PEG-6atm & $37,149^{\mathrm{BCa}}$ & $73,215^{\mathrm{cb}}$ & $60,851^{\mathrm{ABb}}$ & $215,427^{\mathrm{DC}}$ & 77,462 \\
\hline$-\cdots-\cdots-\cdots$ & -------1 & $--------n$ & -------- & --------- & $\ldots-\cdots$ \\
\hline Médias & 29,131 & 52,731 & 63,769 & 94,794 & \\
\hline
\end{tabular}

C.V. $\% \quad 4,410$ 
Tabela 24 - Indice de peróxido (meq $\mathrm{O}_{2} / 1000 \mathrm{~g}$ ): comparação de valores médios de lotes, tratamentos e épocas de sementes de soja condicionadas fisiologicamente, posteriormente secas em ambiente natural e finalmente armazenadas por 6 meses. Piracicaba, 1992/93. Continuação.

\begin{tabular}{lccrrr}
\hline & \multicolumn{5}{c}{ Epocas } \\
\cline { 2 - 6 } Tratamento & Sem secagem & Com secagem & 3 meses & 6 meses & Médias \\
\hline L I & 30,302 & 50,109 & 61,117 & 110,080 & $56,640^{\mathrm{A}}$ \\
L I I & 27,920 & 57,803 & 67,929 & 86,376 & $55,572^{\mathrm{A}}$ \\
L I I I & 28,727 & 48,696 & 61,176 & 86,367 & $52,224^{\mathrm{A}}$ \\
L IV & 29,628 & 54,806 & 65,103 & 98,308 & $56,876^{\mathrm{A}}$ \\
\hline Médias & $29,131^{\mathrm{a}}$ & $52,731^{\mathrm{b}}$ & $63,769^{\mathrm{C}}$ & $94,794^{\mathrm{d}}$ & \\
\hline C.V. \% & 4,410 & & & & \\
\hline
\end{tabular}

Médias seguidas da mesma letra, minúsculas (nas linhas) e maísculas (nas colunas), não diferem entre si pelo teste de Tukey, ao nível de 5\% de probabilidade.

\subsubsection{Proteína Bruta}

A Tabela 25 referente ao teor de proteína bruta em sementes condicionadas, indicou que não houve variação entre os lotes; apenas o tratamento $\mathrm{H}-18 \mathrm{~h}$ mostrouse superior ao H-24 h, PEG -6 e PEG - 8atm e, entre épocas, 6 meses exibiu o pior desempenho. 
Tabela 25 - Proteína bruta (\% m.s.): comparação de valores médios de lotes, tratamentos e épocas de sementes de soja condicionadas fisiologicamente, posteriormente secas em ambiente natural e finalmente armazenadas por 6 meses. Piracicaba, $1992 / 93$

\begin{tabular}{|c|c|c|c|c|c|}
\hline \multirow{2}{*}{ Tratamento } & \multicolumn{5}{|c|}{ Lotes } \\
\hline & L I & L I I & L I I I & L IV & Médias \\
\hline Testemunha & 44,568 & 43,963 & 43,333 & 44,399 & $44,065^{\mathrm{ABC}}$ \\
\hline$H-12 h$ & 44,471 & 44,280 & 44,383 & 44,113 & $44,312^{\mathrm{AB}}$ \\
\hline$H-18 h$ & 45,205 & 45,121 & 44,829 & 45,849 & $45,251^{A}$ \\
\hline $\mathrm{H}-24 \mathrm{~h}$ & 44,129 & 43,514 & 43,086 & 43,905 & $43,658^{\mathrm{BC}}$ \\
\hline PEG-8atm & 43,897 & 43,374 & 43,205 & 43,277 & $43,438^{\mathrm{BC}}$ \\
\hline PEG-6atm & 43,622 & 43,283 & 42,767 & 42,789 & $43,115^{c}$ \\
\hline \multicolumn{6}{|c|}{ 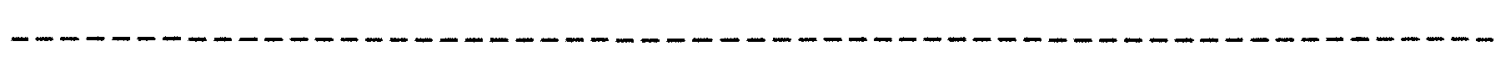 } \\
\hline Médias & $44,315^{a}$ & $43,922^{8}$ & $43,600^{\mathrm{a}}$ & $44,054^{\mathrm{a}}$ & \\
\hline C.V. $\%$ & 1,576 & & & & \\
\hline \multirow{2}{*}{ Tratamento } & \multicolumn{5}{|c|}{ Épocas } \\
\hline & Sem secagem & Com secagem & 3 meses & 6 meses & Médias \\
\hline Testemunha & $42,397^{\mathrm{cb}}$ & $44,918^{\mathrm{ABa}}$ & $44,804^{\mathrm{Aa}}$ & $44,148^{\mathrm{Aab}}$ & 44,065 \\
\hline$H-12 h$ & $44,269^{\mathrm{BCb}}$ & $46,539^{\mathrm{Aa}}$ & $44,260^{A b}$ & $42,191^{\mathrm{ABCb}}$ & b $\quad 44,312$ \\
\hline$H-18 h$ & $47,970^{\mathrm{Aa}}$ & $44,480^{\mathrm{ABb}}$ & $44,838^{A b}$ & $43,724^{\mathrm{ABb}}$ & 45,251 \\
\hline$H-24 h$ & $43,280^{\mathrm{BCbc}}$ & $44,337^{\mathrm{ABab}}$ & $45,729^{\mathrm{Aa}}$ & $41,301^{\mathrm{cc}}$ & 43,658 \\
\hline PEG-8atm & $45,247^{\mathrm{Ba}}$ & $44,909^{\mathrm{ABa}}$ & $40,333^{8 b}$ & $43,285^{\mathrm{ABCa}}$ & 43,438 \\
\hline $\mathrm{PEG}-6 \mathrm{~atm}$ & $42,931^{\mathrm{BCab}}$ & $43,666^{\mathrm{Bab}}$ & $44,168^{\mathrm{Aa}}$ & $41,700^{\mathrm{BCb}}$ & 43,115 \\
\hline Médias & 44,345 & 44,807 & 44,018 & 42,723 & \\
\hline
\end{tabular}

C.V. \% 1,576 
Tabela 25 - Proteína bruta (\% m.s.): comparação de valores médios de lotes, tratamentos e épocas de sementes de soja condicionadas fisiologicamente, posteriormente secas em ambiente natural e finalmente armazenadas por 6 meses. Piracicaba, 1992/93. Continuação.

\begin{tabular}{lccccc}
\hline & \multicolumn{5}{c}{ Épocas } \\
\cline { 2 - 6 } Tratamento & Sem secagem & Com secagem & 3 meses & 6 meses & Médias \\
\hline L I & 44,489 & 44,477 & 44,495 & 43,799 & $44,315^{A}$ \\
L II & 44,765 & 44,767 & 43,469 & 42,692 & $43,922^{A}$ \\
L III & 44,125 & 44,418 & 43,955 & 41,907 & $43,600^{A}$ \\
L IV & 44,002 & 45,569 & 44,153 & 42,498 & $44,054^{A}$ \\
\hline Médias & $43,345^{\mathrm{a}}$ & $44,807^{\mathrm{a}}$ & $44,018^{\mathrm{a}}$ & $42,723^{\mathrm{b}}$ & \\
\hline C.V. \% & 1,576 & & & & \\
\hline
\end{tabular}

Médias seguidas da mesma letra, minúsculas (nas linhas) e maiúsculas (nas colunas), não diferem entre si pelo teste de Tukey, ao nível de $5 \%$ de probabilidade.

Segundo PERL (1979), sementes de algodão embebidas por $24 \mathrm{~h}$ a $20^{\circ} \mathrm{C}$ tiveram um ganho expressivo no teor de proteínas (40\%); DELL'AQUILA \& TRITTO (1990) também obtiveram aumentos na síntese de proteína após o condicionamento de sementes de trigo, fatos estes, porém, divergentes dos relatados neste experimento, já que após o condicionamento os valores mantiveram-se praticamente inal terados. 


\subsubsection{Açúcares Totais}

A Tabela 26 contém a comparação de valores médios de açúcares totais em sementes condicionadas; entre lotes não ocorreram variações, entre tratamentos $\mathrm{H}-18 \mathrm{~h}$ apresentou o menor teor e foi estatisticamente inferior a PEG -8atm e a testemunha. Entre épocas houve uma perda crescente de açúcares, alcançando o menor valor estatístico após 6 meses de armazenamento, com exceção de $\mathrm{H}-12 \mathrm{~h}$.

Segundo CHAMMA et al. (1990), a quantidade de carboidratos totais diminui com o avanço da deterioração, já que há um aumento do quociente respiratório que, sob condições aeróbicas, oxidam os açúcares e as gorduras, produzindo gás carbônico, água e energia. Com o armazenamento, as sementes também necessitam de energia para sobreviver, daí o menor teor de açúcares totais apresentados após 6 meses.

\subsubsection{Açúcares Redutores}

Através da Tabela 27 referente a valores de açúcares redutores presentes em sementes condicionadas, foi possível verificar que não houve diferenciação entre lotes e tratamentos; apenas a época 6 meses $(6 \mathrm{~m})$ mostrou-se estatisticamente inferior às demais. 
104

Tabela 26 - Açúcares totais (mg/g): comparação de valores médios de lotes, tratamentos e épocas de sementes de soja condicionadas fisiologicamente, posteriormente secas em ambiente natural e finalmente armazenadas por 6 meses. Piracicaba, $1992 / 93$

\begin{tabular}{|c|c|c|c|c|c|}
\hline \multirow{2}{*}{ Tratamento } & \multicolumn{5}{|c|}{ Lotes } \\
\hline & L I & L I I & L II I & L IV & Médias \\
\hline Testemunha & 292,304 & 289,049 & 308,002 & 284,090 & $293,361^{\mathrm{A}}$ \\
\hline$H-12 h$ & 286,038 & 275,099 & 287,201 & 272,523 & $280,215^{\mathrm{AB}}$ \\
\hline$H-18 h$ & 255,463 & 261,585 & 255,463 & 249,533 & $255,511^{\mathrm{B}}$ \\
\hline$H-24 h$ & 267,664 & 243,021 & 252,836 & 297,653 & $265,293^{\mathrm{AB}}$ \\
\hline PEG-8atm & 254,542 & 279,815 & 300,228 & 331,044 & $291,407^{\mathrm{A}}$ \\
\hline PEG-6atm & 289,292 & 217,743 & 272,234 & 276,121 & $265,848^{\mathrm{AB}}$ \\
\hline \multicolumn{6}{|c|}{ Médias $\quad 274,217^{\mathrm{a}} 261,052^{\mathrm{a}} 279,327^{\mathrm{a}} 285,161^{\mathrm{a}}$} \\
\hline \multirow[t]{2}{*}{ C.V. \% } & \multicolumn{5}{|l|}{12,308} \\
\hline & \multicolumn{5}{|c|}{ Epocas } \\
\hline Tratamento & Sem secagem & Com secagem & 3 meses & 6 meses & Médias \\
\hline Testemunha & $338,135^{\mathrm{ha}}$ & $284,430^{\mathrm{ABab}}$ & $296,825^{\mathrm{hab}}$ & $254,055^{\mathrm{ABb}}$ & 293,361 \\
\hline$H-12 h$ & $289,630^{A B t}$ & $267,373^{8 a}$ & $286,863^{\mathrm{Az}}$ & $276,996^{\mathrm{A}}$ & 280,215 \\
\hline$H-18 h$ & $255,510^{8 b}$ & $321,320^{\mathrm{ABa}}$ & $275,682^{\mathrm{d} a b}$ & $169,532^{\mathrm{Cc}}$ & 255,511 \\
\hline$H-24 h$ & $281,855^{\mathrm{ABa}}$ & $316,217^{\mathrm{ABz}}$ & $271,698^{\mathrm{Az}}$ & $191,404^{\mathrm{BCb}}$ & 265,293 \\
\hline PEG-8atm & $317,482^{\mathrm{ABa}}$ & $344,558^{\mathrm{Aa}}$ & $282,925^{\mathrm{Asb}}$ & $220,663^{\mathrm{ABC}}$ & 291,407 \\
\hline $\mathrm{PEG}-6 \mathrm{~atm}$ & $279,180^{\mathrm{ABgb}}$ & $333,280^{\mathrm{ABa}}$ & $256,290^{\mathrm{Ab}}$ & $186,641^{\mathrm{BCC}}$ & 265,848 \\
\hline$\ldots$ & 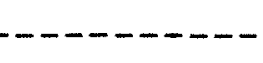 & 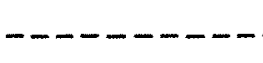 & 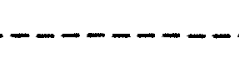 & ---- & $-\ldots-\cdots$ \\
\hline Médias & 293,632 & 311,196 & 278,380 & 216,548 & \\
\hline
\end{tabular}


Tabela 26 - Açúcares totais (mg/g): comparação de valores médios de lotes, tratamentos e épocas de sementes de soja condicionadas fisiologicamente, posteriormente secas em ambiente natural e finalmente armazenadas por 6 meses. Piracicaba, 1992/93. Continuação.

\begin{tabular}{lccccc}
\hline & \multicolumn{5}{c}{ Épocas } \\
\cline { 2 - 6 } Tratamento & Sem secagem & Com secagem & 3 meses & 6 meses & Médias \\
\hline L I & 300,763 & 321,728 & 283,200 & 191,177 & $274,217^{\mathrm{A}}$ \\
L I I & 276,555 & 275,197 & 267,192 & 225,264 & $261,052^{\mathrm{A}}$ \\
L I I I & 305,847 & 324,803 & 283,590 & 203,069 & $279,327^{\mathrm{A}}$ \\
L IV & 291,363 & 323,057 & 279,540 & 246,683 & $285,161^{\mathrm{A}}$ \\
\hline Médias & $293,632^{\mathrm{ab}}$ & $311,196^{\mathrm{a}}$ & $278,380^{\mathrm{b}}$ & $216,548^{\mathrm{c}}$ & \\
\hline C.V.\% & 12,308 & & & & \\
\hline
\end{tabular}

Médias seguidas da mesma letra, minúsculas (nas linhas) e maiúsculas (nas colunas), não diferem entre si pelo teste de Tukey, ao nível de $5 \%$ de probabilidade.

Os tratamentos de condicionamento não alteraram o teor de açúcares redutores; PERL (1979) também obteve resultados semelhantes após embeber sementes de a lgodão por $24 \mathrm{~h} \mathrm{a} 20^{\circ} \mathrm{C}$. Com o armazenamento e a consequente deterioração, a quantidade de açúcares redutores diminuiu, confirmando as observações de EDJE \& BURRIS (1970), mas divergindo das obtidas por sHARMA et al. (1990). 
Tabela 27 - Açúcares redutores $(\mathrm{mg} / \mathrm{g})$ : comparação de valores médios de lotes, tratamentos e épocas de sementes de soja condicionadas fisiologicamente, posteriormente secas em ambiente natural e finalmente armazenadas por 6 meses. Piracicaba, $1992 / 93$.

\begin{tabular}{|c|c|c|c|c|c|}
\hline \multirow{2}{*}{ Tratamento } & \multicolumn{5}{|c|}{ Lotes } \\
\hline & L I & L I I & L I I I & L IV & Médias \\
\hline Test emunha & 0,901 & 1,021 & 1,127 & 0,940 & $0,997^{A}$ \\
\hline$H-12 h$ & 0,785 & 1,116 & 1,058 & 1,065 & $1,006^{\AA}$ \\
\hline $\mathrm{H}-18 \mathrm{~h}$ & 0,784 & 1,044 & 1,133 & 0,845 & $0,951^{\mathrm{A}}$ \\
\hline$H-24 h$ & 1,009 & 0,958 & 1,000 & 1,075 & $1,011^{A}$ \\
\hline PEG-8atm & 0,911 & 0,841 & 0,775 & 0,848 & $0,844^{\mathrm{A}}$ \\
\hline $\mathrm{PEG}-6 \mathrm{~atm}$ & 0,822 & 0,704 & 0,740 & 1,128 & $0,848^{A}$ \\
\hline \multicolumn{6}{|c|}{ 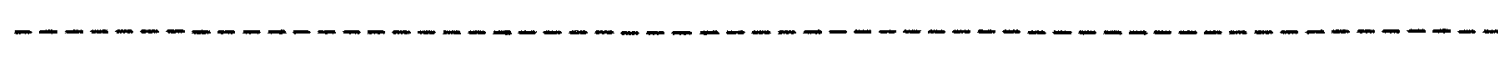 } \\
\hline Médias & $0,869^{\mathrm{a}}$ & $0,947^{\mathrm{a}}$ & $0,972^{\mathrm{a}}$ & $0,983^{\mathrm{a}}$ & \\
\hline \multirow[t]{2}{*}{ C.V. $\%$} & \multicolumn{5}{|l|}{24,887} \\
\hline & \multicolumn{5}{|c|}{ Epocas } \\
\hline Tratamento & Sem secagem & Com secagem & 3 meses & 6 meses & Médias \\
\hline Testemunha & $1,010^{\mathrm{Aa}}$ & $0,829^{\mathrm{Ba}}$ & $1,227^{\mathrm{Aa}}$ & $0,922^{\mathrm{Aa}}$ & 0,997 \\
\hline $\mathrm{H}-12 \mathrm{~h}$ & $0,950^{\mathrm{Aa}}$ & $0,900^{\mathrm{Ba}}$ & $1,086^{\mathrm{Aa}}$ & $1,088^{\mathrm{Aa}}$ & 1,006 \\
\hline $\mathrm{H}-18 \mathrm{~h}$ & $0,990^{\mathrm{Aa}}$ & $1,088^{\mathrm{ABa}}$ & $0,940^{\mathrm{Aa}}$ & $0,788^{\mathrm{Aa}}$ & 0,951 \\
\hline$H-24 h$ & $0,951^{\mathrm{Aa}}$ & $1,112^{\mathrm{ABa}}$ & $1,081^{A a}$ & $0,898^{\mathrm{Aa}}$ & 1,011 \\
\hline $\mathrm{PEG}-8 \mathrm{~atm}$ & $1,000^{\mathrm{Aab}}$ & $1,419^{\mathrm{Aa}}$ & $0,865^{A b}$ & $0,092^{\mathrm{Bc}}$ & 0,844 \\
\hline PEG-6atm & $1,097^{\mathrm{Aa}}$ & $1,278^{\mathrm{ABa}}$ & $0,984^{\mathrm{Aa}}$ & $0,035^{\mathrm{Bb}}$ & 0,848 \\
\hline \multicolumn{6}{|c|}{ 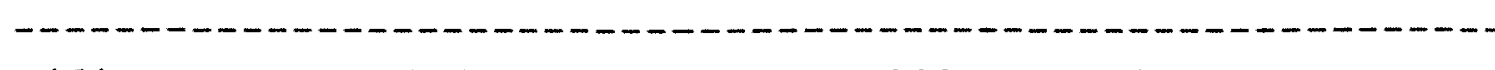 } \\
\hline Médias & 1,000 & 1,104 & 1,030 & 0,637 & \\
\hline
\end{tabular}

C. V. \% 
Tabela 27 - Açúcares redutores (mg/g): comparação de valores médios de lotes, tratamentos e épocas de sementes de soja condicionadas fisiologicamente, posteriormente secas em ambiente natural e finalmente armazenadas por 6 meses. Piracicaba, 1992/93. Continuação.

\begin{tabular}{lccccc}
\hline & \multicolumn{5}{c}{ Épocas } \\
\cline { 2 - 6 } Tratamento & Sem secagem & Com secagem & 3 meses & 6 meses & Médias \\
\hline L I & 0,972 & 1,069 & 0,865 & 0,568 & $0,869^{\mathrm{A}}$ \\
L I I & 0,974 & 1,034 & 1,103 & 0,679 & $0,947^{\mathrm{A}}$ \\
L I I I & 0,996 & 1,108 & 1,036 & 0,749 & $0,972^{\mathrm{A}}$ \\
L IV & 1,057 & 1,207 & 1,117 & 0,552 & $0,983^{\mathrm{A}}$ \\
\hline Médias & $1,000^{\mathrm{a}}$ & $1,104^{\mathrm{a}}$ & $1,030^{\mathrm{a}}$ & $0,637^{\mathrm{b}}$ & \\
\hline C.V. \% & 24,887 & & & & \\
\hline
\end{tabular}

Médias seguidas da mesma letra, minúsculas (nas linhas) e maiúsculas (nas colunas), não diferem entre si pelo teste de Tukey, ao nível de $5 \%$ de probabilidade.

o condicionamento com soluções osmóticas quando comparado aos tratamentos com hidratação lenta, proporcionou aumentos no teor de açúcares redutores; porém, após 6 meses de armazenamento, houve uma elevada perda, indicando que o uso do PEG pode ter contribuído para a diminuição do nível de açúcares redutores. 
Portanto, não foi notada coerência entre os resultados de açúcares totais e açúcares redutores quando comparados com os parâmetros de qualidade fisiológica. Os melhores tratamentos no teste de condutividade elétrica, foram os piores quando submetidos às determinações de composição química citadas anteriormente.

\subsection{Considerações Gerais}

De maneira geral, foi observado que o condicionamento fisiológico melhorou o desempenho das sementes de soja; lotes de vigor mais baixo (L I e III) alcançaram os de vigor mais elevados (L II e IV), benefício este porém, praticamente perdido com a secagem.

- condicionamento sem secagem posterior reduziu a saída de eletrólitos, como mostrou o teste de condutividade elétrica, possivelmente por permitir um controle da entrada de água enquanto as membranas se restabeleciam.

Quanto a manutenção dos benefícios do condicionamento durante o armazenamento das sementes, foi notada uma queda tanto na qualidade fisiológica das sementes, quanto na qualidade do óleo, não justificando o uso do condicionamento para elevar a longevidade das sementes. 
Em relação às possíveis vantagens do condicionamento com soluções osmóticas ou com hidratação lenta, estas parecem não existirem, sendo mais importante o grau de umidade final atingido pelas sementes, já que os melhores resultados foram obtidos com os tratamentos que possuíam teores de água mais elevados (H-24 h e PEG).

o condicionamento não "revigorou" as sementes como já foi descrito anteriormente pela literatura; apenas alterou a permeabilidade das membranas celulares e, em escala menor, os parâmetros fisiológicos.

Não houve coerência entre os resultados de qualidade fisiológica e os de composição química; as principais alterações bioquímicas promovidas pelo condicionamento foram aumentos nos índices de acidez e peróxido, o que caracterizou a perda de qualidade do óleo.

A metodologia de condicionamento empregada neste trabalho, em camadas de papel-toalha umedecidas, mostrou-se adequada dentro dos períodos de tempo estudados.

o tratamento de condicionamento fisiologico tradicional, com secagem subsequente, não apresentou os efeitos benéficos reportados em outras culturas. Por permitir um controle da entrada de água enquanto as membranas se restabelecem, a técnica de condicionamento traz vantagens para o desenvolvimento da cultura de soja, principalmente quando são empregadas sementes com baixo grau de umidade, onde o dano por embebição é eminente. 
o condicionamento fisiológico, portanto, representa uma linha de pesquisa das mais promissoras; novos trabalhos com sementes de soja parecem ser necessários, utilizando outras metodologias, tratamentos com teores de água mais elevados, lotes de sementes com qualidade fisiológica mais discrepantes, e cultivares diferenciados. 


\section{CONCLUSÕES}

A análise dos dados $e$ interpretação dos resultados, considerando o condicionamento fisiológico de sementes de soja (Glycine max L.) permitiram concluir que:

1. O condicionamento fisiológico proporciona benefícios imediatos ao desempenho de sementes de soja, mas os mesmos são revertidos com a posterior secagem e o armazenamento;

2. A embebição controlada, sem uso de substâncias químicas (hidratação lenta) e o condicionamento osmótico fornecem resultados semelhantes;

3. Dentro dos limites estudados, a melhor resposta ao condicionamento fisiológico é proporcional ao nível de umidade empregado. 


\section{REFERÊNCIAS BIBLIOGRÁFICAS}

A-AS-SAQUI, M. \& CORLETO, A. Effect of seed presowing hardening on seedling emergence of four forage species. Seed Science \& Technology, Zürich, 6: 701-9, 1978.

ABDUL-BAKI, A.A. \& BAKER, J. Are changes in celular organelles or membranes related to vigour loss in seeds? Seed Science \& Technology, Zürich, 1: 89-125, 1973.

ALI, A.; MACHADO, V.S.; HAMILL, A.S. Osmoconditioning of tomato and onion seeds. Scientia Horticulturae, Amsterdam, 43(3/4): 213-24, 1990 .

ANDERSON, J.D. Adenylate metabolism of embrionic axes from deteriorated soybean seeds. Plant Physiology, Lancaster, $59: 610-4,1977$. 
ARGERICH, C.A.; BRADFORD, K.J.; TARQUIS, A.M. The effects of priming and ageing on resistance to deterioration of tomato seeds. Journal of Experimental Botany, oxford, $40(214): 593-8,1989$.

ARMSTRONG, H. \& MCDONALD, M.B. Effects of osmoconditioning on water uptake and electrical conducting in soybean seeds. Seed Science \& Technology, Zürich, 20: 391-400, 1992.

ASSOCIATION OF OFFICIAL ANALYTICAL CHEMISTS. Official methods of analysis. 14.ed. Arlington, 1984. 252p.

BANERJEE, S.K. Observations on the initiation of seed deterioration and its localization in barley and onion. Seed Science \& Technology, Zürich, 6: 1025-8, 1978.

BASAVARAJAPPA, B.S.; SHETTY, H.S.; PRAKASH, H.S. Membrane deterioration and other biochemical changes, associated with accelerated ageing of maize seeds. Seed Science \& Technology, Zürich, 19: 279-86, 1991.

BASRA, A.S.; BEDI, S.; MALIK, C.P. Accelerated germination of maize seeds under chilling stress by osmotic priming and associated changes in embryo phospholipids. Annals of Botany, Oxford, 61(5):635-9, 1988 . 
BASU, R.N. Physico-chemical control of seed deterioration. Seed Research, New Delhi, 4: 15-23, 1976.

BERRIE, A.M.M. \& DRENNAN, D.S.H. The effect of hidrationdehydration on seed germination. New Phytologist, London, $70: 135-42, \quad 1971$.

BEWLEY, J.D. Membrane changes in seeds as related to germination and the perturbations resulting from deterioration in storage. In: HEYDECKER, W., ed. Seed ecology. University Park, The Pennsylvania State University Press, 1973. p.27-45.

BEWLEY, J. D \& BLACK, M. Physiology and biochemistry of seeds in relation to germination. New York, SpringerVerlag, 1983. v.1, 306p.

BEWLEY, J.D. \& BLACK, M. Seed physiology of development and germination. New York, Plenum Press, 1985. 367p.

BHARATI, M.P.; LAWN, R.J.; BYTH, D.E. Effect of seed hydration-dehydration pre-treatment on germination of soybean 1 ines at sub-optimal temperatures. Australian Journal of Experimental Agriculture and Animal Husbandry, East Melbourne, 23(122): 309-17, 1983. Apud Seed Abstracts, Wall ingford, 7(7): 185, July 1984. (Resumo). 
BINO, R.J.; VRIES, J.N. de; KRAAK, H.L.; PIJLEN, J.G. van. Flow cytometric determination of nuclear replication stages in tomato seeds during priming and germination. Annals of Botany, Oxford, 69(3): 231-6, 1992.

BODSWORTH, S. \& BEWLEY, J.D. Osmotic priming of seeds of crops species with polyethylene glycol as a means of enhancing early and synchronous germination at cool temperatures. Canadian Journal of Botany, ottawa, 59: $672-6,1981$

BRADFORD, K.J. Manipulation of seed water relations via osmotic priming to improve germination under stress conditions. Hortscience, Alexandria, 21(5): 1105-12, 1986.

BRAMLAGE, W.J.; LEOPOLD, A.C.; PARRISH, D.J. Chilling stress to soybeans during imbibition. plant physiology, Lancaster, $61(2): 525-9,1978$.

BRASIL. Ministério da Agricultura. Regras para análise de sementes. Brasília, LANARV/SNAD/MA, 1980. 188p.

BROCKLEHURST, P.A.; DEARMAN, J.; DREW, R.L.K. Recent developments in osmotic treatment of vegetable seeds. Acta Horticulturae, The Hague, 215: 193-201, Oct. 1987. 
BURCH, T.A. \& DELOUCHE, J.C. Absorption of water by seeds. Proceedings of the Association of official Seed Analysts, Lansing, 49: 142-50, 1959.

BURGASS, R.W. \& POWELL, A.A. Evidence for repair processes in the envigoration of seeds by hydration. Annals of Botany, Oxford, 53: 753-7, 1984 .

BUSSEL, W.T. \& GRAY, D. Effects of pre-sowing seed treatments and temperatures on tomato seed germination and seedling emergence. Scientia Horticulturae, Amsterdam, 5: $101-9,1976$

CARVALHO, N.M. de. O conceito de vigor em sementes. In: VIEIRA, R.D. \& CARVALHO, N.M. de. Testes de vigor em sementes. Jaboticabal, FUNEP, 1994. p.1-30.

CARVALHo, N.M. de \& NAKAGAWA, J. Sementes: ciência, tecnologia e produção. 3.ed. Campinas, Fundação Cargil1, 1988. $424 \mathrm{p}$.

CHAMMA, H.M.C.P.; MARCOS FILHO, J.; CROCOMO, O.J. Maturation of seeds of "Aroana" beans (Phaseolus vulgaris L.) and its influence on the storage potential. Seed science \& Technology, Zürich, 18: 371-82, 1990. 
CHAUHAN, K.P.S. The incidence of deterioration and its localization in aged seeds of soybean and barley. Seed Science \& Technology, Zürich, 13: 769-73, 1985.

CHIMMAD, V.P.; SUBBAIAH, K.V.; JANARDHAN, K.V. OSmOconditioning as a means of seed invigoration in greengram. Current Research. University of Agricultural Sciences, Bangalore, 16(1):6-8, 1987. Apud Seed Abstracts, Wa1 1 ingford, 12(2):56, Feb. 1989. (Resumo).

CHING, T.M. Biochemical aspects of seed vigor. Seed Science \& Technology, Zürich, 1: 73-8, 1973.

CHOUDHURI, N. \& BASU, R.N. Maintenance of seed vigour and viability of onion (Allium cepa L.). Seed science \& Technology, Zürich, 16:51-61, 1988 .

COLE, D.F. \& WHEELER, J.E. Effect of pregermination treatments on germination and growth of cottonseed at subotimal temperatures. Crop Science, Madison, 14:451-4, May/June 1974.

DELL'AQUILA, A. \& TRITTO, V. Ageing and osmotic priming in wheat seeds: effects upon certain components of seed quality. Annals of Botany, Oxford, 65(1): 21-6, Jan. 1990. 
118.

DELOUCHE, J.C. Physiology of seed storage. In: COM. AND SORGHUM RES. CONF., 23., 1968. Proceedings. American Seed Trade Association, 1968. p.83-90.

DELOUCHE, J.C. Planting seed quality. Mississipi, Mississippi State University/Agricultural Experiment station, 1969. (Paper, 1721).

DELOUCHE, J.C. \& BASKIN, C.C. Accelerated aging techniques for predicting the relative storability of seed lots. Seed Science \& Technology, Zürich, 1: 427-52, 1973.

De ROBERTIS, E.D. \& De ROBERTIS, E.M.F. Bases da biologia celular e molecular. Rio de Janeiro, Ed. Guanabara, 1993. $307 \mathrm{p}$.

DEY (PATHAK), G. \& MUKHERJEE, R.K. Invigoration of dry seeds with physiologically active chemicals in organic solvents. Seed Science \& Technology, Zürich, 16(1): 145-53, 1988.

DONI FILHO, L. Efeitos do condicionamento fisiológico no comportamento de sementes de feijão (Phaseolus vulgaris L.). Piracicaba, 1992. 108p. (Doutorado - Escola Superior de Agricultura "Luiz de Queiroz"/USP). 
DUboIS, M.: GILlES, K.A.; HAMILTON, J.K.; REBERS, P.A.; SMITH, F. Colorimetric method for determination of sugars and related substances. Analytical Chemistry, Washington, 28: $350-6,1956$.

EDJE, O.T. \& BURRIS, J.S. Physiological and biochemical changes in deteriorating soybean seeds. Proceedings of the Association of official Seed Analysts, Lansing, 60: $158-66,1970$.

EIRA, M.T.S. Condicionamento osmótico de sementes de alface (Lactuca sativa L.): efeitos sobre a germinação e desempenho sob estresses hídrico, salino e térmico. Piracicaba, 1988. 90p. (Mestrado - Escola Superior de Agricultura "Luiz de Queiroz"/USP).

FEHR, W.E. \& CAVINESS, C.E. Stages of soybean development. Ames, Iowa State University/Cooperative Extension Service, 1980. 11p. (Special Report, 80).

FRANÇA NETO, J.B.; HENNING, A.A.; COSTA, N.P. Estudo da deterioração da semente de soja no solo. In: EMPRESA BRASILEIRA DE PESQUiSA AGROPECUARIA. Centro Nacional de Pesquisa de Soja. Resultados de pesquisa de soja 1984/85. Londrina, EMBRAPA/CNPSo, 1985. p.440-5. 
FU, J.R.; JI, D.Y.; ZHANG, B.Z. Preliminary report on the promotive effects of osmoconditioning on the germination of several crop seeds. Acta Scientiarum Naturalium Universitatis Sunyatseni, (2): 139-40, 1983. Apud Seed Abstracts, Wallingford, 6(11): 355, Nov. 1983. (Resumo).

FU, J.R.; LU, X.H.; CHEN, R.Z.; ZHANG, B.Z.; LIV, Z.S.; LI, Z.S.; CAI, D.Y. Osmoconditioning of peanut (Arachis hypogea L.) seeds with PEG to improve vigour and some biochemical activities. Seed Science Technology, Zürich, 16: 197-212, 1988 .

GAO, I.A.; YANG, X.C.; LIU, T. Effect of PEG on physiological damage in irradiated soybean seeds. Acta Agricultural Universitatis Jilinensis, Changchun, 10(1): 56-60, 1988. Apud Seed Abstracts, Wallingtoford, 13(1): 39, Jan. 1993. (Resumo)

GORECKI, R.J. \& HARMAN, G.E. Effects of antioxidants on viability and vigour of ageing pea seeds. Seed Science \& Technology, Zürich, 15: 109-17, 1987.

GUEDES, A.C. \& CANTLIFFE, D.J. Germination of lettuce seeds at high temperature after seed priming. Journal of the American Society for Horticultural science, St. Joseph, 105(6): 777-81, 1980 . 
HADAS, A. Water uptake and germination of leguminous seeds under changing external water potential in osmotic solutions. Journal of Experimental Botany, Oxford, $27(98): 480-9$, June 1976.

HANSON, A.D. The effects of imbibition drying treatments on wheat seeds. New Phytologist, London, 72: 1063-73, 1973.

HARRINGTON, J.F. Seed storage and longevity. In: KOZLOWSKI, T.T., ed. Seed biology. New York, Academic Press, 1972. v. 3, p. $145-245$.

HARTMAN, L. \& ESTEVES, W. Tecnologia de óleos e gorduras vegetais. São Paulo, Secretaria da Indústria, Comércio, Ciência e Tecnologia, 1982. 169 p.

HEGARTY, T.W. The possibility of increasing field establishment by seed hardening. Horticultural Review, Edinburgh, 10: $59-64,1970$.

HEGARTY, T.W. Seed activation and germination under moisture strees. New Phytologist, London, 78: 349-59, 1977a.

HEGARTY, T.W. Seed and seedling susceptibility to phased moisture stress in soil. Journal of Experimental Botany, Oxford, 28(104): 659-68, June $1977 \mathrm{~b}$. 
HEGARTY, T.W. The physiology of seed hydratation and dehydration between water stress and the control of germination: a review. Plant, Cell and Environment, Oxford, 1: 101-19, 1978 .

HELSEL, D.G.; HELSEL, Z.R.; MINOR, H.C. Field studies on osmoconditioning soybeans. Field Crops Research, Amsterdam, 14(3): 291-7, 1986. Apud Seed Abstracts, Wallingford, 10(2): 51, Feb. 1987. (Resumo).

HENNING, A.A.; KRZYZANOWSKI, F.C.; FRANÇA NETO, J.B.; YORINORI, J.T. Tratamento de sementes de soja com fungicidas. Anuário ABRASEM - 1992, Brasília, p.8-10, 1992 .

HEPPERLY, P.R. \& SINCLAIR, J.B. Aqueous polyethylene glycol solutions for treating soybean seeds with antibiotics. Seed Science \& Technology, Zürich, 5(4): 727-33, 1977.

HERNER, R.C. Germination under cold soil conditions. HortScience, Alexandria, 21(5): 1118-22, 1986.

HEYDECKER, W. Stress and seed germination. In: KHAN, A.A., ed. The physiology and biochemistry of seed dormancy and germination. Amsterdam, Elsevier/North-Ho1land, 1977. p. $240-82$. 
HEYDECKER, W. \& COOLBEAR, P. Seed treatments for improved performance; survey and attempted prognosis. Seed science \& Technology, Zürich, 5: 353-425, 1977.

HEYDECKER, W. \& WAINWRIGHT, H. More rapid and uniform germination of cyclamen persicum L. Scientia Horticulturae, Amsterdam, 5: 183-9, 1976.

HEYDECKER, W.; HIGGINS, J.; GULLIVER, R.L. Accelerated germination by osmotic seed treatment. Nature, London, $246(2): 42-4$, Nov. 1973 .

HEYDECKER, W.; HIGGING, J. ; TURNER, Y.J. Invigoration of seeds? Seed Science \& Technology, Zürich, 3: 881-8, 1975.

HOBBS, P.R. \& OBENDORF, R.L. Interaction of initial seed moisture and imbibitional temperature on germination and productivity of soybean. Crop Science, Madison, 12: 6647 , sept./Oct. 1972 .

IBRAHIM, A.E. \& ROBERTS, E.H. Viability of seeds. Journal of Experimental Botany, Oxford, 34(132): 620-30, 1983 .

JACKSON, W.T. Use of carbowaxes (polyethylene glycols) as osmotic agents. Plant Physiology, Rockville, 37(4): 5139,1962 . 
JACKSON, W.T. Mannitol-induced stimulation of elongation of root hairs of Agrotis alba L. Physiologia Plantarum, Copenhagen, 18: 24-30, 1965

KALOYEREAS, S.A. Rancidity as a factor in the loss of viability of pine and other seeds. Journal of the American Oil Chemist's society, Chicago, 35: 176-9, 1958.

KHAN, A.A.; PECK, N.H.; SAMIMY, C. Seed osmoconditioning: physiological and biochemical changes. Israel Journal of Botany, Jerusalem, 29(1/4): 133-44, 1980/81.

KHAN, A.A.; BRAUM, J.W.; TAO, K.L. ; MILLIER, W.F.; BENSIN, R.F. New methods for maintaining seed vigor and improving performance. Journal of Seed Technology, Lansing, 1(2): $33-57,1976$.

KHAN, A.A.; TAO, K.L.; KNYPL, J.S.; BORKOWSKA, B.; POWELL, L.E. Osmotic conditioning of seeds: physiological and biochemical changes. Acta Horticulturae, The Hague, 83: $267-78,1978$.

KNYPL, J.S. \& KHAN, A.A. Osmoconditioning of soybean seeds to improve performance at suboptimal temperatures. Agronomy Journa1, Madison, 73(1): 112-6, Jan./Feb. 1981. 
KNYPL, J.S.; JANAS, K.M.; KOSWIAK, A.R. Is enhanced vigouT in soybean dependent on activation of protein turnover during controlled hydration of seeds? Physiologie Vegetale, Montrouge, 18: 157-61, 1980.

KOOSTRA, P. \& HARRINGTON, J. Biochemical effects of age on membranal lipids of Cucumis sativus L. seed. Proceedings International seed Testing Association, Copenhagen, 34: $329-40,1973$.

LABOURIAU, L.G. A germinação das sementes. Washington, OEA, 1983. 174p. (OEA . Coleção de Monografias Científicas Biológica, 24).

LARSON, L.A. The effect soaking pea with or without seedcoats has on seeding growth. Plant Physiology, Lancaster, 43: 255-9, 1968 .

LOEFFLER, T.M.; TEKRONY, D.M.; EGLI, D.B. The bulk conductivity test as an indicator of soybean seed quality. Journal of Seed Technology, Lansing, 12(1): 37-53, 1988.

LORENZ, E.J.; COTHREN, J.T.; LONGER, D.E. Osmoconditioning and hormonal influences on soybean emergence at optimal and suboptimal temperatures. Journal of Seed Technology, Lansing, 12(2): 143-8, 1988 . 
LUCCA FILHO, O.A. Metodologia dos testes de sanidade de sementes. In: SOAVE, J, \& WETZEL, M.M.V.S., ed. Patologia de sementes. Campinas, Fundação Cargill, 1987. p. $276-98$.

LUZZATI, V. \& HUSSON, F. The structure of the liquidcrystalline phases of lipid-water systems. The Journal of Cel1 Biology, New York, 12: 207-19, 1962.

MARCOS FILHo, J. Germinação de sementes. In: SEMANA DE ATUAL IZAÇÃo EM PRODUÇÃO DE SEMENTES, 1., Piracicaba, 1986. Campinas, Fundação Cargi11, 1986. p.11-39.

MARCOS FILHO, J.; Cf́CERO, S.M.; SILVA, W.R. da. Avaliação da qualidade de sementes. Piracicaba, FEALQ, 1987. 230p.

MATTHEWS, S. Evaluation of techniques for germination and vigour studies. Seed Science \& Technology, Zürich, 9: $543-51,1981$.

MATTHEWS, S. Physiology of seed ageing. Outlook on Agriculture, Brackne 11, 14(2): 89-94, 1985 .

MATTHEWS, S. \& POWELl, A.A. Environmental and physiological constraints on field performance of seeds. Hortscience, Alexandria, 21(5): 1125-8, 1986 . 
MCKERSIE, B.D. \& SENARATNA, T. Membrane structure in germinating seeds. In: NOZZOLILLO, C.; LEA, P.J.; LOEWUS, F.A. Mobilization of reserves in germination, recent advances in phytochemistry. New York, Plenum Press, 1983. v.17, p. $29-52$.

MENG, X.D. \& LI, S.X. Improvement of vegetable soyabean seed vigour by controlled water absorption pretreatments. Acta Agricultural Universitat is Zhejangensis, Shandongs, 18(1): 51-5, 1992. Apud Seed Abstracts, Wallingford, 16(7): 285, July 1993. (Resumo).

MICHEL, B.E. \& KAUFMANN, M.R. The osmotic potential of PEG 6000. Plant Physiology, Lancaster, 51(5): 914-6, 1973.

MUHYADDIN, T. \& WIEBBE, H.J. Effects of seed treatments with polyethylene glycol (PEG) on emergence of vegetable crops. Seed Science \& Technology, Zürich, 17(1): 49-56, 1989.

MUKHERJEE, R.K. \& DEY(PATHAK), G. Stepwise hydration of soybean seed to prevent soaking injury and loss of viability during storage. Proceedings of the Indian National Science Academy, B. Bangalore, 51(4): 515-21, 1985. Apud Seed Abstracts, Wallingford, 9(12): 424, Dec. 1986. (Resumo). 
NATH, S.; COOLBEAR, P.; HAMPTON, J.G. Hydration-dehydration treatments to protect or repair stored "karamu" wheat seeds. Crop Science, Madison, 31: 822-6, May/June 1991.

NELSON, N. A photometric adaptation of the Somogyi method for determination of glucose. Journal of Biological Chemistry, Baltimore, 153: 375-80, 1944 .

OBENDORF, R.L. \& HOBBS, P.R. Effect of seed moisture on temperature sensitivity during imbibition of soybean. Crop Science, Madison, 10(1):563-6, Sept./Oct. 1970.

OLIVEIRA, M.A.; MATTHEWS, S.; POWELL, A.A. The role of split seed coats in determining seed vigour in commercial seed lots of soybean, as measured by the electrical conductivity test. Seed Science and Technology, Zürich, 12: $659-68,1984$.

PAN, D. \& BASU, R.N. Mid-storage and pre-sowing seed treatments for lettuce and carrot. scientia Horticulturae, Amsterdam, 25(1): 11-9, 1985.

PANDEY, D.K. Priming induced repair in French bean seeds. Seed Science \& Technology, Zürich, 16: 527-32, 1988. 
PANDEY, D.K. Priming induced alleviation of the effects of natural ageing derived selective leakage of constituents in French bean. Seed Science Technology, Zürich, 17: $391-7,1989$.

PARMAR, M.T. \& MOORE, R.P. Carbowax 6000, mannitol and sodium chloride for simulating drought conditions in germination studies of corn (Zea mays L.) of strong and weak vigour. Agronomy Journal, Madison, 60: 192-5, 1968.

PARRISH, D.J. \& LEOPOLD, A.C. Transient changes during soybean imbibition. Plant physiology, Lancaster, 59: $1111-5,1977$.

PARRISH, D.J. \& LEOPOLD, A.C. On the mechanism of ageing in soybean seeds. Plant Physiology, Lancaster, 61(1): 365-8, 1978.

PASSAM, H.C. ; KARAVITES, P.I.; PAPANDREOU, A.A.; THANO, C.A.; GEORGHIOU, K. Osmoconditioning of seeds in relation to growth and fruit yield of aubergine, pepper, cucumber and melon in unheated greenhouse cultivation. Scientia Horticulturae, Amsterdam, 38(3/4): 207-16, 1989. 
PERL, M. Invigoration of cotton seedlings by treatments of seeds for pregermination activities. Journal of Experimental Botany, Oxford, 30(114): 183-92, 1979.

PERL, M. \& FEDER, $Z$. Invigoration of pepper seeds by treatments for pregermination activities. Separata de INTERNATIONAL SEED TESTING ASSOCIATION, 19., Vienna, 1980. $10 \mathrm{p}$.

PERL, M. \& FEDER, $Z$. Improved seedling development of pepper seeds (Capsicum annuum) by seed treatment for pregermination activies. Seed Science \& Technology, Zürich, 9: 655-63, 1981 .

PERRY, D.A. \& HARRISON, J.G. The deleterious effect of water and low temperature on germination of pea seed. Journal of Experimental Botany, Oxford, 21(67): 504/12, May 1970.

PESKE, S.T. \& DELOUCHE, J.C. Semeadura de soja em condições de baixa umidade do solo. Pesquisa Agropecuária Brasileira, Brasilia, 20(1): 69-85, jan. 1985 .

POLLOCK, B.M. Imbibition temperature sensitivity of lima beans seed controlled by initial seed moisture. plant Physiology, Lancaster, 44: 907-11, 1969. 
POPINIGIS, F. Fisiologia da semente. Brasilia, AGIPLAN, 1977. $289 \mathrm{p}$.

POWELL, A.A. \& HARMAN, G.E. Absence of a consistent association of changes in membranal lipids with the ageing of pea seeds. Seed Science \& Technology, Zürich, 13: 65967,1985 .

POWELL, A.A. \& MATTHEWS, S. The damaging effect of water on dry pea embryos during imbibition. Journal of Experimental Botany, Oxford, 29(112): 1215-29, 1978 .

PRISCO, J.T. \& O'LEARY, J.W. Osmotic and "toxic" effects of salinity on germination of Phaseolus vulgaris L. seeds. Turrialba, San Jose, 20(2): 177-84, 1970 .

RAO, S.C.; AKERS, S.W.; AHRING, R.M. Priming Brassica to improve emergence under different temperatures and soil moisture conditions. Crop Science, Madison, 27(5): 10503,1987

ROBERTS, E.H. Predicting the storage life of seeds. Seed Science \& Technology, Zürich, 1: 499-514, 1973. 
ROBERTS, E.H. Physiology of ageing and its aplication to drying and storage. Seed science \& Technology, Zürich, 9: $359-72,1981$.

SAHA, R. \& BASU, R.N. Maintenance of soybean seed viability by hydration-dehydration treatments. Indian Agriculturist, Calcutta, 25(4): 275-8, 1981 .

SAHA, R. \& BASU, R.N. Preconditioning soybean seed for viability maintenance by soaking-drying treatment. Seed Research, New Delhi, 10(2): 183-7, 1982.

SAHA, S.; MANDAL, A.K.; BASU, R.N. Physiology of seed invigoration in soybean (Glycine max L.). Seed science \& Technology, Zürich, 18(2): 269-76, 1990.

SALIM, M.H. \& TODD, G.W. Seed soaking as a pre-sowing, drought, hardening treatment in wheat and barley seedlings. Agronomy Journal, Madison, 60: 179-82, Mar./Apr. 1968.

SALISBURY, F.B. \& ROSS, C.W. Plant physiology. 3.ed. Belmonte, Wadworth, 1985. 540p. 
SAVINO, G.; HAIGH, P.M.; DE LEO, P. Effects of presoaking upon seed vigour and viability during storage. Seed Science \& Technology, Zürich, 7: 57-65, 1979.

SENARATNA, T.; MCKERSIE, B.D.; STINSON, R.H. Antioxidant levels in germinating soybean seed axes in relation to free radical and dehydration tolerance. Plant Physiology, Lancaster, 78(1): 168-71, Jan. 1985 .

SHANNON, I.C. A procedure for the extraction and fractionation of carbohydrates from immature Zea mays kernels. Purdue University Res. Bul1, p.842-80, 1963.

SHARMA, K.; SINGH, G.; SHARMA, R.; SHARMA, H.L. Biochemical changes in groundnut seed during germination under water stress conditions. Annals of Biology, Ludhiana, 5(2): 123-7, 1989. Apud Seed Abstracts, Wallingford, 13(5): 182, May 1990. (Resumo).

SHARMA, M.L. Simulation of drought and its effect on germination of five pasture species. Agronomy Journal, Madison, 65: 982-7, 1973 . 
SHIOGA, P.S. Controle da hidratação e desempenho das sementes de feijão (Phaseolus vulgaris L.). Piracicaba, 1990. 106p. (Mestrado - Escola Superior de Agricultura "Luiz de Queiroz"/USP).

SILVA, W.R. Relações entre disponibilidade de água, tratamento fungicida e germinação de sementes de milho (Zea mays L.). Piracicaba, 1989. 113p. (Doutorado Escola Superior de Agricultura "Luiz de Queiroz"/USP).

SIMON, E.W. Phospholipids and plant membrane permeability. New Phytologist, Cambridge, 73: 377-420, 1974.

SIMON, E.W. Early events in germination. In: MURRAY, D.R., ed. Seed physiology. London, Academic Press, 1984. v.2, cap. 3, p.77-115.

SIMON, E.W. \& MILLS, L.K. Imbibition, leakage and membranes. In: NOZZOLILlo, C.; LEA, P.J.; LOEWIS, F.A. Mobilization of reserves in germination, recent advances in phytochemistry. New York, Plenum Press, 1983. v.17, cap. 2, p.9-27.

SIMON, E.W. \& RAJA HARUN, R.M. Leakage during imbibition. Journal of Experimental Botany, Oxford, 23(77): 1076-85, Nov. 1972 . 
SINGER, S.J. \& NICOLSON, G.L. The fluid mosaic model of the structure of cell membranes. Science, New York, 175: 720$31, \mathrm{Feb}, 1972$.

STAZIONE SPERIMENTALE PER LE INDUSTRIE DEGLI OLI E DEI GRASSI. Norme italiane per il controllo dei grassi e derivati (NGD). 3.ed. Milano, sSOG, 1976.

STEUTER, A.A. ; MOZAFAR, A.; GOODIN, J.R. Water potential of aqueous polyethylene glycol. Plant Physiology, Lancaster, $67(1): 64-7,1981$.

SUTCLIFFE, J.F. As plantas e a água. 2.ed. São Paulo, EPU, 1980. 126p. (Temas de Biologia, 23).

TARQUIS, A.M. \& BRADFORD, K.J. Prehydration and priming treatments that advance germination also increase the rate of deterioration of lettuce seeds. Journal of Experimental Botany, Oxford, 43(248): 307-17, 1992.

TILDEN, R.L. \& WEST, S.H. Reversal of the effects of aging in soybean seeds. Plant Physiology, Lancaster, 77:584-6, 1985 . 
TOLEDO, F.F. \& MARCOS FILHO, J. Manual das sementes: tecnologia da produção. São Paulo, Ed. Agronômica Ceres, 1977. 224p.

VALDES, V.M.; BRADFORD, K.J.; MAYBERRY, K.S. Alleviation of thermodormancy in coated lettuce seeds by seed priming. HortScience, Alexandria, 20(6): 1112-4, 1985 .

VAN ONCKELEN, H.A.; VERBEEK, R.; KHAN, A.A. Relationship of ribonucleic acid metabolism in embryo and aleurone to $\alpha$ amylase synthesis in barley. Plant Physiology, Lancaster, 53: $562-8,1974$.

VILLIERS, T.A. Seed aging: chromossome stability and extended viability of seeds stored fully imbibed. plant Physiology, Lancaster, 53: 875-8, 1974.

VILLIERS, T.A. \& EDGCUMBE, D.J. On the cause of seed deterioration in dry storage. Seed Science \& Technology, Zürich, 3: 761-74, 1975.

WANG, $X$. \& ZHAO, Z.Y. Studies on changes in vigour of soyabean seeds in storage and effect of PEG. Journal of Shenyang Agricultural University, Lianing, 21(3): 207-13, 1990. Apud Seed Abstracts, Wallingford, 14(10): 422, oct. 1991. (Resumo). 
WARD, F.H. \& POWELL, A.A. Evidence for repair processes in onion seeds during storage at high seed moisture contents. Journal of Experimental Botany, Oxford, 34(140): 277-82, Mar. 1983.

WEBSTER, B.D. \& LEOPOLD, A.C. The ultrastructure of dry and imbibed cotyledons of soybean. American Journal of Botany, Columbus, 64(10): 1286-93, 1977 .

WILSON Jr., D.O. \& MCDONALD Jr., M.B. The lipid peroxidation model of seed ageing. Seed Science \& Technology, Zürich, $14: 269-300,1986$.

WOODSTOCK, L.w. Physiological and biochemical tests for seed vigor. Seed Science \& Technology, Zürich, 1: 127-57, 1973.

WOODSTOCK, L.W. \& TAO, K.L.J. Prevention of imbibitional injury in low vigor soybean embryonic axes by osmotic control of water uptake. Physiologia plantarum, Copenhagen, 51(1): 133-9, 1981 . 
WOODSTOCK, L.W. \& TAYLORSON, R.B. Soaking injury and its reversal with polyethylene glycol in relation to respiratory metabolism in high and low vigor soybean seeds. Physiologia plantarum, Copenhagen, 53(3): 263-8, Nov . 1981.

YOUNG, J.A.; EVANS, R.A.; ROUNDY, B.; CLUFF, G. Moisture stress and seed germination. Oakland, Departament of Agriculture, 1983. 41p. (Agricultural Reviews and Manuals, 36).

ZONTA, E.P.; MACHADO, A.D.; SILVEIRA JÚNIOR, P. Sistema da Análise Estatística para Microcomputadores - SANEST. Pelotas, 1984 . 